Universidade de Brasilia - UnB

Faculdade de Tecnologia - FT

Departamento de Engenharia Elétrica - ENE

\title{
ESTUDO DE SISTEMAS \\ FOTOVOLTAICOS \\ DE PEQUENO PORTE
}

Projeto Final de Graduação

Carolina Machado

Orientador: Marco Aurélio Gonçalves de Oliveira 


\section{Brasília/DF - Abril de 2002}




\section{AGRADECIMENTOS}

Ao Marco Aurélio, por sua orientação, incentivo e apoio durante estes meses de trabalho.

A todos do GAT que, com sua imensa atenção, ajudaram na execução deste projeto. Muito obrigada!

Ao Ministério de Minas e Energia, que doou o sistema solar fotovoltaico instalado nas dependências do Departamento de Engenharia Elétrica.

A todos que, direta ou indiretamente, me apoiaram durante estes longos meses de trabalho. Obrigada pela compreensão e pela amizade! 


\section{ABREVIAÇõES}

AECl - Agência Espanhola de Cooperação Internacional

ANEEL - Agência Nacional de Energia Elétrica

BOS - Balance of System (Balanço do Sistema)

CBEE - Centro Brasileiro de Energia Eólica

CEAL - Companhia Energética do Estado de Alagoas

CELESC - Centrais Elétricas de Santa Catarina

CEMIG - Companhia Elétrica de Minas Gerais

CENSOLAR - Centro de Estudos de Energia Solar

CEPEL - Centro de Pesquisas em Energia Elétrica

CESP - Companhia Elétrica de São Paulo

CNPE - Conselho Nacional de Políticas Energéticas

COELCE - Companhia Elétrica do Ceará

COELCE - Companhia Elétrica do Ceará

COPEL - Companhia Paranaense de Energia

CRESESB - Centro de Referência para Energia Solar e Eólica Sérgio de Salvo Brito

DMFC - Direct Methanol Fuel Cells

DNDE - Departamento Nacional de Desenvolvimento Energético

FIESP - Federação da Industria do Estado de São Paulo

GESTE - Grupo de Estudos Térmicos e Energéticos

Grupo FAE - Grupo de Fontes Alternativas de Energia

INPE - Instituto Nacional de Pesquisas Espaciais

IPADE - Instituto de Promoção e Apoio ao Desenvolvimento

LABSOLAR - Laboratório de Energia Solar da Universidade Federal de Santa Catarina

LACTEC - Instituto de Tecnologia para o Desenvolvimento

LVD - Low Voltage Disconnect

MCT - Ministério de Ciência e Tecnologia

MME - Ministério de Minas e Energia 
Pequeno Porte

NREL - Laboratório Americano de Energias Renováveis

OLADE - Organização Latino-americana de Energia

OMM - Organização Mundial de Meteorologia

PIER - Programa de Incentivo a Energias Renováveis

PRODEEM - Programa Nacional de Desenvolvimento Energético de Estados e Municípios

STC - Condição Padrão de Teste

UFPR - Universidade Federal do Paraná

UFRGS - Universidade Federal do Rio Grande do Sul

UFSC - Universidade Federal de Santa Catarina

WANAB - Wind Atlas for the Northest of Brazil 


\section{SímBOLOS}

a-Si - Silício amorfo

CdTe - Telureto de Cádmio

$\mathrm{CulnSe}_{2}$ - Disseleneto de Cobre e Índio

CulnGaSe $_{2}$ - Disseleneto de Cobre, Gálio e Índio

$\mathrm{CO}_{2}$ - Dióxido de Carbono

FP - Fator de Potência

$h_{P}-$ Rendimento dos painéis

$I_{M P}$ - Corrente de potência máxima

$\mathrm{I}_{\mathrm{sc}}$ - Corrente de curto circuito

mono-Si - Silício monocristalino

$\mathrm{P}_{\mathrm{M}}$ - Potência máxima

poli-Si - Silício policristalino

$\mathrm{V}_{\mathrm{MP}}$ - Tensão de potência máxima

$V_{o c}$ - Tensão de circuito aberto

Wh - Unidade de energia (watt $x$ hora)

$\mathrm{Wh} / \mathrm{m}^{2}$ - Unidade de radiação

$W_{P}$ - Unidade de potência máxima entregue pelos painéis solares em condição padrão de teste 


\section{ÍNDICE}

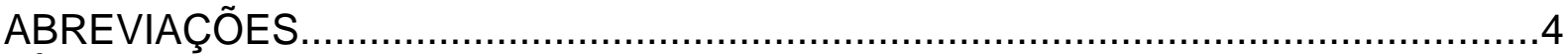

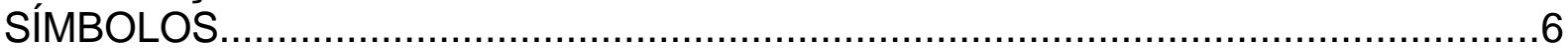

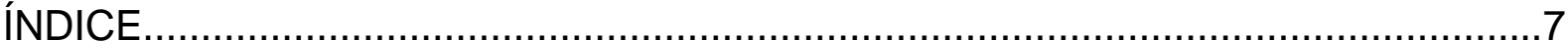

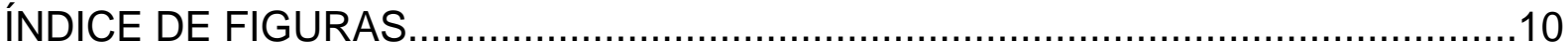

RESUMO

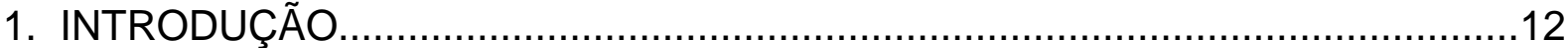

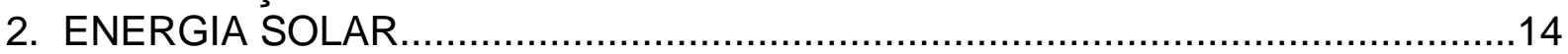

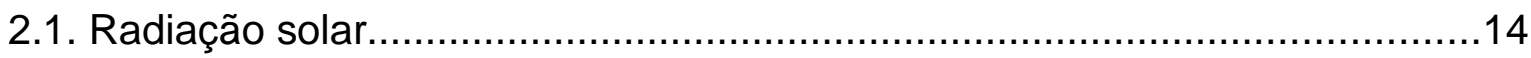

2.1.1. Captação da radiação solar...........................................................14

2.1.2. Medição da radiação solar............................................................16

2.1.2.1. Heliógrafo de Campbell-Stokes...................................................17

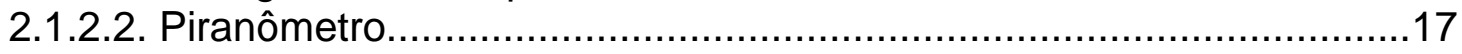

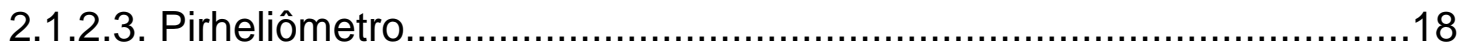

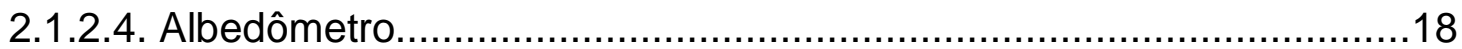

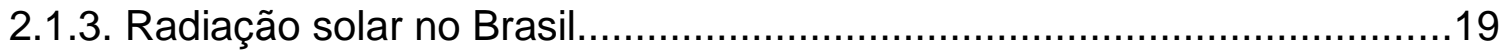

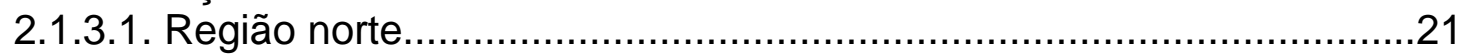

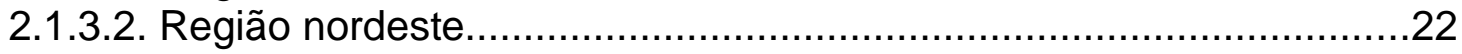

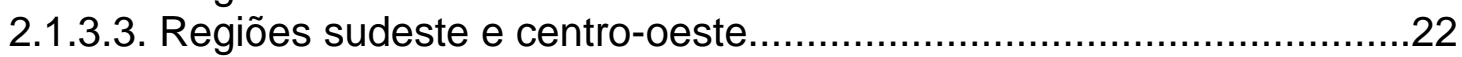

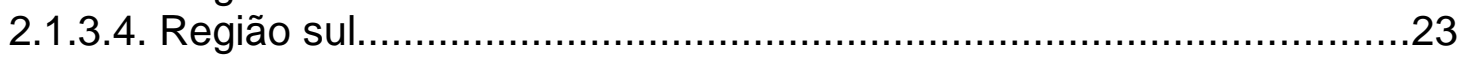

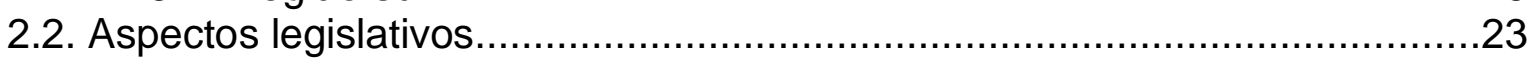

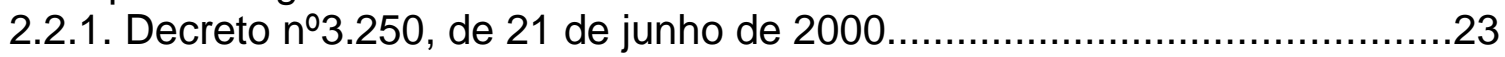

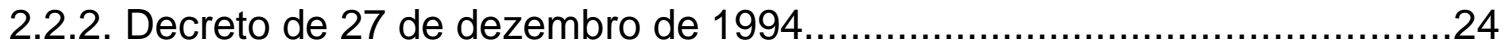

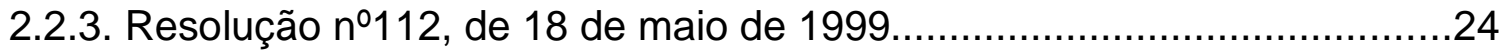

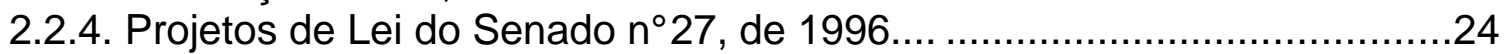

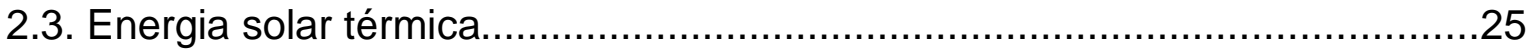

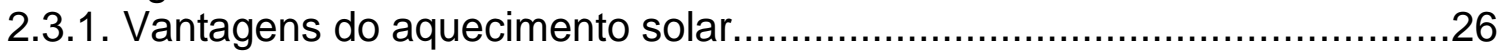

2.4. Arquitetura bioclimática - energia solar passiva.......................................27

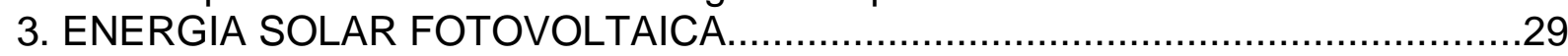

3.1. Tecnologia de fabricação de células fotovoltaicas......................................29

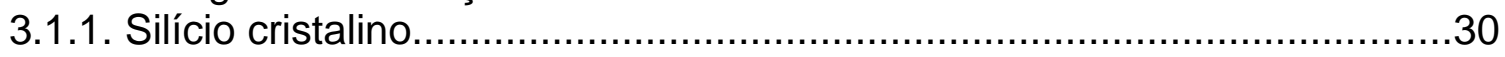

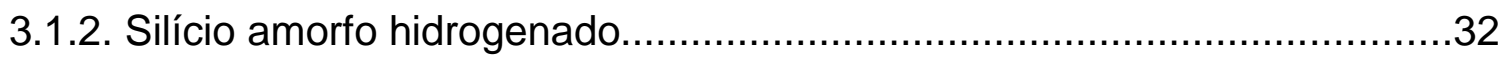

3.1.3. Telureto de cádmio e disseleneto de cobre e índio.................................33

3.2. Módulos solares fotovoltaicos..............................................................33

3.2.1. Características elétricas dos módulos..............................................34

3.2.2. Fatores que influenciam nas características elétricas dos módulos..........35

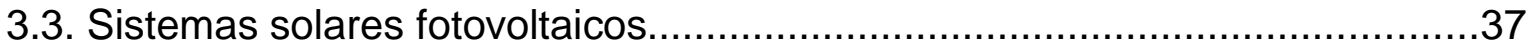

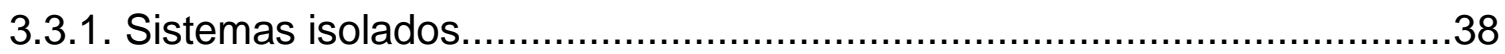

3.3.1.1. Cargas em corrente contínua sem armazenamento.........................38

3.3.1.2. Cargas em corrente contínua com armazenamento..........................39

3.3.1.3. Cargas em corrente alternada sem armazenamento.........................39

3.3.1.4. Cargas em corrente alternada com armazenamento.........................39

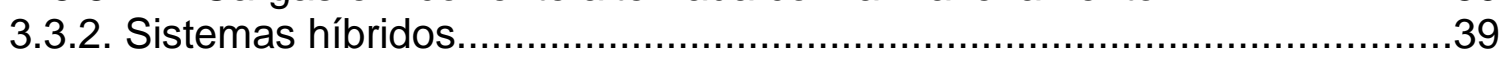


3.3.3. Sistemas interligados à rede elétrica................................................ 40

3.3.3.1. Sistemas Residenciais.........................................................41

3.3.3.2. Sistemas de grande porte ....................................................42

3.4. Principais sistemas solares fotovoltaicos instalados no Brasil.....................43

3.4.1. Eletrificação fotovoltaica na comunidade de Boa Sorte (Correguinho/MS)

.

.

3.4.4. Sistema de eletrificação residencial em Pernambuco.............................45

3.4.5. Sistema híbrido da Vila de Campinas (Manacapuru/AM) ........................46

3.4.6. Sistemas solares conectados à rede elétrica pública............................46

3.5. Considerações sobre a utilização de energia solar fotovoltaica....................47

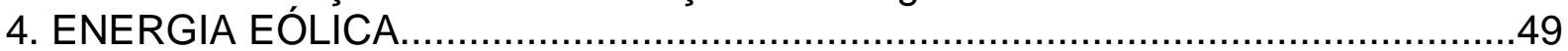

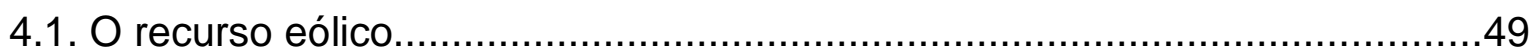

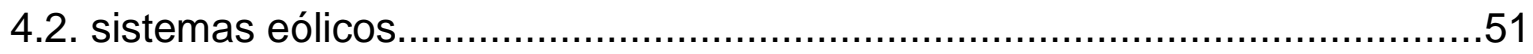

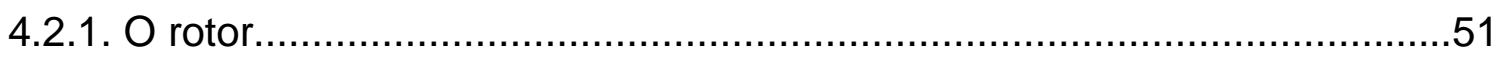

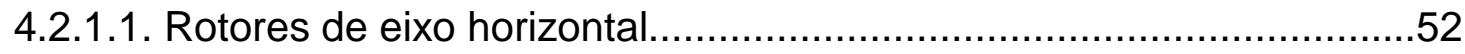

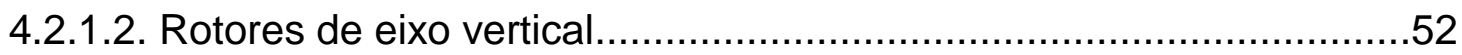

4.2.2. Transmissão e caixa multiplicadora.....................................................53

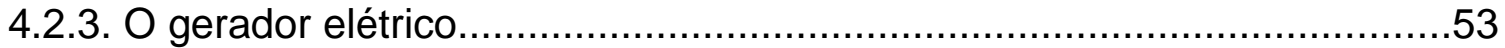

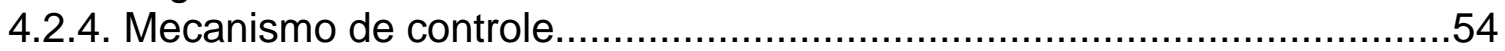

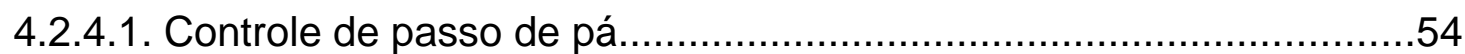

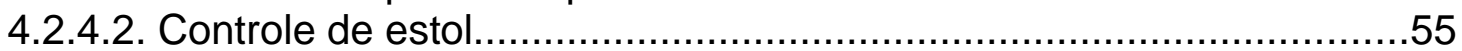

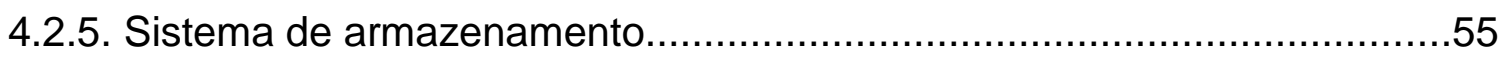

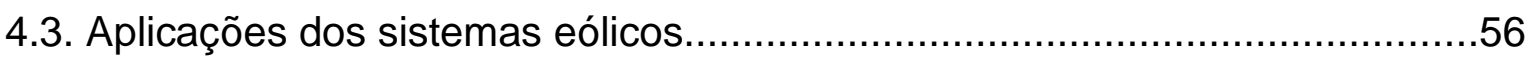

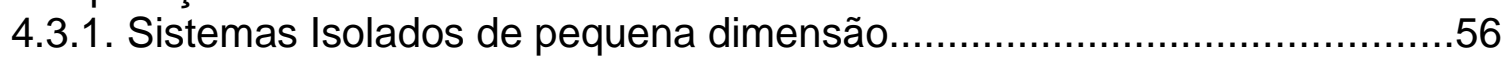

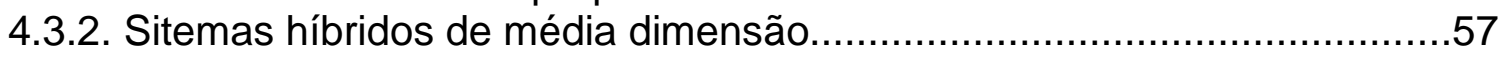

4.3.3. Sistemas de grande dimensão interligados à rede elétrica.....................58

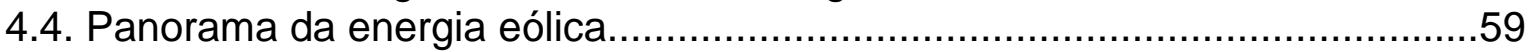

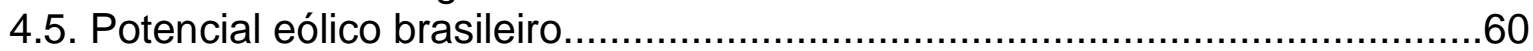

4.6. Projetos de Energia Eólica no Brasil.........................................................61

4.6.1. Fazenda eólica em Minas Gerais......................................................62

4.6.2. Fazenda eólica de Mucuripe (Fortaleza/CE) ...................................62

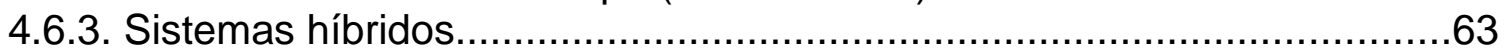

4.6.3.1. Sistema híbrido para testes do CBEE.......................................63

4.6.3.2. Sistema híbrido para Joanes...................................................63

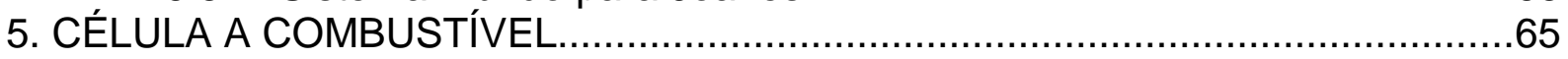

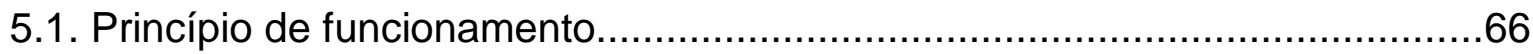

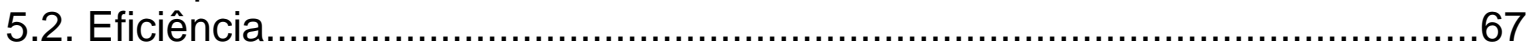

5.3. Vantagens e limitações das células a combustível....................................68

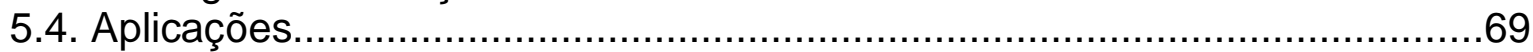

6. DIMENSIONAMENTO DE UM SISTEMA FOTOVOLTAICO DE PEQUENO

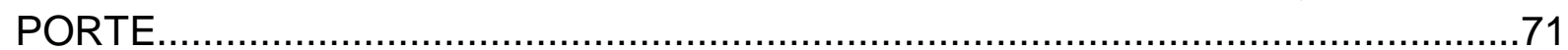

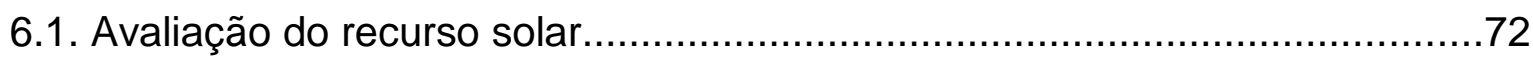

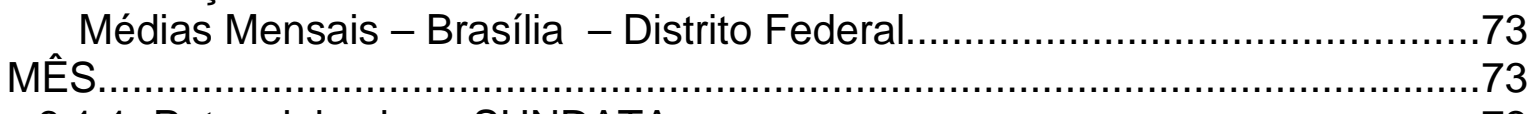

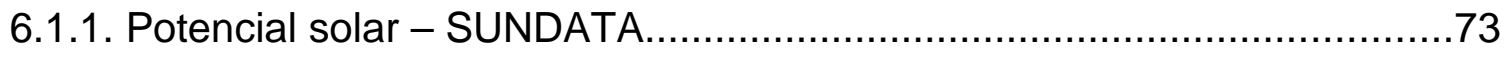


MÊS .74

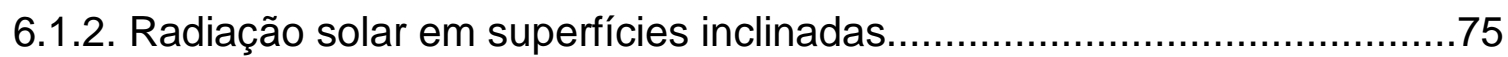

6.2. Avaliação do comportamento das cargas........................................... 78

6.3. Dimensionamento do sistema de armazenamento...................................79

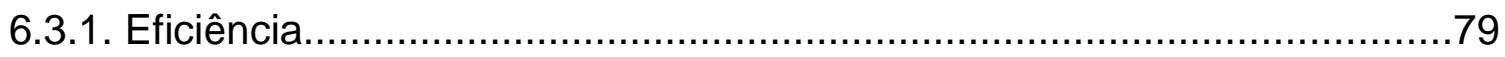

6.3.2. Máxima profundidade de descarga................................................ 79

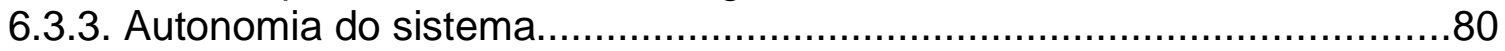

6.4. Dimensionamento da geração fotovoltaica......................................... 80

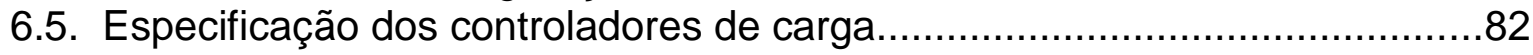

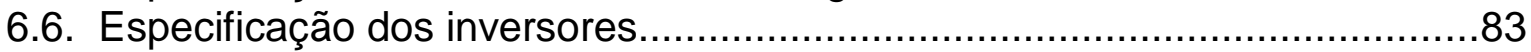

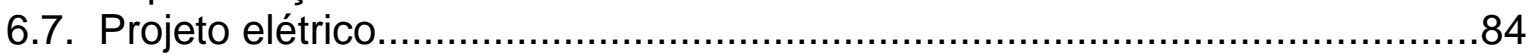

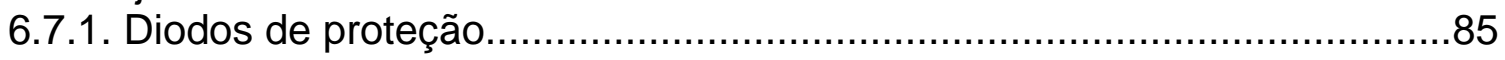

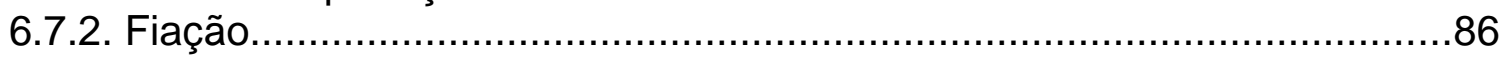

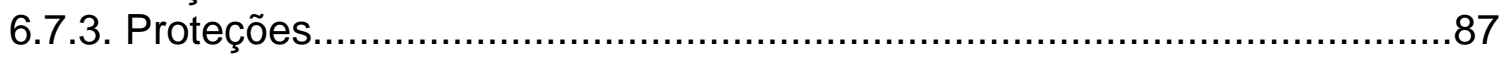

6.8. Planilhas de dimensionamento de um sistema de iluminação fotovoltaico....88

6.8.1. Cálculo do consumo de cargas.....................................................88

6.8.2. Determinação da corrente e do ângulo de inclinação do arranjo...............90

6.8.3. Dimensionamento do banco de baterias..........................................90

6.8.4. Dimensionamento do arranjo fotovoltaico...........................................91

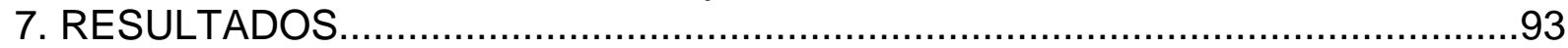

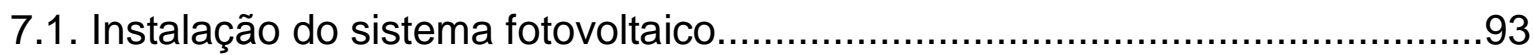

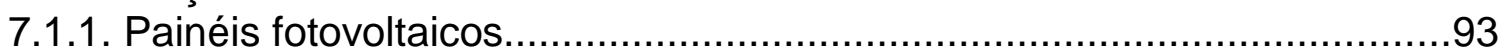

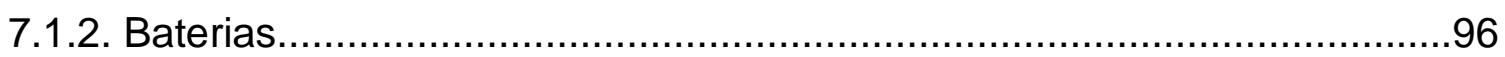

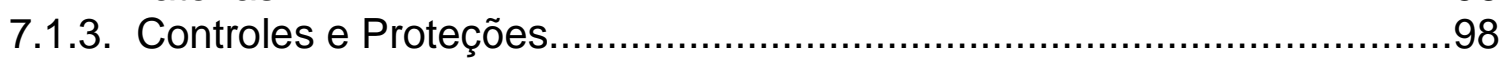

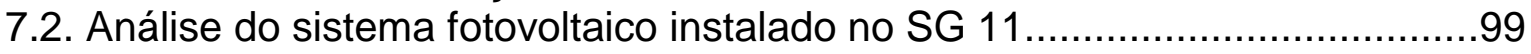

7.2.1. Eficiência dos sistemas fotovoltaicos......................................... 101

7.1.2. Desempenho do sistema fotovoltaico..............................................103

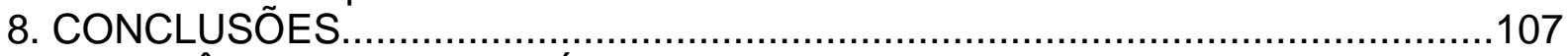

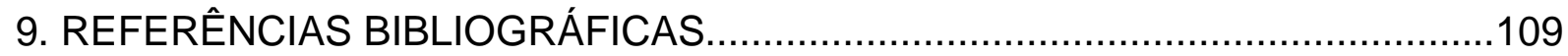

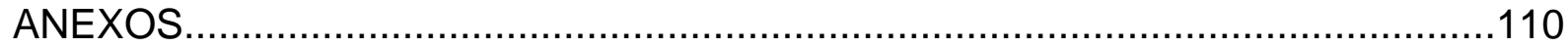




\section{ÍNDICE DE FIGURAS}

Figura 2.1 - Componentes da radiação solar que atinge a superfície terrestre.......15

(Fonte: Energia Solar - Princípios e Aplicações) ................................................15

Figura 2.2 - Trajetória dos raios solares na atmosfera. ......................................... 16

(Fonte: Manual de Engenharia para Sistemas Fotovoltaicos) ...............................16

Figura 2.3 - Heliógrafo.............................................................................

(Fonte: http://www.inmet.gov.br/informa/instrum.htm) ..................................17

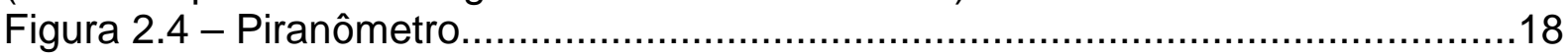

(Fonte: http://www.inmet.gov.br/informa/instrum.htm).................................18

Figura 3.1 - Parâmetros de Potência Máxima de uma Célula de Silício Cristalino...35

(Fonte: CRESESB - "Energia Solar - Princípios e Aplicações")...........................35

Figura 3.2 - Efeito causado pela variação de intensidade da luz na curva

característica IxV para um módulo fotovoltaico .............................................36

(Fonte: CRESESB - "Energia Solar - Princípios e Aplicações")...........................36

Figura 3.3 - Efeito causado pela temperatura da célula na curva característica IxV

(para $1000 \mathrm{~W} / \mathrm{m} 2$ ) em um módulo fotovoltaico de silício cristalino...........................37

(Fonte: CRESESB - "Energia Solar - Princípios e Aplicações")...........................37

Figura 3.4 - Exemplo de Sistema Híbrido...................................................40

(Fonte: CRESESB - "Energia Solar - Princípios e Aplicações")..........................40

Figura 5.1 - Funcionamento da Célula a Combustível........................................67

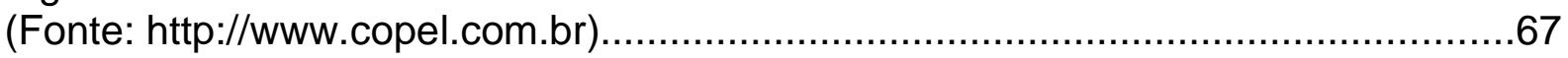

Figura 6.1 - Exemplo de configuração de um sistema fotovoltaico de pequeno porte

Figura 6.3 - Gráfico de radiação solar ao longo de um ano para diferentes valores de

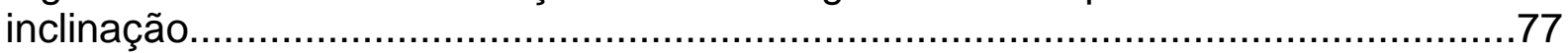

Figura 6.4 - Alguns painéis Kyocera e Siemens disponíveis comercialmente..........81

(Fonte: "Energia Solar - Princípios e Aplicações") ........................................... 81

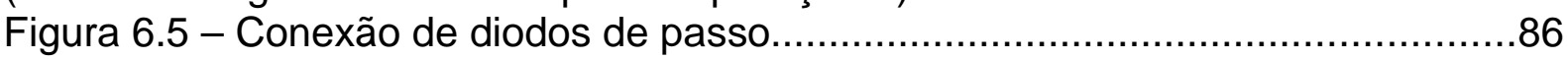

Figura 7.1 - Painéis solares fotovoltaicos instalados no telhado do SG $11 \ldots \ldots \ldots \ldots . . .95$

Figura 7.2 - Conexão de baterias em paralelo............................................97

Figura 7.3 - Baterias que compõem o sistema fotovoltaico instalado no SG $11 \ldots \ldots .97$

Figura 7.4 - Controlador de carga e inversor do sistema fotovoltaico do SG $11 \ldots . . .99$

Figura 7.5 - Diagrama das ligações dos relés, reatores e do timer.........................100

Figura 7.6 - Gráfico de carga das baterias.................................................... 103

Figura 7.7 - Gráfico de carga das baterias........................................................103

Figura 7.8 - Gráfico de descarga das baterias................................................104

Figura 7.9 - Gráfico de descarga das baterias.............................................104

Figura 7.10 - Gráfico correspondente ao tempo de funcionamento......................105

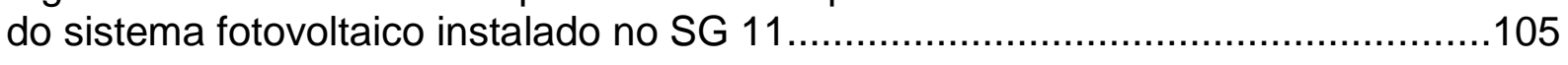




\section{RESUMO}

Este trabalho apresenta um estudo sobre as principais fontes de energia renováveis que estão em desenvolvimento e que vêm sendo utilizadas para geração de energia elétrica, principalmente no Brasil.

São descritas três importantes fontes alternativas: a Energia Solar, a Energia Eólica e a Célula a Combustível. A energia solar e a energia eólica são fontes que vêm sendo estudadas há alguns anos, e que após a crise do petróleo ocorrida na década de 70, apresentaram crescimento significativo em sua utilização. Tais fontes estão sendo aplicadas em diversas localidades do Brasil, principalmente nas localidades onde a rede convencional de energia elétrica não supre o fornecimento de energia. A célula a combustível é uma tecnologia que ainda vem sendo desenvolvida e cujas aplicações ainda não estão sendo utilizadas em larga escala.

São apresentados, também, os procedimentos necessários para o dimensionamento de um sistema solar fotovoltaico de pequeno porte. Tais procedimentos foram utilizados para dimensionar o sistema instalado no prédio do SG 11 para o suprimento de energia elétrica de luminárias presentes em seu interior. Este sistema, uma doação do Ministério de Minas e Energia, através do Programa de Desenvolvimento Energético de Estados e Municípios - PRODEEM - foi instalado para que se pudesse observar o comportamento dos diversos componentes que o integram e do seu desempenho geral, a fim de comprovar a metodologia de dimensionamento de sistemas fotovoltaicos apresentada. 


\section{INTRODUÇÃO}

O aproveitamento da energia gerada pelo Sol, em relação aos níveis atuais de consumo energético, é considerado inesgotável, tanto como fonte de calor quanto como fonte de energia elétrica. Em termos energéticos, o Sol é responsável pela maioria das fontes de energia existentes mundialmente: a partir da energia gerada pelo Sol ocorre a evaporação que é responsável pelo ciclo das águas, possibilitando o represamento dos rios e a conseqüente geração hidroelétrica, representante de mais de $90 \%$ da energia elétrica produzida no Brasil; a radiação solar também é responsável pela circulação atmosférica em larga escala, que gera os ventos que são aproveitados pela energia eólica.

Os problemas de esgotabilidade do petróleo - o combustível energético mais utilizável - e a preocupação global com o aumento da concentração de dióxido de carbono $\left(\mathrm{CO}_{2}\right)$ na atmosfera terrestre são os principais fatores que impulsionam a utilização de fontes alternativas de energia por parte dos países desenvolvidos. Neste contexto, energia solar, energia eólica, dentre outras, disputam entre si e com as tecnologias já utilizadas em larga escala uma maior atenção, no sentido de aumentar a escala de produção e, consequentemente, tornar os preços mais competitivos para a energia gerada.

A tecnologia de células a combustível, ainda em fase de desenvolvimento, também pode ser considerada uma fonte alternativa para geração de energia e que futuramente se juntará às tecnologias já existentes.

Dentro da matriz energética brasileira, o crescimento da utilização de energias alternativas deve-se ao caráter não renovável dos combustíveis fósseis e ao esgotamento de novos potenciais para geração de energia a partir de fontes renováveis. O que resulta no aumento de preço das formas tradicionais de energia, tornando competitivo o uso de energias alternativas em diversas situações.

Um outro fator que impulsiona o desenvolvimento das fontes renováveis de energia é o atendimento de comunidades isoladas. No Brasil, cerca de $15 \%$ da população não possui acesso à energia elétrica, e esta parcela da população vive 
Pequeno Porte

em regiões onde o atendimento por meio da expansão da rede elétrica convencional é inviável economicamente, principalmente no Centro-Oeste, Nordeste e Norte, segundo informações do Centro de Referência para Energia Solar e Eólica Sérgio de Salvo Brito - CRESESB.

Desde a realização da Conferência das Nações Unidas sobre Meio Ambiente e Desenvolvimento - Rio 92 foram implantados mais de $250 \mathrm{~kW}$ de sistemas fotovoltaicos e 2,3 MW de sistemas eólicos no Brasil, a partir de doações internacionais e com o apoio de Centros de Pesquisa, Concessionárias de Energia e Governos Estaduais que garantiram a contrapartida para montagem, instalação e aquisição de equipamentos periféricos. 
Estudo de Sistemas Fotovoltaicos de

\section{ENERGIA SOLAR}

A Terra recebe anualmente $1,5 \times 10^{18} \mathrm{kWh}$ de energia solar, o que corresponde a 10.000 vezes o consumo mundial de energia no mesmo período. $\mathrm{O}$ Brasil, por ser um país de dimensões continentais e situar-se quase que inteiramente em uma região tropical, possui um dos maiores potenciais do mundo para a utilização da energia solar como forma alternativa de energia.

As tecnologias que vêm sendo utilizadas para o aproveitamento direto da energia solar são a conversão fotovoltaica, a conversão térmica e a arquitetura bioclimática - aquecimento solar passivo.

\subsection{Radiação solar}

O conhecimento da radiação solar incidente na superfície terrestre é de extrema importância, tanto para a observação das mudanças climáticas ocorridas no mundo quanto para a utilização racional da energia solar.

\subsubsection{Captação da radiação solar}

A radiação solar que atinge o topo da atmosfera terrestre provém da região da fotosfera solar, uma camada tênue com cerca de $300 \mathrm{~km}$ de espessura. Esta radiação, devido à influência das camadas externas do Sol, não é regular. Apesar disto, define-se um valor médio para o nível de radiação solar que incide normal a uma superfície situada no topo da atmosfera que, segundo dados da Organização Mundial de Meteorologia (OMM), é de $1367 \mathrm{~W} / \mathrm{m}^{2}$.

Devido aos fenômenos de reflexão e absorção dos raios solares pela atmosfera, apenas uma fração de toda a radiação solar que chega ao topo da atmosfera atinge a superfície terrestre. A fração que atinge o solo é constituída por uma componente direta (ou de feixe) e por uma componente difusa. A componente direta é composta de raios paralelos vindos diretamente do Sol e a componente difusa consiste em raios espalhados pela atmosfera terrestre e também refletidos 
Pequeno Porte

pelas nuvens. Se a superfície receptora estiver inclinada com relação à horizontal, haverá uma terceira componente refletida pelo ambiente do entorno (solo, vegetação, obstáculos), cujo coeficiente de reflexão é denominado albedo. A figura 2.1 ilustra as diferentes componentes da radiação solar que atinge a superfície terrestre.

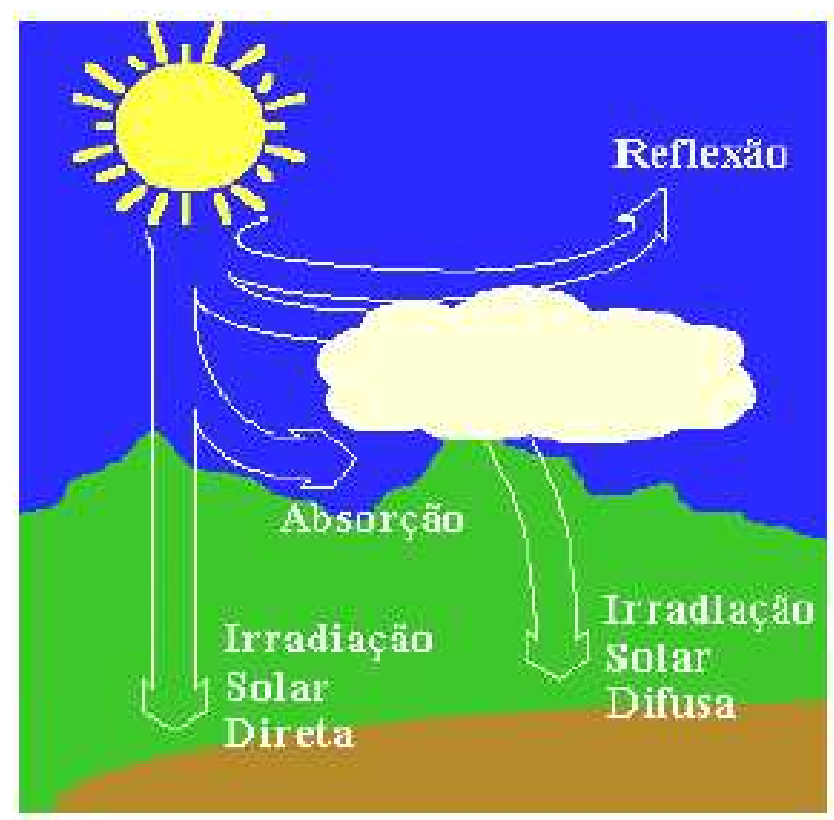

Figura 2.1 - Componentes da radiação solar que atinge a superfície terrestre (Fonte: Energia Solar - Princípios e Aplicações)

Antes de atingir o solo, as características da radiação solar (intensidade, distribuição espectral e angular) são afetadas por interações com a atmosfera, devido aos efeitos de absorção e espalhamento. Estas modificações dependem da espessura da camada atmosférica, também identificada por um coeficiente denominado "Massa de Ar"; do ângulo formado entre os raios solares e a vertical (ângulo zenital); da distância Terra-Sol e das condições atmosféricas e meteorológicas, conforme a figura 2.2. 


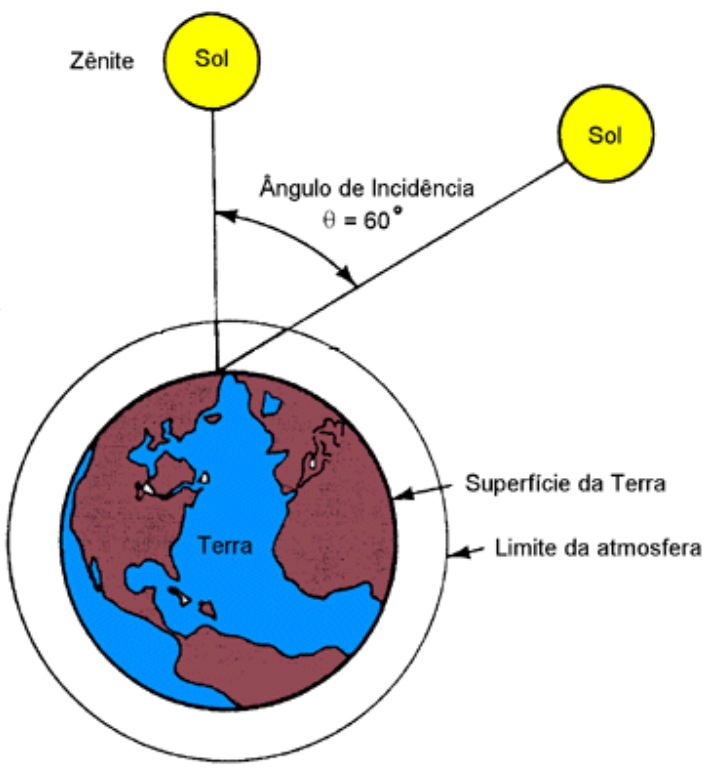

Figura 2.2 - Trajetória dos raios solares na atmosfera.

(Fonte: Manual de Engenharia para Sistemas Fotovoltaicos)

No hemisfério sul, para maximizar a captação da energia solar ao longo do ano, o sistema de captação solar fixo deve estar orientado para o Norte Geográfico e posicionado em inclinação com relação à horizontal de um ângulo próximo ao da latitude do local. Próximo ao Equador, o melhor posicionamento é o horizontal. A orientação para a direção Norte Geográfico pode ser feita através de uma bússola que indica o Norte Magnético e através do Mapa de declinação magnética e variação anual do Observatório Nacional que determina a correção angular necessária - ângulo que deve ser adicionado à direção apontada pela bússola no sentido horário.

\subsubsection{Medição da radiação solar}

A medição da radiação solar na superfície da terra, tanto da componente direta quanto da componente difusa, é o fator importante para o estudo de influências das condições climáticas e atmosféricas. Com o estudo destas medidas são projetadas e implementadas as instalações de sistemas térmicos e fotovoltaicos em uma determinada região, a fim de garantir o máximo aproveitamento ao longo do ano, já que existem variações de intensidade de radiação solar. 
Os principais parâmetros considerados nos estudos de radiação solar são:

- A duração da insolação;

- A latitude;

- A altitude;

- O relevo;

- A cobertura de nuvens;

- A quantidade de sombra.

Alguns dos principais instrumentos para medição da radiação são descritos a seguir:

\subsubsection{Heliógrafo de Campbell-Stokes}

Este instrumento mede o número de horas de insolação. A radiação solar é focalizada por uma esfera de cristal com $10 \mathrm{~cm}$ de diâmetro sobre uma fita que, pela ação da radiação, é enegrecida. O comprimento desta fita exposta à radiação solar mede o número de horas de insolação.

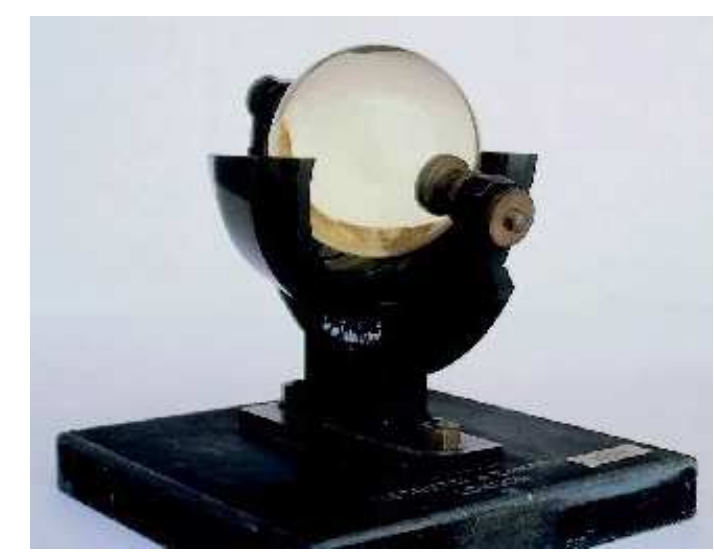

Figura 2.3 - Heliógrafo

(Fonte: http://www.inmet.gov.br/informa/instrum.htm)

\subsubsection{Piranômetro}

Utilizado para medir a radiação solar global, este instrumento caracteriza-se pelo uso de uma termopilha que mede a diferença de temperatura entre duas superfícies, uma pintada de preto e outra pintada de branco igualmente iluminadas. 
Pequeno Porte

A expansão sofrida pelas superfícies provoca um diferencial de potencial que, ao ser medido, mostra o valor instantâneo da energia solar.

Um outro modelo de piranômetro utiliza uma célula fotovoltaica de silício monocristalino para coletar medidas solarimétrias. Pelas características da célula fotovoltaica, este aparelho apresenta limitações já que apresenta sensibilidade em apenas $60 \%$ da radiação solar incidente.

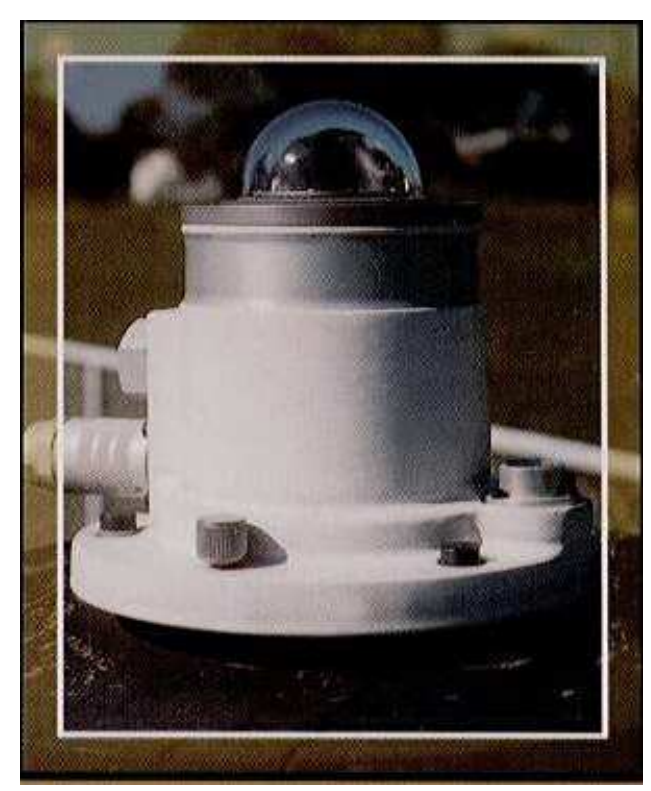

Figura 2.4 - Piranômetro

(Fonte: http://www.inmet.gov.br/informa/instrum.htm)

\subsubsection{Pirheliômetro}

O pirheliômetro mede a radiação solar direta, além de ser utilizado como referência na calibração de piranômetros. Caracteriza-se por apresentar uma pequena abertura de forma a visualizar apenas o disco solar e a região vizinha denominada circunsolar. É um instrumento que necessita dispor de um dispositivo que faça o rastreamento do movimento solar.

\subsubsection{Albedômetro}

Utilizado para medir a radiação solar global e a radiação refletida, dando como resposta o valor do albedo - medida que indica o quanto o meio (vegetação, prédios, montanhas, neve, etc.) reflete da radiação solar que incide sobre ele. Seu 
valor é obtido dividindo-se o total de radiação solar refletida pelo meio pela radiação solar global que incide no local.

\subsubsection{Radiação solar no Brasil}

Afirma-se que, no Brasil, a média mensal de energia solar incidente diariamente sobre cada metro quadrado varia entre $25 \mathrm{MWh}$ e $75 \mathrm{MWh}$, dependendo da localidade e da época do ano. Essa energia depende, basicamente, das modulações introduzidas pela atmosfera no fluxo de radiação incidente no topo da atmosfera, sendo o principal elemento de modulação a cobertura de nuvens que atua no sentido de causar um resfriamento da atmosfera. O que quantifica o efeito das nuvens é a diferença entre os fluxos de retorno da radiação ao espaço com ou sem a presença das nuvens.

O vapor d'água, os aerossóis atmosféricos resultantes da queima de combustível fóssil por veículos e por resíduos industriais nos centros urbanos e da queima da biomassa das florestas, os gases que compõem a atmosfera (ozônio, óxidos de carbono, entre outros), a topografia e o albedo (razão entre radiação incidente e radiação refletida) também são fatores que exercem influência na radiação solar. Quanto maior a disponibilidade de aerossóis na atmosfera, maior deve ser a formação de nuvens e menor a radiação solar direta que atinge a superfície. Além disso, na época das queimadas, são apresentados os maiores desvios entre os dados de radiação obtidos em superfície e os medidos por modelos que empregam dados de satélite.

A região dos trópicos é o local onde se encontra o maior potencial solar energético devido às baixas latitudes e também onde se situam os mais importantes níveis de cobertura de nuvens.

Pelo fato de o clima variar com o tempo, o levantamento da radiação solar incidente demanda estudos de longa duração para que se possa obter uma base de dados criteriosa. O tempo mínimo dever ser de cinco anos, que é o tempo de duração de meio ciclo solar principal, porém existe a necessidade de realizar estudos por períodos de tempo mais longos, dez anos, por exemplo. 
Os modelos de estudo de levantamento dos recursos energéticos solares existentes atualmente são baseados em dados de satélites geoestacionários e permitem fazer um mapeamento criterioso da radiação solar em regiões, qualquer que seja a escala. Estes modelos apresentam custos relativamente baixos, menos de US $\$ 2,00$ por $\mathrm{km}^{2}$, e níveis de confiabilidade iguais ou superiores aos obtidos pelo mapeamento realizado com interpolação de dados obtidos por estações radiométricas. Entre os parâmetros de entrada desses modelos estão as variações climáticas que podem definir as características da atmosfera e o nível de atenuação e espalhamento da luz solar que a atravessa.

Os principais projetos de mapeamento do recurso solar realizados no Brasil originaram dois atlas, que fornecem subsídios ao planejamento energético a curto e médio prazo, apesar de ser importante que o mapeamento deste recurso energético esteja em constante atualização:

- O Atlas de Irradiação Solar desenvolvido pelo Laboratório de Energia Solar da Universidade Federal de Santa Catarina (LABSOLAR) em parceria com o Instituto Nacional de Pesquisas Espaciais (INPE);

- O Atlas de Irradiação Solar desenvolvido pela Universidade Federal de Pernambuco juntamente com o Centro de Pesquisas de Energia Elétrica (CEPEL).

O LABSOLAR publicou o Atlas de Irradiação Solar do Brasil utilizando um método físico para estimar a radiação solar na superfície. Foi utilizado um algoritmo, denominado BRAZILSR, que estima a radiação solar incidente na superfície a partir dos dados de cobertura efetiva de nuvens obtidos pelo satélite geoestacionário GOES-8 e a partir das transmitâncias nas condições atmosféricas de céu claro e céu nublado.

Este modelo utiliza como parâmetros de entrada as coberturas efetivas de nuvens, além de informações sobre os constituintes da atmosfera (temperatura e umidade relativa), do albedo de superfície e da altitude, sendo as nuvens o principal fator de modulação do fluxo de radiação atmosférica. A validação do modelo foi realizada comparando-se suas estimativas dados de piranômetros disponíveis no território nacional. 
Este atlas publicou os Mapas de Irradiação Mensal e de Variabilidade Diária por Mês, obtidos dos dados de irradiação agrupados mês a mês no período de 1995 a 1998. No Anexo $\boldsymbol{A}$ estão alguns destes mapas, que apresentam os valores de irradiação na unidade $\mathrm{Wh} / \mathrm{m}^{2}$ - unidade mais usual.

As imagens de irradiação foram obtidas por interpolação, a partir de uma matriz de estimativas geradas pelo modelo, com resolução de $0,5^{\circ}$ de latitude por $0,5^{\circ}$ de longitude, o que corresponde a um setor de, aproximadamente, $50 \mathrm{~km}$ por 50 km no Equador. Os mapas de variabilidade diária no mês foram gerados calculandose os desvios padrão em cada setor de $0,5^{\circ}$ por $0,5^{\circ}$ durante o respectivo mês. Este desvio, normalizado pela média mensal em cada setor foi denominado de variabilidade e é fornecido em valores percentuais.

Os dados apresentados neste atlas servem de referência atual para consulta das médias diárias e mensais para qualquer ponto do território nacional, mesmo que suas estatísticas ainda não estejam estabilizadas. São necessários, no mínimo, quatorze anos para estabilização das estatísticas climáticas.

Em estudos realizados no Brasil foram caracterizadas as principais regiões macro-climáticas existentes.

\subsubsection{Região norte}

A região norte é caracterizada pela maior homogeneidade espacial e sazonal da temperatura e é a região de maiores índices anuais de totais pluviométricos. Os locais de precipitação abundante são aqueles que apresentam menores expectativas de disponibilidade de recurso energético solar. O noroeste da Amazônia destaca-se por ser a região de menor disponibilidade de recurso solar, exatamente onde os índices anuais de precipitação são máximos.

O verão é a estação de grande aumento de nebulosidade e de baixa irradiação na região amazônica ao sul da linha do Equador. Esta época coincide exatamente à estação chuvosa da região. Já no outono, são registradas as maiores temperaturas. Durante o inverno, as regiões do Acre, de Rondônia e de parte do Amazonas são invadidas por sistemas anticiclones, de origem nas altas latitudes, que provocam diminuição de temperatura. Na primavera, são observados os 
Pequeno Porte

maiores índices de irradiação e os menores índices de precipitação acumulada, ao mesmo tempo em que são apresentadas as menores temperaturas máximas médias. Os Mapas de Irradiação das figuras 3A e 9 A (Anexo) mostram a variação da irradiação sobre a Amazônia.

\subsubsection{Região nordeste}

A região nordeste apresenta uma grande variabilidade espacial e temporal no regime de chuvas e é onde ocorre uma grande homogeneidade sazonal e espacial de temperatura, com exceção do sul da Bahia que está sujeito a frentes frias nos meses de inverno.

O norte da região apresenta o máximo de precipitação entre os meses de fevereiro e maio, porém, segundo os dados de irradiação (Figura 7A - Anexo), é no inverno que ocorre a disponibilidade mínima do recurso solar. A região costeira, principalmente ao leste, apresenta os menores índices de irradiação solar devido ao aumento de nebulosidade e chuvas. Durante o verão, ocorre uma diminuição da irradiação na costa. A região do semi-árido apresenta uma excelente disponibilidade de irradiação solar, conforme mostra o Mapa da Irradiação Anual Típica - Figura 1A (Anexo).

O que se tem na região nordeste é a menor variabilidade da irradiação média diária, comparada às outras regiões climáticas brasileiras.

\subsubsection{Regiões sudeste e centro-oeste}

As regiões sudeste e centro-oeste, em geral, apresentam boa disponibilidade de radiação solar, exceto nas regiões litorânea e serrana. Entretanto, a variabilidade mensal da irradiação anual se mostra visível ao sul desta região devido ao efeito das estações do ano.

Tanto as precipitações como a nebulosidade distribuem-se uniformemente por toda a região, com exceção do verão, sendo os estados de Goiás e Minas Gerais aqueles que apresentam menor nebulosidade. 
Pequeno Porte

Durante os meses de inverno, o sul das regiões sudeste e centro-oeste é afetado pelas frentes frias associadas a chuvas e nebulosidades. Consequentemente, ocorre um declínio da oferta de energia solar.

\subsubsection{Região sul}

Nesta região, o efeito sazonal é bastante significativo conforme indica 0 Mapa de Variabilidade Mensal da Irradiação Anual Típica (Figura 2A - Anexo). As precipitações ocorrem, em maior escala, sobre o litoral do Paraná e o oeste de Santa Catarina e os mínimos de radiação solar se localizam sobre a região litorânea de Santa Catarina.

Por existir um balanço entre a nebulosidade na região norte no inverno e a maior duração do dia na região sul no verão, a irradiação é maior na região sul que na região norte nessas épocas opostas.

\subsection{Aspectos legislativos}

Algumas das mais importantes leis, decretos, resoluções e projetos em tramite pelo Congresso Nacional que influenciam direta ou indiretamente 0 desenvolvimento da energia solar no Brasil estão listadas a seguir.

\subsubsection{Decreto n³.250, de 21 de junho de 2000}

Este decreto dispõe sobre a estrutura e o funcionamento do Conselho Nacional de Políticas Energéticas - CNPE, um órgão responsável pela formulação de políticas e diretrizes de energia, que se destinam a:

I. Promover o aproveitamento racional dos recursos energéticos do País, em conformidade com o disposto na legislação aplicável;

II. Assegurar, o suprimento de insumos energéticos às áreas mais remotas ou de difícil acesso do País;

III. Rever periodicamente as matrizes energéticas aplicadas às diversas regiões do País, considerando as fontes convencionais e alternativas e as tecnologias disponíveis; 


\subsubsection{Decreto de 27 de dezembro de 1994}

Decreto que cria o Programa de Desenvolvimento Energético de Estados e Municípios - PRODEEM, cujos objetivos são:

I. Viabilizar a instalação de microssistemas energéticos de produção e uso locais, em comunidades carentes isoladas não servidas por rede elétrica, destinados a apoiar $\mathrm{o}$ atendimento das demandas sociais básicas;

II. Promover 0 aproveitamento das fontes de energia descentralizadas no suprimento de energéticos aos pequenos produtores, aos núcleos de colonização e às populações isoladas;

III. Complementar a oferta de energia dos sistemas convencionais com a utilização de fontes de energia renováveis descentralizadas;

IV. Promover a capacitação de recursos humanos e o desenvolvimento da tecnologia e da indústria nacionais, imprescindíveis à implantação e à continuidade operacional dos sistemas a serem implantados.

\subsubsection{Resolução n¹12, de 18 de maio de 1999}

Estabelece os requisitos necessários à obtenção de Registro ou Autorização para a implantação, ampliação ou repotenciação de centrais geradoras termelétricas, eólicas e de outras fontes alternativas de energia.

\subsubsection{Projetos de Lei do Senado $n^{\circ} 27$, de 1996}

Este Projeto cria o Programa de Incentivos a Energias Renováveis - PIER, que visa promover o desenvolvimento das energias termossolar, fotovoltaica e eólica, com os seguintes objetivos:

I. Estimular a produção das energias termossolar, fotovoltaica e eólica;

II. Incentivar a utilização das energias fotovoltaica e eólica em sistemas isolados de pequeno porte;

III. Incentivar a utilização da energia termossolar em aquecimento d'água para reduzir o consumo de eletricidade; 
IV. Incentivar o estabelecimento de cooperativas de produtores e usuários de energias solar e eólica.

A documentação referente a esta legislação se encontra na íntegra no Anexo $B$.

\subsection{Energia solar térmica}

A tecnologia de energia solar térmica é utilizada para a obtenção da quantidade de energia que um determinado corpo é capaz de absorver, sob forma de calor, a partir da radiação solar incidente sobre o mesmo.

Uma das aplicações que este tipo de tecnologia oferece é o aquecimento de água e para tal processo são utilizados equipamentos conhecidos como coletores solares. Os coletores solares são aquecedores de fluidos (líquidos ou gasosos) e não são utilizados para gerar eletricidade. Eles podem ser classificados em coletores concentradores e coletores planos, em função da existência ou não de dispositivos de concentração da radiação solar. O fluido aquecido é mantido em reservatórios termicamente isolados até o seu uso final (água aquecida para banho, refrigeração de ambientes, processos industriais de aquecimento, ar quente para secagem de grãos, gases para acionamento de turbinas).

O funcionamento dos sistemas de aquecimento solar é bastante simples: o coletor solar recebe a radiação solar que, sob forma de calor, é conduzida para a água no interior do coletor. A água é transportada para um reservatório térmico para ser utilizada e este transporte pode ser realizado de duas formas:

- Pela termofissão ou circulação natural;

- Pelo bombeamento ou circulação forçada.

$\mathrm{Na}$ termofissão, a água circula através do coletor devido à diferença de densidade entre a água fria contida no reservatório e a água quente do coletor. Estes sistemas em termofissão são de extrema confiabilidade e baixa manutenção. Sua aplicação restringe-se a instalações residenciais e pequenas instalações comerciais e industriais. 
Pequeno Porte

Pelo bombeamento, a circulação de água é feita por uma moto-bomba hidráulica acionada por um controlador eletrônico, que só aciona a bomba quando a água aquecida no coletor é suficiente.

Além dos coletores solares, para um sistema de aquecimento completo, são necessários um reservatório térmico, um sistema de circulação de água e, em alguns casos, um sistema auxiliar de aquecimento elétrico. Como grande parte do consumo de água quente ocorre em períodos de baixa ou nenhuma insolação, é necessário armazenar a água quente gerada no coletor solar para posterior utilização com a menor perda de calor possível - é esta a função do reservatório térmico. Em períodos prolongados de baixa insolação, caso a temperatura da água do reservatório térmico caia muito, a resistência do sistema de aquecimento auxiliar é acionada por um termostato, de forma a manter a água a uma temperatura especificada.

\subsubsection{Vantagens do aquecimento solar}

No Brasil, utiliza-se preferencialmente a energia elétrica para o aquecimento de água - mais de $67 \%$ de todo o consumo nacional de energia elétrica.[4] $\mathrm{O}$ uso da energia elétrica para este fim faz com que todo o sistema elétrico nacional tenha que ser superdimensionado para garantir o fornecimento no horário de pico - que corresponde ao período do dia mais crítico quanto à demanda de energia elétrica, usualmente situado entre 18 e 21 horas.

O chuveiro elétrico é basicamente um dos grandes fatores que elevam o pico de demanda, devido à sua alta potência e ao seu uso ser restrito a pequenos períodos - horários comuns para a maioria dos usuários. No Brasil, $97 \%$ das residências possuem chuveiro elétrico.

O incentivo à utilização de tecnologias alternativas para o aquecimento de água pode colaborar muito na redução do pico de consumo de energia ou pode deslocar, em parte, este pico de demanda de consumo. Além disso, pode proporcionar uma economia de energia na substituição da utilização da energia elétrica pela energia solar, causando um impacto positivo sobre o sistema de distribuição de energia. 
Pequeno Porte

O uso dos coletores solares para aquecimento de água em substituição de torneiras e chuveiros elétricos, pode representar uma economia de até $35 \%$ no consumo de energia elétrica de uma residência. Para a conservação de energia, o aproveitamento da energia solar para aquecimento de água tem se mostrado extremamente eficaz.

Para o consumidor, a economia a médio prazo pode ser significativa, já que o investimento inicial é recuperado num período de 18 a 24 meses e a vida útil média para tais sistemas é de, aproximadamente, vinte anos. Além de que, os sistemas de aquecimento solar exigem uma baixa manutenção, sendo a limpeza dos vidros coletores a manutenção mais importante.

\subsection{Arquitetura bioclimática - energia solar}

\section{passiva}

O estudo da arquitetura bioclimática é responsável por relacionar as construções ao clima e às características locais, visando aproveitar a ação do aquecimento e da iluminação provenientes da radiação solar incidente na arquitetura dos edifícios e outros tipos de construções. Procura-se aproveitar a energia solar, através de correntes convectivas naturais e de micro-climas criados por vegetações apropriadas, de maneira a reduzir o consumo de energia.

As técnicas passivas adotam soluções arquitetônicas e urbanísticas, adaptadas às condições específicas - clima e hábitos de consumo - de cada local, que visam explorar a energia solar, seja através de janelas colocadas em fachadas e orientadas de forma a evitar sombra e/ou de paredes que armazenam calor. Os edifícios que utilizam técnicas solares passivas através de fachadas e janelas apresentam uma diminuição considerável na procura de energia térmica, além de reduzir o consumo de energia para iluminação. Além disso, é importante destacar que a utilização de sistemas fotovoltaicos em edifícios comerciais parece particularmente vantajosa ao considerar que as atividades nestes edifícios concentram-se no mesmo período de disponibilidade da energia solar. Edifícios 
Pequeno Porte

comerciais apresentam também grandes áreas laterais e de teto, que podem ser aproveitadas para a instalação de painéis fotovoltaicos.

Tal técnica também pode ser aplicada no setor agrícola, pois a energia solar serve para o aquecimento de estufas e para a secagem de colheitas, por exemplo. Além disso, existe uma preocupação com o desenvolvimento de sistemas e equipamentos para aquecimento de água, circulação de ar e de água, iluminação e etc. necessários ao uso da edificação.

A geração de energia elétrica por conversão fotovoltaica é o principal foco deste trabalho, por isso o capítulo seguinte foi reservado para a apresentação desta tecnologia de conversão. 


\section{ENERGIA SOLAR FOTOVOLTAICA}

A energia emitida pela luz do Sol pode ser convertida diretamente em energia elétrica pelo efeito fotovoltaico, que constitui o princípio básico de funcionamento das células fotovoltaicas, unidades fundamentais do processo de conversão. O efeito fotovoltaico é definido com sendo a conversão direta da luz em eletricidade, ou seja, é o aparecimento de uma diferença de potencial elétrico nos extremos de uma estrutura de material semicondutor, produzida pela absorção da luz.

Inicialmente, o desenvolvimento da tecnologia de células fotovoltaicas estava voltado para o fornecimento de energia para sistemas de telecomunicações instalados em locais remotos e para o fornecimento de energia para satélites. Com a crise do petróleo, ocorrida entre 1973 e 1974, surgiu uma preocupação em estudar novas formas de produção de energia, o que causou um crescimento na utilização de células fotovoltaicas, ampliando a sua aplicação no meio terrestre para suprir o fornecimento de energia. Porém, os custos desta forma de conversão de energia eram elevados, o que impedia a difusão dos sistemas fotovoltaicos em larga escala. Para se ter uma idéia, o custo para a produção das primeiras células para programas espaciais era de US\$600/W. Em 1998, a produção de células fotovoltaicas atingiu a marca de $150 \mathrm{MWp}$, sendo o silício o material mais utilizado.

\subsection{Tecnologia de fabricação de células}

\section{fotovoltaicas}

Dentre os diversos semicondutores utilizados na tecnologia de fabricação de células fotovoltaicas destacam-se o Silício, nas formas monocristalina (mono-Si), policristalina (poli-Si) e amorfa (a-Si); o Telureto de Cádmio (CdTe) e os compostos relacionados aos disselenetos de Cobre e Índio ( $\mathrm{CulnSe}_{2}$ ou CIS) e de Cobre, Gálio e Índio (CulnGaSe ${ }_{2}$ ou CIGS). 
O silício é o segundo elemento mais abundante na superfície da Terra (mais de $25 \%$ da crosta terrestre é composta de silício). A célula de silício monocristalino é considerada a tecnologia fotovoltaica mais utilizada como conversor direto de energia solar em eletricidade, sendo este elemento extremamente robusto e confiável. Esta tecnologia é a única que faz uso de lâminas cristalinas (diâmetro de aproximadamente $10 \mathrm{~cm}$ ) relativamente espessas, o que representa uma maior limitação em termos de redução de custos de produção.

As outras tecnologias estão baseadas em películas delgadas (filmes finos com espessura da ordem de $1 \mu \mathrm{m}$ ) de material ativo semicondutor. $O$ desenvolvimento das tecnologias de filmes finos ocorre por eles apresentarem baixos custos de produção decorrentes das mínimas quantidades de material envolvido e por requererem uma menor quantidade de energia em sua produção.

Em termos de eficiência de conversão fotovoltaica, a tecnologia de silício cristalino é, dentre as tecnologias utilizadas em aplicações terrestres para gerar potência elétrica, a que apresenta a maior eficiência, em torno de $15 \%$ para painéis disponíveis no mercado. Já as tecnologias de filmes finos são menos eficientes, apresentando um rendimento entre $7 \%$ e 10\% para painéis comerciais, o que significa que é necessário quase o dobro da área em painéis solares de filmes finos para a obtenção da mesma energia fornecida pelos painéis de silício cristalino. Mesmo que os painéis solares de filmes finos apresentem atualmente um menor preço por Wp que os painéis de silício cristalino, deve-se considerar a área ocupada para uma determinada potência instalada na análise econômica ao optar por qual tecnologia fotovoltaica deve ser utilizada.

\subsubsection{Silício cristalino}

O silício cristalino é a tecnologia fotovoltaica mais tradicional e de maior escala de produção comercial, ainda que o custo de produção destes painéis solares de silício cristalino seja bastante elevado.

A fabricação da célula de silício inicia-se com a extração do cristal de dióxido de silício. Em seguida o material é desoxidado em grandes fornos, purificado e solidificado. Tal processo atinge um grau de pureza próximo de $98 \%$ ou $99 \%$, o que 
pode ser considerado eficiente sob o ponto de vista energético e de custo. Porém, para funcionar como célula fotovoltaica, é necessário um elevado grau de pureza, na faixa de $99,9999 \%$.

Para utilizar o silício na indústria eletrônica, além do alto grau de pureza, o material deve ter a estrutura monocristalina e uma baixa densidade de defeitos na rede cristalina. O crescimento do monocristal, nas células de silício monocristalino, é feito a partir de um banho de silício fundido de alta pureza em reatores sob atmosfera controlada a velocidades extremamente lentas. Complementando o crescimento do monocristal, se encontram as etapas de usinagem do tarugo; corte de lâminas por serras diamantadas; lapidação, ataque químico e polimento das lâminas; difusão e dopagem, deposição de máscara condutora de eletricidade gerada e, por último, a interconexão de células em série para a obtenção do painel fotovoltaico.

As lâminas cristalinas são cortadas com espessuras de $300 \mu \mathrm{m}$ a $400 \mu \mathrm{m}$, o que causa limitações em relação aos custos de produção. O consumo de energia neste processo é extremamente intenso, o que torna o tempo necessário para que 0 painel gere energia equivalente à utilizada em sua fabricação ("energy pay-back time") superior a três anos.

Dentre as células fotovoltaicas que utilizam o silício como material base, as monocristalinas são, em geral, as que apresentam maior eficiência, em torno de $15 \%$ para os melhores painéis disponíveis no mercado.

O silício policristalino apresenta menor eficiência de conversão e um custo de produção mais baixo, já que o processo de preparação das células é mais simples e a perfeição cristalina é menor que a do silício monocristalino. O material de partida é o mesmo que para o silício monocristalino, que é fundido e posteriormente solidificado direcionalmente, o que resulta em um cristal com grande quantidade de grãos, no contorno dos quais se concentram os defeitos que tornam este material menos eficiente que o silício monocristalino em termos de conversão fotovoltaica. As etapas complementares até a obtenção do painel fotovoltaico são semelhantes às realizadas no caso do silício monocristalino. $O$ processo de 
Pequeno Porte

fabricação de células policristalinas tem alcançado eficiência máxima em torno de 12,5\% em escalas industriais.[2]

\subsubsection{Silício amorfo hidrogenado}

A utilização de silício amorfo na fabricação de células fotovoltaicas apresenta grandes vantagens, tanto nas propriedades elétricas quanto no processo de fabricação.

Os processos de produção de silício amorfo ocorrem a temperaturas relativamente baixas $\left(<300^{\circ} \mathrm{C}\right)$, em processos a plasma, o que possibilita que estes filmes finos sejam depositados sobre substratos de baixo custo, como vidros, aço inox e alguns plásticos. Desta forma foram desenvolvidos painéis solares disponíveis no mercado que são flexíveis, mais leves, semitransparentes e com superfícies curvas. E, pelo fato de possuir aparência estética mais atraente, o silício amorfo tem encontrado aplicações arquitetônicas em substituição aos materiais de cobertura de telhados e fachadas.

Apesar de apresentar custo reduzido na produção, o uso de silício amorfo apresenta como desvantagens a baixa eficiência de conversão comparada às células mono e policristalinas de silício e o fato de que as células são afetadas por um processo de degradação logo nos primeiros meses de operação, o que reduz a eficiência ao longo da vida útil. Somente após um ano em operação é que ocorre a estabilidade na performance nos níveis da garantia do produto. Esta diminuição de rendimento, entretanto, já é assumida pelo fabricante e incluída na especificação do painel.

As vantagens de simplicidade e baixo custo do processo de fabricação, de existir a possibilidade de fabricação de células com grandes áreas - já que o custo do $\mathrm{m}^{2}$ de silício amorfo é inferior ao do silício cristalino - e do baixo consumo de energia na produção compensam as desvantagens descritas acima. Além de o tempo necessário para que o painel gere energia equivalente à utilizada em sua fabricação estar em torno de um ano, devido à energia utilizada na fabricação do substrato de vidro ou do aço inox. 
Pequeno Porte

Os melhores painéis de silício amorfo disponíveis no mercado apresentam eficiência em torno de $8 \%$ a $9 \%$.

\subsubsection{Telureto de cádmio e disseleneto de cobre e índio}

O telureto de cádmio e os compostos baseados no disseleneto de cobre e índio e no disseleneto de cobre, índio e gálio também são utilizados na forma de filmes finos e, assim como o silício amorfo, podem apresentar baixos custos para produção em grande escala e atingir eficiências relativamente altas.

Painéis solares de telureto de cádmio e de disseleneto de cobre e índio também apresentam uma ótima aparência estética, encontrando diversas aplicações arquitetônicas. Sendo assim deve-se levar em consideração aspectos como a pouca abundância dos elementos envolvidos e a toxidade caso estas tecnologias atinjam quantidades significativas de produção.

Os painéis de telureto de cádmio encontrados no mercado internacional apresentam eficiência entre $7 \%$ e $9 \%$ e os painéis de grande área $\left(1 \mathrm{~m}^{2}\right)$ de disseleneto de cobre e índio são encontrados com eficiência em torno de $9 \%$ e 10\%.

\subsection{Módulos solares fotovoltaicos}

Os módulos fotovoltaicos são os elementos que, conectados entre si, formam os arranjos fotovoltaicos. O módulo é a unidade básica de todo o sistema e é composto por células conectadas em arranjos produzindo tensão e corrente suficientes para a utilização da energia.

O agrupamento em módulos é indispensável pelo fato de uma célula fornecer pouca energia elétrica, em uma tensão em torno de $0,4 \mathrm{~V}$ no ponto de máxima potência e uma densidade de corrente da ordem de $30 \mathrm{~mA} / \mathrm{cm}^{2}$.

O número de células conectadas em um módulo e seu arranjo - série e/ou paralelo - depende da tensão de utilização e da corrente elétrica desejada. Os módulos também podem ser conectados em ligações série e/ou paralelo, dependendo da potência e da tensão desejadas. Quando a ligação é feita em série, 
as tensões são adicionadas e a corrente não é afetada. Já a conexão em paralelo causa a adição das correntes enquanto a tensão continua a mesma.

Para carregar baterias de $12 \mathrm{~V}$, os módulos fotovoltaicos devem produzir aproximadamente $16 \mathrm{~V}$ devido ao efeito da temperatura e às perdas que ocorrem nos cabos e diodos de bloqueio. Os módulos atualmente em operação têm entre 28 e 40 células de silício cristalino. O dispositivo de filme fino produz tensão mais alta que a forma cristalina e por isso os módulos podem ter menos de 28 células.

\subsubsection{Características elétricas dos módulos}

Os parâmetros elétricos que melhor caracterizam a funcionalidade dos módulos fotovoltaicos sob dadas condições de radiação, temperatura de operação e massa de ar são:

- Corrente de curto circuito (Isc);

- Tensão de circuito aberto (Voc);

- Potência máxima (Pm);

- Corrente de potência máxima (Imp) - utilizada como corrente nominal do mesmo;

- Tensão de potência máxima ( $(\mathrm{mp})$ - utilizada como tensão nominal do mesmo.

O ponto de potência máxima corresponde ao produto da tensão de potência máxima (Vmp) e da corrente de potência máxima (Imp). As condições padrão para a obtenção das curvas características dos módulos são definidas para radiação de 1 $\mathrm{kW} / \mathrm{m}^{2}$ (radiação recebida na superfície da Terra em dia claro, ao meio dia), temperatura de $25^{\circ} \mathrm{C}$ na célula (a eficiência da célula é reduzida com o aumento da temperatura) e massa de ar de 1,5 .

A figura 3.1 apresenta, em sobreposição, a curva característica $I x V$ e a curva típica de potência em função da tensão de uma célula de silício monocristalino. A curva característica $I x V$ é o resultado das medidas de corrente e tensão obtidas de acordo com as mudanças de condições de carga, onde para cada ponto desta curva o produto da corrente pela tensão representa a potência gerada para aquela condição de operação. A curva de potência em função da tensão mostra que para uma célula fotovoltaica e, consequentemente, para um módulo, existe 
Pequeno Porte

somente uma tensão (e corrente correspondente) para a qual a potência máxima pode ser obtida.

Para a curva característica $I x V$ a corrente de saída mantém-se praticamente constante dentro da amplitude de tensão de funcionamento e, portanto, o dispositivo pode ser considerado uma fonte de corrente constante neste âmbito.

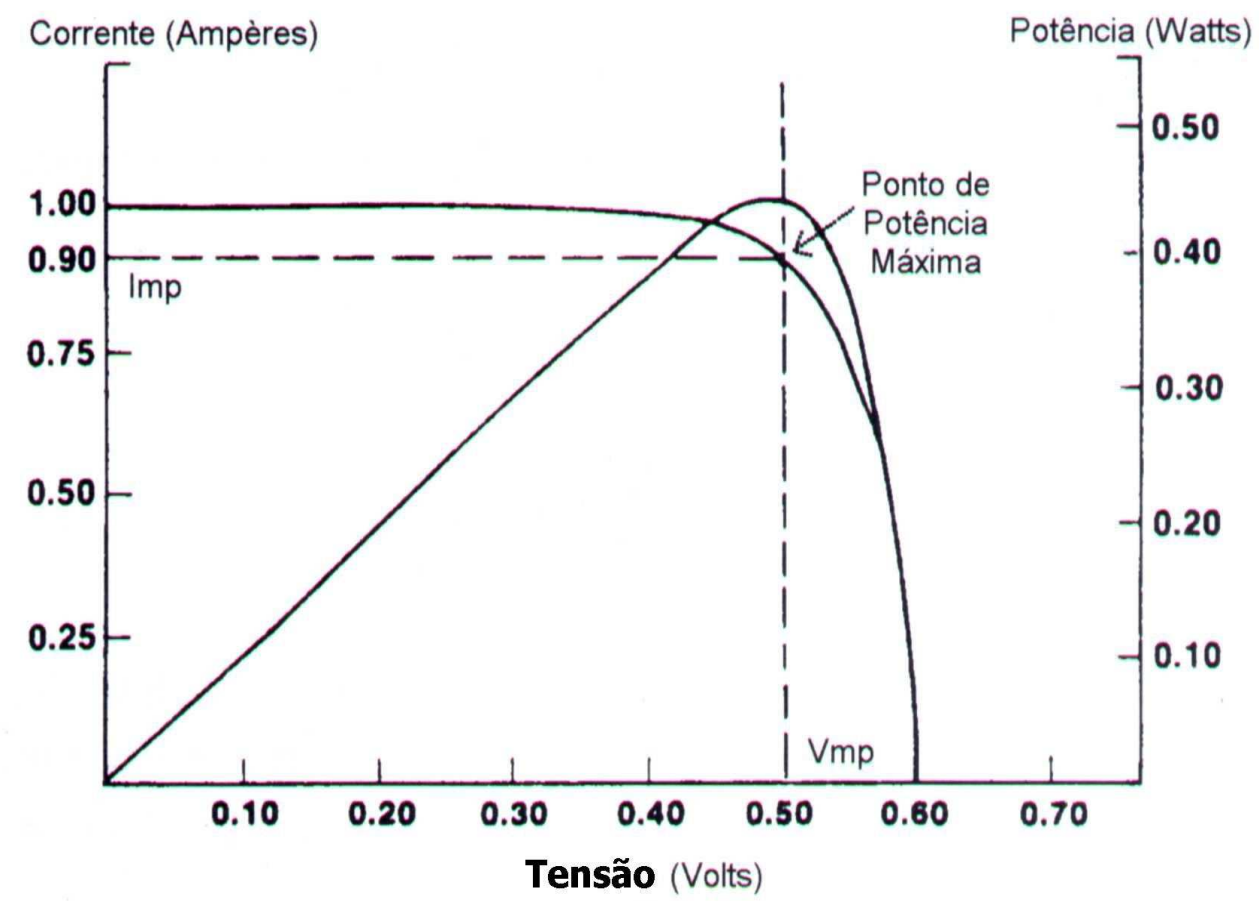

Figura 3.1 - Parâmetros de Potência Máxima de uma Célula de Silício Cristalino

(Fonte: CRESESB - “Energia Solar - Princípios e Aplicações”)

\subsubsection{Fatores que influenciam nas características elétricas dos módulos}

Os principais fatores que influenciam nas características elétricas de um módulo solar são a intensidade de radiação e a temperatura das células.

O resultado de uma mudança na intensidade de radiação é uma variação na corrente de saída para qualquer valor de tensão. A corrente gerada nos módulos aumenta linearmente com o aumento da intensidade de radiação, conforme ilustra a Figura 3.2. A característica $I x V$ de um módulo varia com as condições ambientais 
Pequeno Porte

(radiação, temperatura), o que quer dizer que haverá uma série de curvas $I x V$ que mostrarão as características de saída do módulo durante o dia numa época do ano.

Pelo fato de o Sol possuir movimento aparente no céu de acordo com a hora do dia e com o dia do ano, seria necessário o acompanhamento destes movimentos para receber maior intensidade de radiação. Porém, os módulos são geralmente instalados em posição fixa devido ao elevado custo dos equipamentos que permitem sua movimentação. É por isso que se deve determinar a melhor inclinação para cada região em função da latitude local e das características da demanda.

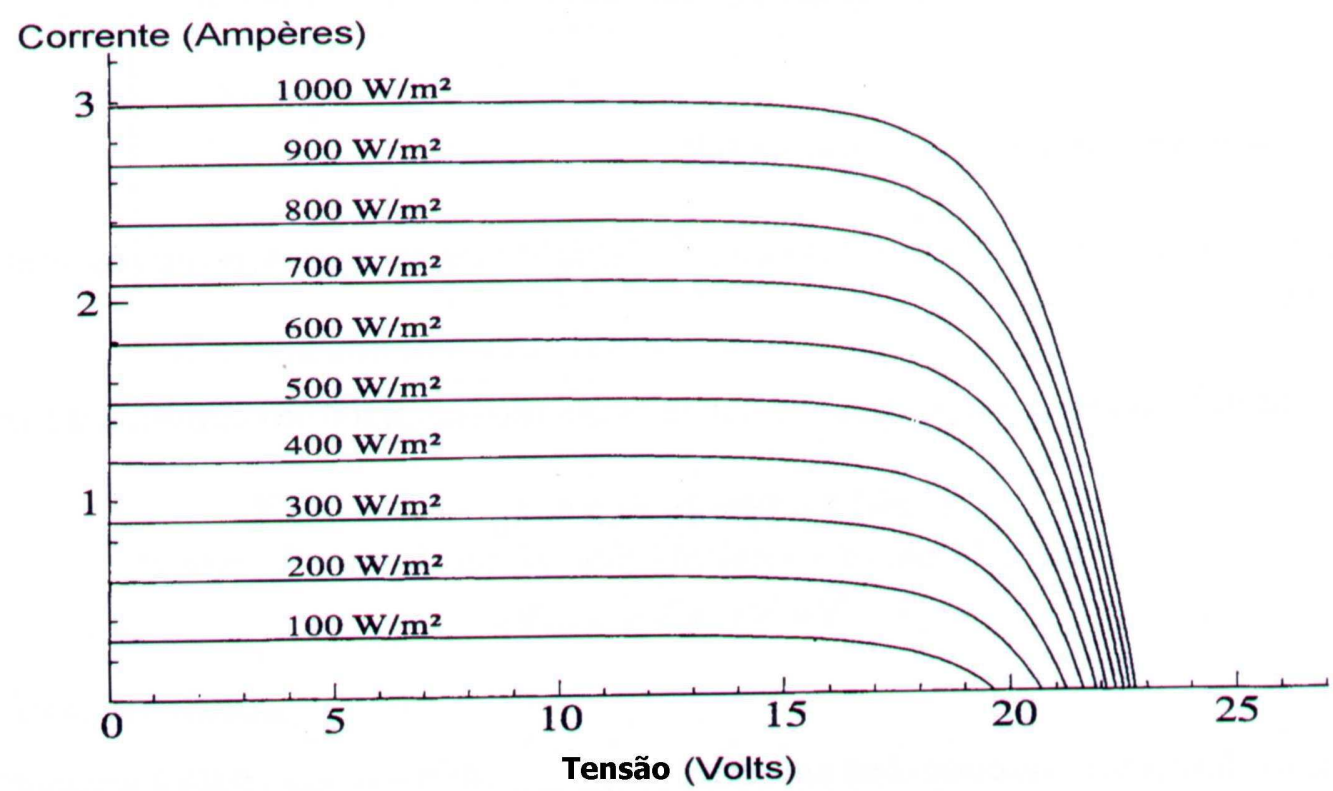

Figura 3.2 - Efeito causado pela variação de intensidade da luz na curva característica IxV para um módulo fotovoltaico

(Fonte: CRESESB - “Energia Solar - Princípios e Aplicações”)

A incidência de um nível de radiação e a variação da temperatura ambiente acarretam a variação de temperatura nas células que compõem os módulos fotovoltaicos. O aumento do nível de radiação aumenta a temperatura da célula e, consequentemente, diminui a eficiência do módulo. Isto se deve ao fato de que a tensão diminui significativamente com o aumento da temperatura enquanto a corrente sofre uma elevação quase desprezível, conforme mostra a figura 3.3. É por isso que para locais onde a temperatura ambiente é muito elevada são adequados 
Pequeno Porte

módulos que possuam maior quantidade de células em série a fim de que as mesmas tenham suficiente tensão de saída para carregar baterias.

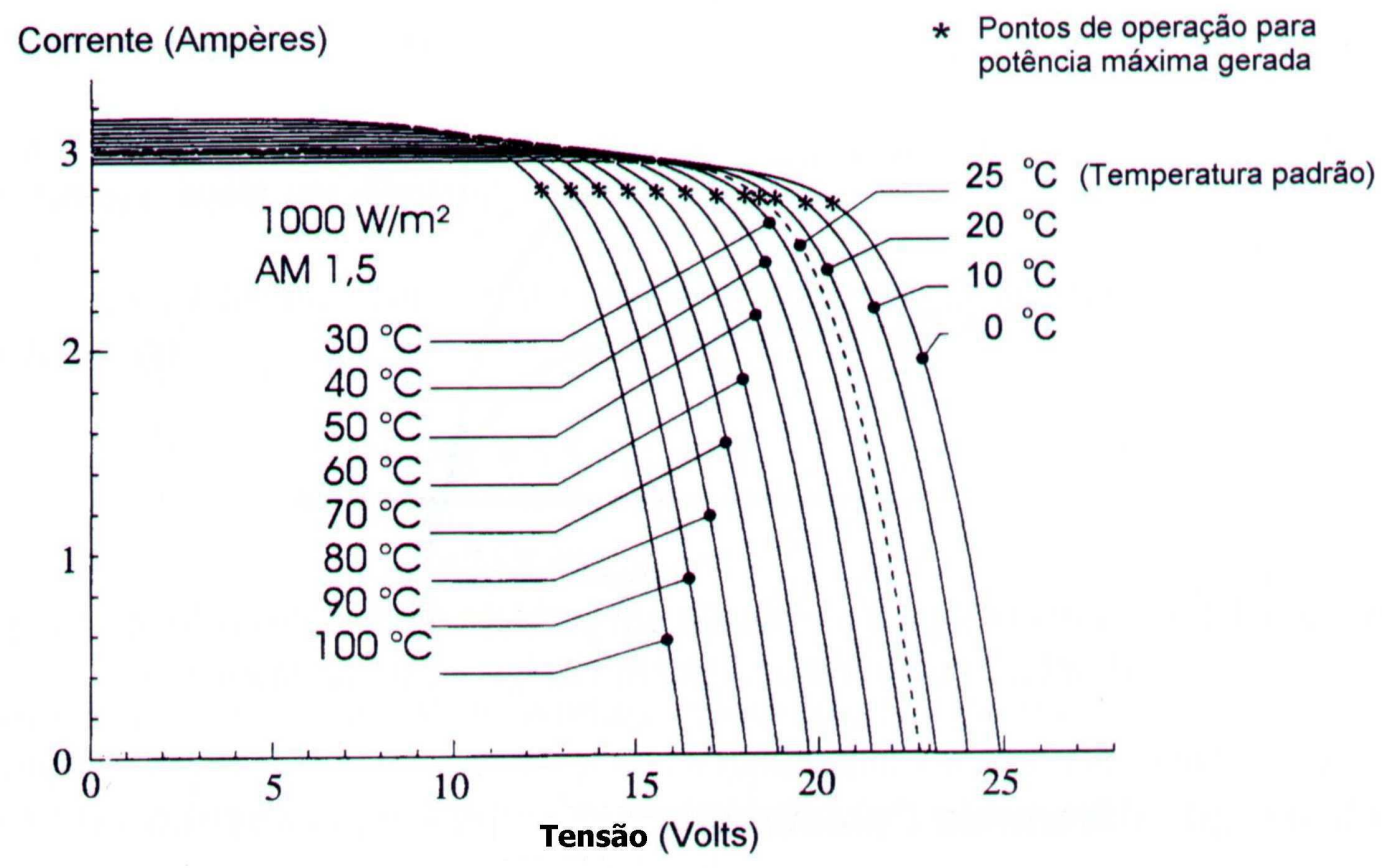

Figura 3.3 - Efeito causado pela temperatura da célula na curva característica IxV

(para $1000 \mathrm{~W} / \mathrm{m}^{2}$ ) em um módulo fotovoltaico de silício cristalino

(Fonte: CRESESB - “Energia Solar - Princípios e Aplicações”)

\subsection{Sistemas solares fotovoltaicos}

Os sistemas solares fotovoltaicos podem ser configurados de três formas distintas: podem funcionar de maneira isolada, ou autônoma; podem ser híbridos e também podem funcionar interligados à rede elétrica convencional. A utilização de cada uma destas opções dependerá da aplicação e da disponibilidade de recursos energéticos.

Os sistemas isolados diferem dos sistemas conectados à rede elétrica local fundamentalmente pela orientação dos painéis solares e pela existência ou não de um sistema acumulador de energia. Os sistemas autônomos não conectados à rede elétrica podem ou não apresentar fontes complementares de energia à geração fotovoltaica. Quando a configuração não se restringe à geração fotovoltaica, ou seja, 
caso existam outras formas de geração de energia como o gerador diesel ou as turbinas eólicas, têm-se os sistemas híbridos. Tanto os sistemas isolados quanto os sistemas híbridos necessitam de algum tipo de armazenamento, que podem ser as baterias, quando se deseja utilizar aparelhos elétricos nos períodos em que não há geração fotovoltaica.

Em instalações fotovoltaicas os painéis solares podem ser montados com orientação fixa ou podem estar acoplados a uma estrutura que permita o acompanhamento do deslocamento relativo do Sol ("tracking systems"). Nos sistemas autônomos de orientação fixa, quase sempre o arranjo dos painéis é orientado de forma a maximizar a captação solar nos meses de inverno, quando a oferta solar é menor e o consumo muitas vezes maior que nos meses de verão. Caso se deseje utilizar os sistemas de acompanhamento do deslocamento solar, deve-se proceder a uma análise que verifique se os custos envolvidos compensam a energia extra coletada, sem contar que neste caso novas peças móveis estão sendo introduzidas no sistema, acarretando maior manutenção.

\subsubsection{Sistemas isolados}

Basicamente, os sistemas isolados são utilizados para atender localidades remotas ou locais de difícil acesso, onde o fornecimento de energia elétrica através da rede pública convencional é inviável, tanto economicamente, quanto pela dificuldade de acesso. Os sistemas isolados podem estar configurados de diversas formas possíveis:

\subsubsection{Cargas em corrente contínua sem armazenamento}

Para este caso a energia elétrica é utilizada no momento da geração por equipamentos que operam em corrente contínua. Como exemplo, existem os sistemas de bombeamento de água através de bombas com motor de corrente contínua. 


\subsubsection{Cargas em corrente contínua com armazenamento}

Este é o caso em que se deseja alimentar equipamentos elétricos em corrente contínua, independente de haver ou não geração fotovoltaica simultânea. É necessário, então, que a energia elétrica seja armazenada em baterias. Exemplos deste caso são iluminação, rádio, televisão e sistemas de comunicação.

\subsubsection{Cargas em corrente alternada sem armazenamento}

Pode-se usar equipamentos que operem em corrente alternada da mesma forma como apresentado para cargas em corrente contínua desde que seja introduzido um inversor entre o arranjo fotovoltaico e as cargas a serem alimentadas. Um exemplo é a utilização de bombas com motores convencionais.

\subsubsection{Cargas em corrente alternada com armazenamento}

Um exemplo de aplicação desta configuração é o atendimento de residências isoladas que fazem uso de eletrodomésticos convencionais.

Em períodos de elevada irradiação solar ou em períodos de baixo consumo, armazena-se o excesso de energia gerada, normalmente em baterias, para que em períodos de baixa irradiação ou durante a noite essa energia seja utilizada. Mesmo que as baterias necessitem de manutenção e tenham a vida útil normalmente de quatro a seis vezes menor que a dos painéis fotovoltaicos, este sistema é economicamente competitivo se comparado aos sistemas convencionais, pois os custos envolvidos por estes sistemas fotovoltaicos são inferiores aos custos da extensão da rede elétrica pública para atender pequenas demandas.

\subsubsection{Sistemas híbridos}

Os sistemas híbridos são aqueles em que, estando desconectados da rede elétrica, existe mais de uma forma de geração de energia. Estes são sistemas mais complexos e que necessitam de algum tipo de controle capaz de integrar os vários geradores, de forma a otimizar a operação para o usuário. Existem várias 
Pequeno Porte

configurações possíveis e diversas estratégias de uso de cada fonte de energia: arranjos fotovoltaicos podem estar configurados juntamente com geradores a diesel ou turbinas eólicas, como na figura 3.4.

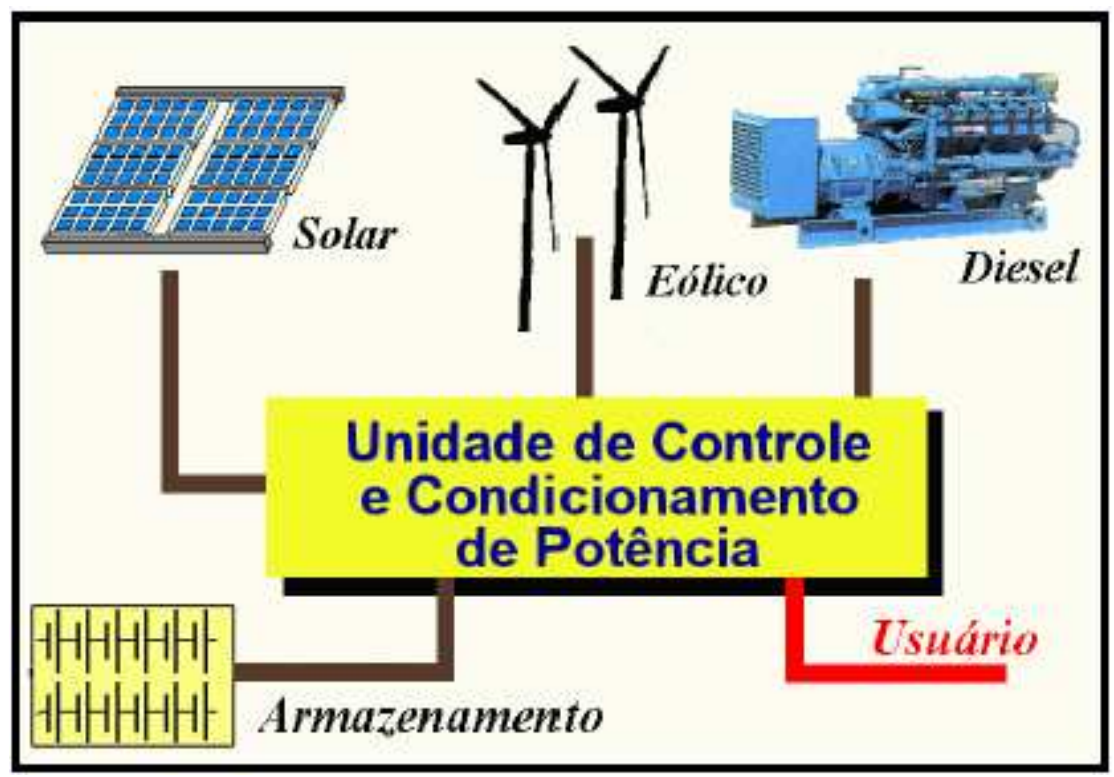

Figura 3.4 - Exemplo de Sistema Híbrido

(Fonte: CRESESB - "Energia Solar - Princípios e Aplicações”)

\subsubsection{Sistemas interligados à rede elétrica}

Os sistemas interligados à rede são aqueles em que a potência gerada pelo arranjo fotovoltaico é entregue à rede elétrica. Neste caso, a utilização de um inversor que satisfaça as exigências de qualidade e segurança é indispensável para que não ocorra a degradação da qualidade do sistema no qual se interliga o arranjo fotovoltaico. Neste tipo de sistema, o arranjo fotovoltaico representa uma fonte complementar ao sistema elétrico de grande porte ao qual está conectado e normalmente dispensa o uso de baterias, pois toda a potência gerada é entregue à rede instantaneamente.

A utilização de inversores para a conversão de corrente contínua em corrente alternada é importante, pois estes inversores controlam o fluxo de energia entre os painéis e a rede de energia. Eles possuem a função de minimizar o impacto da geração descentralizada sob o sistema de energia elétrica, impacto que inclui a 
minimização de distorções harmônicas nas formas de onda de tensão e corrente no ponto de acoplamento com a rede de energia.

Estes sistemas são encontrados integrados a prédios urbanos ou incorporados a fachadas e telhados, levando em consideração uma orientação solar favorável. Estas instalações começaram a ser usadas em diversos países da Europa, no Japão e nos Estados Unidos e apenas recentemente vêm sendo utilizadas no Brasil.

Pelo fato de a vida útil dos módulos ser de aproximadamente 30 anos, fazse necessário que a estrutura que os suporte seja construída de materiais duráveis e resistentes à corrosão. Mas deve-se prever a possibilidade de substituição individual dos módulos. A montagem de sistemas solares fotovoltaicos em telhados pode ser feita de três formas distintas:

- Os módulos podem ser montados em quadros de aço ou alumínio fixados em uma estrutura acabada do telhado, sendo este tipo de montagem o de menor custo.

- A montagem pode também ser em cobertura, onde os módulos são fixados diretamente nos caibros servindo de cobertura. Em vez de estarem sendo colocados diretamente nos telhados são colocados na sua estrutura. Este caso apresenta um custo excedente que é compensado pela economia de materiais de cobertura.

- Existem, também, as telhas solares que são fáceis de colocar mesmo sendo mais caras que os módulos. A diferença de preço é compensada, entretanto, pela inexistência da estrutura de montagem, que é desnecessária.

\subsubsection{Sistemas Residenciais}

Nos sistemas residenciais interligados à rede elétrica, o consumidor utiliza primeiro a energia gerada pelos painéis fotovoltaicos. Sempre que estes sistemas gerarem energia em excesso em relação ao consumo da residência, eles injetarão este excesso diretamente na rede elétrica pública. Quando o sistema fotovoltaico gerar menos energia do que a necessária para atender à demanda da residência (períodos de elevado consumo elétrico, ou de baixa incidência solar, ou à noite), a energia complementar necessária será obtida da rede. 
Tais sistemas dispensam, então, o uso de baterias, já que é a própria rede que armazena a energia. Além disto, não há a necessidade de superdimensionamento para atender aos períodos de picos de consumo da residência, já que a rede é que funciona como "back up".

Existem basicamente três tipos de conexão que variam quanto à forma de medição da energia. Elas devem atender as exigências de qualidade da energia impostas pela concessionária local, no que diz respeito aos limites de distorção harmônica, desvio de freqüência e fator de potência:

- Medição única do balanço de energia - opção que depende da concessionária remunerar a energia entregue pelo produtor fotovoltaico ao mesmo preço que ele compra dela. Um único medidor registra a entrada ou a saída de energia elétrica na residência e apresenta, ao final do período, a diferença entre energia consumida e energia entregue à rede.

- Medição dupla - os medidores operam cada um num sentido, registrando separadamente a compra e a venda de energia, o que pode fazer com que valores diferentes sejam atribuídos a cada uma das parcelas. A cada instante um dos medidores está em operação dependendo da diferença instantânea entre demanda e potência gerada pelo sistema fotovoltaico.

- Medições simultâneas - este arranjo é utilizado quando se deseja obter informações precisas sobre o consumo de energia e sobre a produção do sistema fotovoltaico. A conexão do sistema à rede é feita de forma independente, a fim de evitar interferências do circuito de consumo local com a produção e/ou tarifação da energia gerada. Por interesse do produtor fotovoltaico, a caixa de junção deve garantir que toda a energia gerada flua, para que, caso a rede não se encontre apta a receber esta energia, ela será comprada pela concessionária.

\subsubsection{Sistemas de grande porte}

São sistemas operados por empresas. Sua conexão com a rede é, em geral feita em média potência - 13,8 kV. A presença de um transformador neste tipo de sistema é essencial para elevar a tensão ao nível de distribuição. 


\subsection{Principais sistemas solares fotovoltaicos}

\section{instalados no Brasil}

Existem no Brasil diversos projetos envolvendo a utilização de energia solar para geração de energia elétrica. Estes projetos são, normalmente, financiados e instalados pelo governo e também por instituições privadas, além de existirem aqueles desenvolvidos por diversas Universidades Federais. O Grupo de Energia Solar da Universidade de São Paulo estima que devem existir 6MW instalados em sistemas fotovoltaicos no Brasil, distribuídos entre sistemas comunitários principalmente aqueles fornecidos pelo PRODEEM - e sistemas residenciais comercializados diretamente pelos distribuidores, quer em venda direta ou financiados com as linhas de crédito existentes.

O PRODEEM é um projeto de iniciativa do Departamento Nacional de Desenvolvimento Energético do Ministério das Minas e Energia (DNDE/MME) que tem como principal objetivo desenvolver projetos que atendam comunidades que não são servidas pelos sistemas convencionais de geração de energia. O Governo Federal financia o programa que, por licitação, adquire equipamentos e os entrega aos interessados. Para a coordenação e aplicação dos projetos, bem como o acompanhamento dos resultados, o programa possui parceria com diversas equipes regionais e com a maioria das Companhias Energéticas Brasileiras.

A maioria dos sistemas contratados pelo PRODEEM são sistemas fotovoltaicos que visam a eletrificação de escolas, de postos de saúde e de centros comunitários; a iluminação pública e o bombeamento d'água. O programa também visa a produção complementar de energia para todos os consumidores que são servidos pelos sistemas convencionais de energia, o que para as concessionárias apresenta uma grande vantagem, pois se pode reduzir o pico de demanda. São três os sistemas energéticos existentes e que atendem as comunidades isoladas:

- O individual, onde cada domicílio tem o seu módulo fotovoltaico, satisfazendo as necessidades energéticas da família; 
- O coletivo, onde a comunidade dispõe de uma estação de carga de baterias com sistema de troca, para as necessidades diárias;

- O comunitário, onde todos os setores sociais são eletrificados com fontes renováveis.

O Centro de Pesquisas de Energia Elétrica (CEPEL) também é um órgão que investe em projetos que utilizam energia solar para aquecimento solar, eletrificação rural e bombeamento de água. Em parceria com o Laboratório Americano de Energias Renováveis (NREL) e com as diversas concessionárias de energia elétrica do País ele implementa projetos de sistemas fotovoltaicos em diversas localidades do Brasil.

No nordeste, um dos projetos de destaque é o implementado pela Fundação Teotonio Vilela em parceria com a Companhia Energética do Estado de Alagoas (CEAL), que implantou estações fotovoltaicas de carga de baterias e o Sistema Solar Residencial ("Solar Home System"), que é um sistema autônomo instalado individualmente nas residências capacitado a prover o funcionamento contínuo com média de utilização diária de 3 a 4 horas.

Outras iniciativas de uso da energia solar fotovoltaica de destaque estão sendo coordenadas por diversas concessionárias de energia. A CEMIG, no estado de Minas Gerais, implantou um modelo no qual é cobrada uma tarifa para cobrir parte dos custos de atendimento aos domicílios isolados, sendo a outra parte dos investimentos coberta pela obrigatoriedade de alocação de parte de seus lucros em programas sociais. A COPEL, no Paraná, vem incorporando os sistemas renováveis solares como opção de seu programa de eletrificação rural e a CESP, em São Paulo, implantou um projeto piloto em que é cobrada uma tarifa pelo serviço prestado a sistemas residenciais solares.

Alguns dos principais projetos instalados no Brasil, segundo publicação do Centro de Referência para Energia Solar e Eólica Sérgio de Salvo Brito (CRESESB), estão descritos a seguir. 


\subsubsection{Eletrificação fotovoltaica na comunidade de Boa Sorte (Correguinho/MS)}

Este foi o primeiro Projeto-Pólo financiado pelo PRODEEM. O Sistema instalado, com potência total de 2,1 kWp, fornece energia para iluminação, radiocomunicação, bombeamento d'água e refrigeração de vacinas.

\subsubsection{Sistema de eletrificação comunitária no Ceará}

Este projeto de eletrificação fotovoltaica faz parte da primeira fase do acordo NREL/CEPEL/COELCE e é parte integrante do Programa LUZ DO SOL. O sistema foi instalado em várias localidades do interior do Ceará onde foram implantados sistemas de iluminação pública em cada localidade e instalados sistemas residenciais e escolares. O primeiro sistema foi instalado em dezembro de 1992 no município de Cardeiro.

Este projeto atende escolas de 14 vilas do interior do Ceará, onde foram instalados, também, 56 sistemas de iluminação pública, totalizando 30,74 kWp de potência solar instalada.

\subsubsection{Energização da comunidade Céu do Mapiá}

Esta comunidade situa-se no interior da Floresta Amazônica e foi atendida por um projeto financiado pelo Instituto de Promoção e Apoio ao Desenvolvimento (IPADE) e pela Agência Espanhola de Cooperação Internacional (AECI). O Projeto constitui a energização, com sistemas fotovoltaicos, de 6 locais públicos e 35 residências individuais, totalizando uma potência instalada de 1968 Wp.

\subsubsection{Sistema de eletrificação residencial em Pernambuco}

Este projeto faz parte da primeira fase do acordo NREL/CEPEL/CELPE dentro do Programa ALUMIAR - Energia Solar para o Homem do Campo, cujo sistema foi instalado em várias localidades do interior de Pernambuco. 
Pequeno Porte

O projeto atende a 10 municípios beneficiando um total de 341 residências, 3 escolas e uma igreja, onde o sistema apresenta um total de $36,57 \mathrm{kWp}$ de potência instalada.

\subsubsection{Sistema híbrido da Vila de Campinas}

\section{(Manacapuru/AM)}

O CEPEL implementou, em parceria com as concessionárias de energia elétrica locais, e com o suporte do NREL, este sistema localizado na Vila de Campinas a cerca de $100 \mathrm{~km}$ de Manaus entre os rios Negro e Solimões.

Este é um sistema híbrido fotovoltaico/diesel que utiliza um painel fotovoltaico de $50 \mathrm{kWp}$ e um banco de baterias de $192 \mathrm{kWh}$, estando associado a um sistema diesel já existente de 120 kVA.

Apesar de ter ocorrido uma redução no consumo de diesel, estendendo a vida útil dos geradores, e de a qualidade do serviço ter melhorado (suprimento de 24 horas/dia); considera-se que as tecnologias envolvidas não estão completamente desenvolvidas, resultando em diversos problemas técnicos. Além de as concessionárias terem encontrado dificuldades em relação à operação e à manutenção desta tecnologia.

\subsubsection{Sistemas solares conectados à rede elétrica pública}

Inicialmente, os sistemas solares fotovoltaicos estavam sendo planejados para geração de energia elétrica em localidades aonde a rede elétrica convencional não chegava. Com o aperfeiçoamento do processo de fabricação dos painéis fotovoltaicos, além da redução de custos, a aplicação desta fonte energética conectada à rede elétrica pública começa a ser estudada.

São diversas as vantagens que a geração fotovoltaica pode apresentar para as concessionárias:

- Em centros urbanos o uso de ar condicionado coincide com os máximos na geração fotovoltaica e isto pode aliviar os picos de consumo na rede, aumentando a vida útil do sistema de transmissão e distribuição. 
- Os curtos prazos de instalação de sistemas fotovoltaicos também são um atrativo.

- Em termos financeiros o que atrai são o fato de o capital investido começar a gerar energia quase que imediatamente e a inexistência de capacidade geradora ociosa devido à característica modular dos sistemas fotovoltaicos.

No Brasil, a primeira instalação fotovoltaica interligada à rede pública foi projetada e montada em um prédio do LABSOLAR da Universidade Federal de Santa Catarina (UFSC). O projeto partiu de uma instalação fotovoltaica de $2 \mathrm{kWp}$ composta de 68 painéis solares de silício amorfo, de um sistema inversor CC/CA, de medidores de radiação solar e temperatura e de um sistema de aquisição de dados. O monitoramento da energia gerada inclui potência CC, potência CA efetiva e energia total gerada.

\subsection{Considerações sobre a utilização de energia solar fotovoltaica}

No Brasil, a extensão territorial e os níveis elevados de irradiação solar durante todo o ano e em praticamente todo o território nacional, são algumas das principais justificativas de uma política de apoio a geração de energia a partir da tecnologia fotovoltaica.

As vantagens de se utilizar energia solar fotovoltaica para a geração de energia elétrica são:

- A simplicidade do método de conversão energética;

- A inexistência de peças mecânicas móveis;

- A caracterização modular dos sistemas (de mW até MW ou GW);

- Os curtos prazos de instalação;

- A baixa manutenção;

- A confiabilidade dos sistemas.

Além disso, os sistemas solares fotovoltaicos representam uma fonte silenciosa, não-poluente e renovável de energia elétrica que se adapta muito bem ao 
meio urbano, reduzindo substancialmente as perdas por transmissão já que a geração e o consumo estão próximos um do outro.

O aproveitamento da energia solar para o aquecimento de água, a fim de que se conserve energia, é extremamente eficaz, principalmente no Brasil que utiliza preferencialmente a energia elétrica para este fim. Devido aos custos competitivos, à tecnologia própria e à grande riqueza energética através do Sol, que é uma fonte inesgotável, o aquecimento solar tem grandes condições de se tornar uma opção brasileira para o aquecimento de água.

O uso de sistemas fotovoltaicos para bombeamento de água, além de se constituir em uma fonte limpa, sem ruído e sem peças móveis, possui uma característica única na relação natural entre a disponibilidade de energia solar e a demanda de água. Os sistemas de bombeamento de água baseados em fontes alternativas de energia se mostram competitivos em locais onde os insumos energéticos são abundantes (ventos e radiação solar) e as fontes tradicionais de eletricidade inexistem ou são economicamente inviáveis.

A integração de sistemas solares no momento da construção é uma alternativa mais econômica do que adaptar os imóveis já existentes, caso os painéis solares constituam a fachada, o custo de materiais de proteção é deduzido.

Mesmo assim, este tipo de instalação ainda é considerado caro. Vale ressaltar que o custo de sistemas fotovoltaicos não inclui somente o preço dos painéis solares, inclui também a ligação dos módulos, a estrutura de montagem, a cablagem, a regulação e o acondicionamento da eletricidade, além das baterias de armazenamento ou a ligação à rede pública.

Em termos absolutos, a produção anual de painéis solares fotovoltaicos ainda é insignificante, tanto no contexto energético mundial, quanto em relação aos níveis de produção necessários para que o seu potencial de redução de custos seja realizado. A energia solar fotovoltaica, atualmente, busca alternativas de mercado que possibilitem a expansão necessária para que ocorram investimentos necessários no aumento da capacidade de produção para reduzir seus custos. Os sistemas integrados a edificações urbanas e os sistemas interligados à rede elétrica pública são, no momento, um dos maiores mercados. 
Estudo de Sistemas Fotovoltaicos de

\section{ENERGIA EÓLICA}

A Energia Eólica é considerada uma das mais promissoras fontes renováveis de energia, principalmente devido ao grande avanço tecnológico ocorrido na Europa e nos Estados Unidos. Turbinas eólicas - instaladas isoladamente, ou em pequenos grupos de quatro ou cinco, ou em fazendas eólicas de mais de quinze aerogeradores - estão cada vez mais incorporadas à paisagem de países como a Alemanha, a Dinamarca, a Espanha e a Índia.

\subsection{O recurso eólico}

Os ventos são gerados pela não uniformidade do aquecimento da superfície terrestre, que é atribuída à orientação dos raios solares e aos movimentos da Terra. Daí, considera-se que a energia eólica (energia cinética dos ventos) seja proveniente da radiação solar absorvida pela Terra.

A formação dos ventos é determinada pelo deslocamento de massas de ar: 0 ar quente que se encontra nas baixas altitudes das regiões tropicais tende a subir e ser substituído por uma massa de ar frio que se desloca das regiões polares. As regiões tropicais são consideradas as mais aquecidas, pois recebem os raios solares quase que perpendicularmente.

Os parâmetros importantes que devem ser analisados para o aproveitamento da energia eólica são as variações temporais de velocidade e as mudanças de direção dos ventos. A medida de direção dos ventos auxilia na determinação da localização das turbinas em um parque eólico. Quanto à velocidade dos ventos é importante distinguir os vários tipos de variações temporais: variações anuais, sazonais, diárias e de curta duração:

- As variações anuais são importantes para o completo conhecimento do regime dos ventos. Com os dados obtidos ao longo dos anos, as características do regime local dos ventos se tornam mais confiáveis.

- As diferentes estações do ano resultam das variações sazonais na distribuição de radiação recebida na superfície da Terra, que originam as variações sazonais na 
intensidade e duração dos ventos. Em função da relação cúbica entre a potência disponível e a velocidade do vento na altura do eixo da turbina, mínimas variações de velocidade implicam em grandes variações de potência, o que faz necessária a utilização de médias sazonais.

- As variações diárias de velocidade dos ventos, caso das brisas marítima e terrestre, são importantes na determinação do local mais adequado de uma região para a instalação do sistema eólico. Existem variações da velocidade média ao longo do dia de um mês para outro, além de existirem locais onde os ventos são mais fortes durante o dia que durante a noite.

- As variações de curta duração estão associadas às pequenas flutuações e às rajadas de vento - caracterizadas por aumentos bruscos de curta duração da velocidade do vento. Essas variações não são consideradas, inicialmente, na análise do potencial eólico de uma região, porém devem ser constantemente observadas, pois as flutuações e a turbulência dos ventos podem afetar a integridade estrutural de um sistema eólico devido à fadiga que ocorre nas pás das turbinas.

Além da velocidade do vento existem outros parâmetros de igual importância que determinam a energia produzida por uma turbina eólica: a superfície varrida pelas pás e o rendimento do rotor e do gerador. A potência pode ser duplicada quando o comprimento das pás aumentar em $40 \%$.

Entretanto, alguns fatores referenciados aos parques eólicos causam um impacto ambiental: a emissão de ruídos e os problemas causados às aves são dois exemplos. Devido ao funcionamento mecânico e ao efeito aerodinâmico, as turbinas de grande porte apresentam um ruído de aproximadamente $50 \mathrm{~dB}$ junto a elas e de $35 \mathrm{~dB}$ a $450 \mathrm{~m}$ de distância. $O$ nível de ruído recomendável ao ser humano deve ser inferior a 40dB, o que corresponde a uma distância entre turbinas e habitações de $200 \mathrm{~m}$.

Alguns parques eólicos estão localizados em zonas de migração de aves, onde se observa que os pássaros morrem devido ao movimento de rotação das pás. Para evitar estes casos de mortalidade se faz necessária uma correta planificação na localização dos parques, evitando as rotas de migração. 


\subsection{Sistemas eólicos}

A energia cinética contida nas massas de ar (energia eólica) pode ser captada por turbinas e convertida em energia mecânica rotacional e, em seguida, convertida em eletricidade nos terminais de um gerador elétrico.

A relação entre a potência disponível do vento e a potência final entregue pelo sistema determina o rendimento global de um sistema eólico. O rendimento máximo ocorre à velocidade nominal e diminui para velocidades diferentes desta. Os rotores eólicos, ao extraírem a energia do vento, reduzem a sua velocidade: a velocidade do vento atrás do rotor (na esteira do rotor) é três vezes menor que a velocidade do vento frontal ao rotor (velocidade não perturbada), na condição de máxima extração de energia. Em condições ideais, cerca de 59\% da energia contida no fluxo de ar pode ser extraída por uma turbina eólica, porém, na prática, o rendimento aerodinâmico das pás reduz este valor, além de existirem perdas relacionadas aos componentes dos sistemas eólicos e do fato de o rotor funcionar em uma faixa limitada de velocidade do vento. O rendimento global de um sistema eólico simples pode, então, ser estimado em $20 \%$.

Os principais componentes de um sistema eólico que devem ser considerados na conversão eólica são: o rotor, a transmissão e a caixa multiplicadora, o gerador elétrico, o mecanismo de controle, a torre, o sistema de armazenamento e o transformador.

\subsubsection{0 rotor}

O rotor é responsável pela transformação da energia cinética do vento em energia mecânica de rotação. Ele é a característica principal de uma turbina eólica e sua configuração influencia diretamente no rendimento global de um sistema eólico. Os rotores são classificados basicamente em rotores de eixo horizontal e rotores de eixo vertical. 
Estudo de Sistemas Fotovoltaicos de

Pequeno Porte

\subsubsection{Rotores de eixo horizontal}

Os rotores de eixo horizontal são aqueles que possuem seu eixo paralelo à direção do vento. Eles são movidos por forças aerodinâmicas de sustentação, que atuam perpendicularmente ao escoamento e por forças de arrasto, que atuam na direção do escoamento. Estas forças são proporcionais ao quadrado da velocidade relativa do vento, sendo que os rotores que giram sob o efeito de forças de sustentação permitem maior liberação de potência que aqueles que giram sob efeito das forças de arrasto, para uma mesma velocidade de vento.

Os rotores de eixo horizontal (aerogeradores convencionais) são predominantemente movidos por forças de sustentação e estas forças dependem da geometria do corpo e do ângulo de ataque (entre a velocidade relativa do vento e o eixo do corpo). Eles devem possuir mecanismos capazes de permitir que o disco varrido pelas pás esteja sempre em posição perpendicular ao vento.

Os principais rotores de eixo horizontal utilizados são os do tipo hélice compostos de três ou duas pás. A potência gerada por um rotor de três pás é um pouco maior que a gerada pelo de duas pás, sendo a configuração de três pás a mais utilizada.

A potência gerada por turbinas de eixo horizontal é proporcional à área abrangida pelo rotor em movimento, sendo o limite máximo típico de produção de uma turbina de médio porte de $400 \mathrm{~W} / \mathrm{m}^{2}$. Comercialmente, o tamanho dos rotores varia de $1 \mathrm{~m}$ de diâmetro, com potência nominal de 50W, a $66 \mathrm{~m}$ de diâmetro, com potência nominal de 1,5MW.

\subsubsection{Rotores de eixo vertical}

As turbinas de eixo vertical possuem o eixo do rotor perpendicular à velocidade do vento. Nestas turbinas o ângulo de ataque em qualquer ponto da pá varia com o tempo, acarretando potências e cargas instáveis, limitando seu rendimento e causando vibrações em sua estrutura. Apesar disto, estas turbinas não necessitam de mecanismo que acompanhem as variações de direção do vento, 
Pequeno Porte

sendo utilizadas nos aeromotores por simplificar os mecanismos de transmissão de potência.

Os principais rotores de orientação vertical são o Savonius, que é indicado para aeromotores para pequenos sistemas de bombeamento d'água, já que é de menor rendimento; e o Darrieus. Estes rotores de eixo vertical são pouco produzidos, pois sua utilização é considerada um desperdício de recursos.

\subsubsection{Transmissão e caixa multiplicadora}

A transmissão, que engloba a caixa multiplicadora, é responsável por transmitir a energia mecânica entregue pelo eixo do rotor à carga. É composta por eixos, mancais, engrenagens de transmissão e acoplamentos.

A caixa de transmissão mecânica é geralmente colocada entre o rotor e o gerador de forma a adaptar a baixa velocidade do rotor, que se encontra na faixa de 20 a 150 rpm, à velocidade de rotação mais elevada dos geradores, normalmente síncronos, que se encontra entre 1200 e 1800 rpm.

Porém, já foram desenvolvidos aerogeradores que não utilizam a caixa multiplicadora. Em vez de utilizar a caixa de engrenagens com alta relação de transmissão, necessária para alcançar a elevada rotação dos geradores, são utilizados geradores multi-pólos de baixa velocidade e grandes dimensões.

\subsubsection{0 gerador elétrico}

O gerador é responsável pela conversão da energia mecânica de rotação em energia elétrica. Existem diversos fatores que dificultam a integração entre os geradores e os sistemas de conversão eólica:

- As variações na velocidade do vento que produzem uma extensa faixa de rotações por minuto para a geração;

- As variações de torque de entrada, já que as variações na velocidade do vento induzem variações de potência disponível no eixo;

- A exigência de freqüência e tensão constantes na energia final produzida. 
Costuma-se utilizar o gerador de simples indução, porém o tipo alternativo síncrono possui a vantagem de ser excitado pela rede, apesar de demandar um controle preciso da velocidade do rotor para o sincronismo de partida.

Os geradores multi-pólos, que eliminam a necessidade da caixa de engrenagens, podem ter até duas rotações de trabalho, tendo dois estágios de funcionamento. Um estágio onde a eficiência máxima ocorre a baixas velocidades de vento (primeiro nível de rotação constante do motor) e outro estágio de eficiência máxima a velocidades de vento mais altas (segundo nível de rotação constante do rotor). Este tipo de gerador vem sendo utilizado em turbinas mais modernas.

\subsubsection{Mecanismo de controle}

O mecanismo de controle é responsável pela orientação do rotor, pelo controle de velocidade e pelo controle da carga.

O controle de potência é necessário devido à instabilidade do vento. A turbina não deve ser exposta a potências muito superiores à sua potência nominal porque existe o risco de danos para a caixa de engrenagens e para o gerador. Existem, portanto, dois diferentes princípios de controle aerodinâmico: o controle de passo de pá e o controle de estol.

\subsubsection{Controle de passo de pá}

O passo de pá é o ângulo formado entre o perfil transversal da pá e o plano definido pelo rotor em rotação.

Em sistemas de controle de passo, quando a potência nominal do gerador é ultrapassada, devido ao aumento das velocidades do vento, as pás mudam seu ângulo de passo para reduzir o ângulo de ataque do fluxo de ar. Tal redução diminui as forças aerodinâmicas atuantes e, por conseqüência, a extração de potência do vento pela turbina. Cerca de $50 \%$ dos aerogeradores instalados na Alemanha são do tipo controle de passo. 
Estudo de Sistemas Fotovoltaicos de

Pequeno Porte

\subsubsection{Controle de estol}

O controle de estol é um sistema passivo que reage à velocidade do vento. As pás do rotor são fixas em seu ângulo de passo e não podem girar em torno de seu eixo longitudinal. O ângulo de passo é escolhido de forma que, para velocidades de vento superiores à velocidade nominal, o fluxo em torno do perfil da pá do rotor descola da superfície da pá (estol), o que reduz as forças de sustentação e aumenta as forças de arrasto, atuando contra um aumento da potência do rotor. Para evitar que o estol ocorra em todas as posições radiais das pás simultaneamente, o que reduziria a potência do rotor, as pás possuem uma torção longitudinal que as levam a um suave desenvolvimento do estol.

As turbinas com controle de estol são mais simples que as de controle de passo porque não necessitam de um sistema de mudança de passo. A maioria dos fabricantes utiliza os sistemas de controle de estol que necessitam de uma velocidade constante do rotor, geralmente fornecida pelo gerador de indução diretamente acoplado à rede.

\subsubsection{Sistema de armazenamento}

Devido à mudança de comportamento dos ventos ao longo do tempo, a utilização de sistemas de armazenamento de energia, que garantem o fornecimento adequado à demanda, pode ser necessária.

O armazenamento de energia é necessário, para adaptar o perfil aleatório de produção energética ao perfil de consumo, quando a energia eólica é utilizada como fonte primária de energia. $\mathrm{O}$ excesso de energia durante os períodos de ventos de alta velocidade é armazenado para ser utilizado quando o consumo não puder ser atendido pela insuficiência de ventos.

Quando a energia eólica á utilizada para complementar a produção de energia convencional, não é necessário o armazenamento de energia, já que a energia gerada é injetada diretamente na rede elétrica.

As formas mais comuns de armazenamento de energia eólica são através de baterias ou como energia gravitacional. 


\subsection{Aplicações dos sistemas eólicos}

Existem três distintas formas de utilização dos sistemas eólicos, que são definidas em função da aplicação a que se dispõem, e se classificam em sistemas isolados de pequena dimensão, sistemas híbridos de média dimensão e sistemas interligados a rede de grande dimensão.

Os sistemas obedecem a uma configuração básica, necessitando de uma unidade de controle de potência e, em alguns casos, de uma unidade de armazenamento. O que leva à necessidade de um controle de potência é a instabilidade dos ventos, já que as turbinas não podem ser expostas a potências muito superiores à potência nominal para não causar danos à caixa de engrenagens e ao gerador.

\subsubsection{Sistemas Isolados de pequena dimensão}

Os sistemas isolados delimitam a potência entre $25 \mathrm{~W}$ e $10 \mathrm{~kW}$ e são sistemas que, em geral, utilizam alguma forma de armazenamento de energia. Este armazenamento pode ser feito em baterias para utilização de aparelhos elétricos ou na forma gravitacional para bombeamento de água.

Em sistemas que armazenam energia em baterias necessita-se de um controlador de carga para evitar danos à bateria por sobrecarga ou descarga profunda. Este controlador é utilizado em sistemas de pequeno porte onde os aparelhos são de baixa tensão e corrente contínua. Caso se deseje alimentar aparelhos que operam em corrente alternada deve-se utilizar um inversor também.

Os sistemas isolados possuem sua aplicação limitada a pequenos sistemas em regiões remotas, pois existem complicações dos sistemas de armazenamento que tornam os sistemas bastante dispendiosos, já que as variações instantâneas e diárias e de disponibilidade nos períodos do ano devem ser compensadas. Estes sistemas são utilizados quando o benefício e o conforto compensam o alto custo por watt obtido.

Os sistemas eólicos de bombeamento d’água, disponíveis no mercado na faixa de $1 \mathrm{~kW}$ a $10 \mathrm{~kW}$ são os sistemas de menor custo entre as aplicações de 
Estudo de Sistemas Fotovoltaicos de

Pequeno Porte

energia eólica. Tais custos se justificam pela ausência de baterias e conversores estáticos, pela mínima manutenção, pelo uso de motobombas convencionais e pela possibilidade de separação na alocação da bomba e do rotor eólico de até $1 \mathrm{~km}$.

\subsubsection{Sitemas híbridos de média dimensão}

Os sistemas híbridos são sistemas eólicos combinados com sistemas fotovoltaicos ou com geradores a diesel e que dispensam equipamentos de armazenamento de energia, pois o sistema auxiliar supre a baixa oferta de energia nos períodos de baixa incidência de vento. Sua potência varia entre $10 \mathrm{~kW}$ e $200 \mathrm{~kW}$.

Nestes sistemas, os geradores eólicos representam um fator de economia de combustível com custos atraentes para localidades que não dispõem da rede de distribuição interligada, pois podem funcionar como centrais geradoras conectadas a uma rede isolada que suprem a demanda de energia elétrica destas comunidades não atendidas pelo sistema interligado.

A utilização de várias formas de geração de energia, entretanto, aumenta a complexidade do sistema e exige a otimização do uso de cada uma das fontes, sendo necessário um controle de todas as fontes para que haja máxima eficiência na entrega da energia para o usuário final. Por causa da grande complexidade de arranjos e da multiplicidade de opções, a otimização se torna particular para cada caso de estudo, justificando o elevado custo deste tipo de sistema.

No Brasil, o primeiro aerogerador de grande porte foi instalado em Fernando de Noronha em 1992. Trata-se de uma turbina de $75 \mathrm{~kW}$, com rotor de três pás de 17 metros de diâmetro que foi integrada ao sistema de fornecimento de energia, formando um sistema híbrido com gerador diesel. Ocorreu, neste caso, uma economia em torno de $10 \%$ no consumo de diesel, além da redução de emissão de poluentes. 


\subsubsection{Sistemas de grande dimensão interligados à rede elétrica}

Sistemas interligados à rede de distribuição dispensam os sistemas de armazenamento de energia já que toda a geração é entregue diretamente à rede. Eles representam uma fonte complementar ao sistema elétrico de grande porte ao qual estão interligados, podendo representar cerca de $15 \%$ do fornecimento total de energia.

As potências unitárias típicas das turbinas de ligação à rede estão entre $100 \mathrm{~kW}$ e $1500 \mathrm{~kW}$. Estas turbinas normalmente são instaladas em grande número constituindo parques ou fazendas eólicas que totalizam uma potência instalada entre $1 \mathrm{MW}$ e 100MW.

O maior parque em operação situa-se em Holtriem na Alemanha, com potência instalada de 52,2MW - 35 máquinas de 1500kW. No Brasil, destacam-se os parques do Camelinho $(1 \mathrm{MW})$ e do Gouvêia (1MW) em Minas Gerais, do Mucuripe $(1,2 \mathrm{MW})$, do Taíba $(5 \mathrm{MW})$ e da Prainha (10MW) no Ceará.

Em janeiro de 1999 foi instalado o primeiro parque eólico da região Sul parque eólico de Palmas no Paraná - com 2,5MW que promoveu a elevação da potência instalada no país, ultrapassando os 20MW.

A penetração de energia eólica admissível em grandes redes está em torno de $15 \%$ a $20 \%$, tornando necessárias precauções em relação à qualidade da tensão e da freqüência e à estabilidade da rede. Para que a energia gerada seja lançada diretamente na rede, todo arranjo deve ser conectado a inversores que devem satisfazer exigências de qualidade e segurança para não afetar a rede.

Para a implantação de parques geradores eólicos se faz necessário um estudo de viabilidade. Preliminarmente, se faz um estudo de identificação dos locais mais propícios à instalação de parques geradores eólicos e instalam-se estações de medição eólica. Os dados obtidos destas estações de medição permitem o estudo de viabilidade de implantação dos parques (custo da energia gerada, investimentos totais com infra-estrutura e interligação ao sistema elétrico, estudos iniciais de impacto ambiental, dentre outros). Pode-se afirmar que a implantação de um parque 
eólico requer uma avaliação mais apurada do regime dos ventos, que é realizada mediante a instalação de estações de medição nos locais onde se pretende construir tais parques.

O levantamento do potencial eólico da região é uma das maiores preocupações no projeto de fazendas eólicas. Devem ser considerados dados de um período mínimo de um ano sobre a velocidade do vento no local, além de modelos matemáticos baseados em dados fornecidos por estações de medição.

\subsection{Panorama da energia eólica}

Em decorrência da crise do petróleo ocorrida na década de 1970, surgiu um grande interesse dos países europeus e dos Estados Unidos em desenvolver equipamentos que ajudassem a diminuir a dependência do petróleo e do carvão. Iniciava-se, então, a utilização da energia eólica para geração de eletricidade em escala comercial, e a evolução dos equipamentos para este tipo de geração ocorria rapidamente.

Segundo dados do Centro Brasileiro de Energia Eólica - CBEE, atualmente existem mais de 30.000 turbinas eólicas de grande porte em operação no mundo, com capacidade instalada da ordem de $13.500 \mathrm{MW}$.

Na Dinamarca, a contribuição da energia eólica é de $12 \%$ da energia elétrica total produzida; no norte da Alemanha a contribuição eólica ultrapassou 16\%; e a União Européia tem como meta gerar $10 \%$ de toda eletricidade a partir do vento até 2030. [9]

No Brasil, o potencial energético eólico estimado é de cerca de 10GW em potência aproveitável. O estado do Ceará foi um dos primeiros locais a realizar um programa de levantamento do potencial eólico, mostrando que foram identificadas áreas de grande potencial eólico na costa do nordeste.

A capacidade instalada no Brasil é de 20,3MW com turbinas eólicas de médio e grande porte conectadas à rede elétrica. Os estados do Ceará, de Pernambuco, de Minas Gerais e do Paraná são os que mais possuem instalações 
de grande porte. Existem, também turbinas de pequeno porte funcionando em locais isolados da rede elétrica convencional. [9]

No Fórum Permanente de Energias Renováveis, realizado em Brasília, estabeleceu-se a meta de instalar 1.000MW de energia eólica no País até o ano de 2005. Estima-se que serão 1.600 turbinas eólicas, cada uma delas com capacidade máxima de 600kW. [9]

\subsection{Potencial eólico brasileiro}

Uma avaliação precisa do potencial dos ventos em uma região é o principal passo para o aproveitamento do recurso eólico como fonte de energia.

No Brasil, os primeiros anemógrafos computadorizados e sensores especiais para energia eólica foram instalados no Ceará e em Fernando de Noronha, em Pernambuco, apenas no início dos anos 90, obtendo bons resultados que favoreceram a determinação precisa do potencial eólico destas regiões e a instalação de turbinas eólicas. Atualmente, existem mais de cem anemógrafos computadorizados espalhados por vários estados brasileiros.

O nordeste é uma região caracterizada pelos ventos comerciais, segundo a análise dos dados dos ventos de várias localidades desta região, estes ventos comerciais se caracterizam por altas velocidades médias, pouca variação nas direções dos ventos e pouca turbulência ao longo do ano. Em 1998, o CBEE com o apoio da Agência Nacional de Energia Elétrica - ANEEL e do Ministério de Ciência e Tecnologia - MCT lançou a primeira versão do Atlas Élico do Nordeste do Brasil ("Wind Atlas for the Northest of Brazil" - WANEB), que tem como objetivos o desenvolvimento de modelos atmosféricos, a análise de dados de ventos e a elaboração de mapas eólicos confiáveis para a região.

A COPEL, em 1999, publicou o mapa do potencial eólico do estado do Paraná, utilizando dados de vento de cerca de vinte estações anemométricas para simulações em modelo atmosférico de microescala. Neste mesmo ano, o CBEE iniciou a elaboração da segunda versão do Atlas Eólico do Nordeste (WANEB2) e do Atlas Eólico Nacional em um projeto envolvendo a coleta e o processamento de 
Pequeno Porte

dados de vento de boa qualidade medidos em estações terrenas e na atmosfera (sondas e satélites), a simulação de climatologia com o modelo atmosférico de mesoescala MM5 em resolução de $30 \mathrm{~km}$ e a elaboração do Atlas Eólico a partir da combinação dos mapas de vento com informações de topografia, uso do solo e influências locais. O CBEE estima que o potencial eólico existente no Nordeste é de 6.000MW. [9]

Em Santa Catarina, os primeiros estudos desenvolvidos pelas Centrais Elétricas de Santa Catarina - CELESC indicam a presença de alguns locais favoráveis na região de Lages (planalto central), próximo a Laguna (litoral sul) e próximo a Palmas (meio-oeste próximo ao Paraná), onde foram encontradas médias locais de velocidade do vento próximas a $9 \mathrm{~m} / \mathrm{s}$.

\subsection{Projetos de Energia Eólica no Brasil}

Vários foram os estados que iniciaram medições de vento, principalmente Minas Gerais, Ceará, Bahia, Paraná e Santa Catarina, além de se encontrarem em diferentes estágios de negociação para implantação de projetos eólicos conectados à rede. Em documentos do MCT afirma-se que os projetos mais promissores estão localizados no Ceará, onde estão implantados 16,2MW e no Paraná, onde se encontram 2,5MW.

No estado do Ceará existe a previsão de implantação de dois projetos (Paracurú e Camocim) de 30MW, originários de um acordo entre o governo estadual e a Companhia Elétrica do Ceará (COELCE) com fundos da Organização Japonesa OECF. Um outro projeto resultante do acordo assinado entre a Thyssen-Krupp e o governo do Ceará é a criação de uma fazenda eólica de 100MW.

Conforme informe do MCT, existem estudos de um parque eólico de 50MW em Salinópolis, no Pará, pela empresa Wobben; de um parque de 100MW em Jericoacoara (CE), pela COELCE; um parque de 50MW em Cabo Frio (RJ) pelas empresas Proven/Vestas (Eletrobrás) e a expansão do Parque de Palmas, no Paraná, incorporando mais $85 \mathrm{MW}$ à região. 
Alguns dos principais Sistemas Eólicos, segundo publicação do CRESESB [7], estão descritos abaixo:

\subsubsection{Fazenda eólica em Minas Gerais}

Em medições e avaliações do regime de ventos no morro do Camelinho, ficou demonstrado de tal região se apresentava como promissora para o aproveitamento energético de vento, o que levou a CEMIG a escolher a região para desenvolver novos estudos para implementação de um sistema de grande porte.

Em 1992, esse projeto foi enquadrado no Programa Eldorado do MCT e do Governo Alemão. A usina foi instalada em 1994 e opera com capacidade de 1MW (quatro turbinas eólicas de $250 \mathrm{~kW}$ cada). Para a velocidade de vento média do local, estimada entre $6 \mathrm{~m} / \mathrm{s}$ e $7 \mathrm{~m} / \mathrm{s}$ (a 30 metros de altura) prevê-se uma produção média anual de energia elétrica entre 1500 MWh e 1800 MWh.

\subsubsection{Fazenda eólica de Mucuripe (Fortaleza/CE)}

Em novembro de 1996, a COELCE inaugurou o parque anemoelétrico de Mucuripe, que está instalado na praia Mansa do Porto de Mucuripe e tem potência nominal de 1200 kW. Esse sistema é capaz de produzir cerca de 3,8 milhões de kWh por ano - energia elétrica suficiente para abastecer uma cidade de 15.000 habitantes com 3.000 residências de médio porte.

O objetivo geral deste projeto é demonstrar a viabilidade técnica e econômica da produção de eletricidade em escala comercial, através da energia eólica, no litoral do Ceará, além de:

- Avaliar a confiabilidade e o desempenho operacional de sistemas de conversão de energia eólica nas agressivas condições climáticas da costa cearense.

- Determinar as condições de competitividade econômica e os custos envolvidos no projeto.

- Capacitar recursos humanos locais no dimensionamento, na instalação, na operação e na manutenção de parques eólicos. 
- Criar condições favoráveis para viabilizar o processo de transferência de tecnologia visando a produção local de componentes e equipamentos importados.

- Incentivar o setor privado a investir na geração de eletricidade através de fontes energéticas locais.

\subsubsection{Sistemas híbridos}

Em relação aos sistemas híbridos, existe um único sistema eólico/diesel de grande porte instalado no Brasil que é o sistema da ilha de Fernando de Noronha. A geração diesel da ilha tem uma capacidade instalada de aproximadamente $2 \mathrm{MW}$ com dois grupos geradores de 350kVA e três de 450kVA. Duas turbinas eólicas, $75 \mathrm{~kW}$ e $225 \mathrm{~kW}$ de potência nominal, estão conectadas diretamente à rede elétrica formando um sistema integrado. A energia gerada pelas turbinas eólicas contribui com cerca de $25 \%$ da demanda da llha.

Vários projetos de sistemas híbridos eólico/solar/diesel de pequeno porte foram desenvolvidos para comunidades isoladas e outras aplicações. Dentre eles:

\subsubsection{Sistema híbrido para testes do CBEE}

Sistema instalado em Recife - Pernambuco - que possui uma turbina eólica de 1,5 kW de potência nominal, com diâmetro do rotor de 3 metros (três pás) e uma torre de 18 metros de altura; e módulos fotovoltaicos que somam $360 \mathrm{Wp}$ com um banco de baterias de $180 \mathrm{Ah}, 120 \mathrm{~V}_{\mathrm{DC}}$ de capacidade. Este sistema é aplicado em pesquisa de demonstrações.

\subsubsection{Sistema híbrido para Joanes}

Esse sistema localiza-se na ilha de Marajó, no estado do Pará e tem como aplicação a eletrificação rural, com o fornecimento de energia elétrica para uma vila de 150 consumidores.

É um sistema composto de quatro turbinas eólicas de $6 \mathrm{~kW}$, um sistema fotovoltaico de 10,2 kWp, um banco de baterias de 1000 Ah de capacidade e um 
Pequeno Porte

conversor $\mathrm{CA} / \mathrm{CC}$ rotativo. Este sistema foi conectado à rede elétrica do sistema diesel de Salvaterra que tem capacidade instalada de 1,2 MVA. 


\section{CÉlula a Combustível}

As células a combustível são dispositivos que convertem a energia química de um combustível (hidrogênio) e um oxidante (oxigênio) diretamente em energia elétrica, sem que haja combustão. Estes dispositivos são semelhantes às baterias (pilhas) - são compostos de dois eletrodos (um positivo, o cátodo e outro negativo, o ânodo) com um condutor eletrolítico entre eles -, diferenciando-se apenas pelo fato de possuírem uma operação contínua devido à alimentação constante de um combustível.

Existem vários combustíveis que podem ser utilizados como fonte de energia em uma célula a combustível, porém, no atual estágio de desenvolvimento desta tecnologia, o hidrogênio é o que apresenta o melhor rendimento, além de que ao ser utilizado, o hidrogênio libera energia sem gerar poluentes. A reação química resultante da operação gera, além de energia, calor e vapor de água pura.

O hidrogênio pode ser obtido a partir da eletrólise da água, de hidrocarbonetos leves (cadeias carbônicas situadas entre o metano e a nafta), da gaseificação de resíduos agrícolas, da dissociação do metanol, do etanol e do gás natural. Recentemente, pesquisas concentram seus esforços para o desenvolvimento de células que operam através de metanol direto na célula - DMFC ("Direct Methanol Fuel Cells"). Estas pesquisas também começam a ser direcionadas para 0 uso de etanol com a mesma finalidade. Se este desenvolvimento for viável na prática, o Brasil se tornará um dos países com maior potencial para o uso da tecnologia de célula a combustível.

Com o grande desenvolvimento na área de materiais nos últimos 15 anos, a tecnologia em células a combustível, associada à crescente exigência de baixo impacto ambiental, tornou-se bastante promissora no cenário mundial de energia. Em médio prazo, elas representam uma alternativa tanto para motores de combustão (unidades móveis), como para geradores de energia de médio porte (100 kW) e até plantas de alguns MW de potência (unidades estacionárias). 


\subsection{Princípio de funcionamento}

A conversão, da energia química em energia elétrica nas células a combustível, ocorre por meio de duas reações eletroquímicas parciais de transferência de carga em dois eletrodos separados por um eletrólito apropriado, ou seja, a oxidação de um combustível no ânodo e a redução de um oxidante no cátodo. Na medida em que os eletrodos são supridos com os gases reagentes (hidrogênio para o ânodo e oxigênio para o cátodo) aparece uma diferença de potencial entre os mesmos que, em circuito aberto, resulta da ordem de 1,0V. Escolhendo-se o hidrogênio como combustível e o oxigênio (puro ou do próprio ar atmosférico) como oxidante, tem-se na denominada célula ácida, a formação de água e a produção de calor, além da liberação de elétrons para um circuito externo, que podem gerar trabalho elétrico. As reações nos eletrodos são:

$$
\begin{gathered}
\text { Ânodo: } \mathrm{H}_{2} \rightarrow 2 \mathrm{H}^{+}+2 \mathrm{e}^{-} \\
\text {Cátodo: } 1 / 2 \mathrm{O}_{2}+2 \mathrm{H}^{+} \rightarrow \mathrm{H}_{2} \mathrm{O} \\
\text { Reação Total: } \mathrm{H}_{2}+1 / 2 \mathrm{O}_{2} \rightarrow \mathrm{H}_{2} \mathrm{O}
\end{gathered}
$$

A figura 5.1 esquematiza o funcionamento da célula a combustível. 


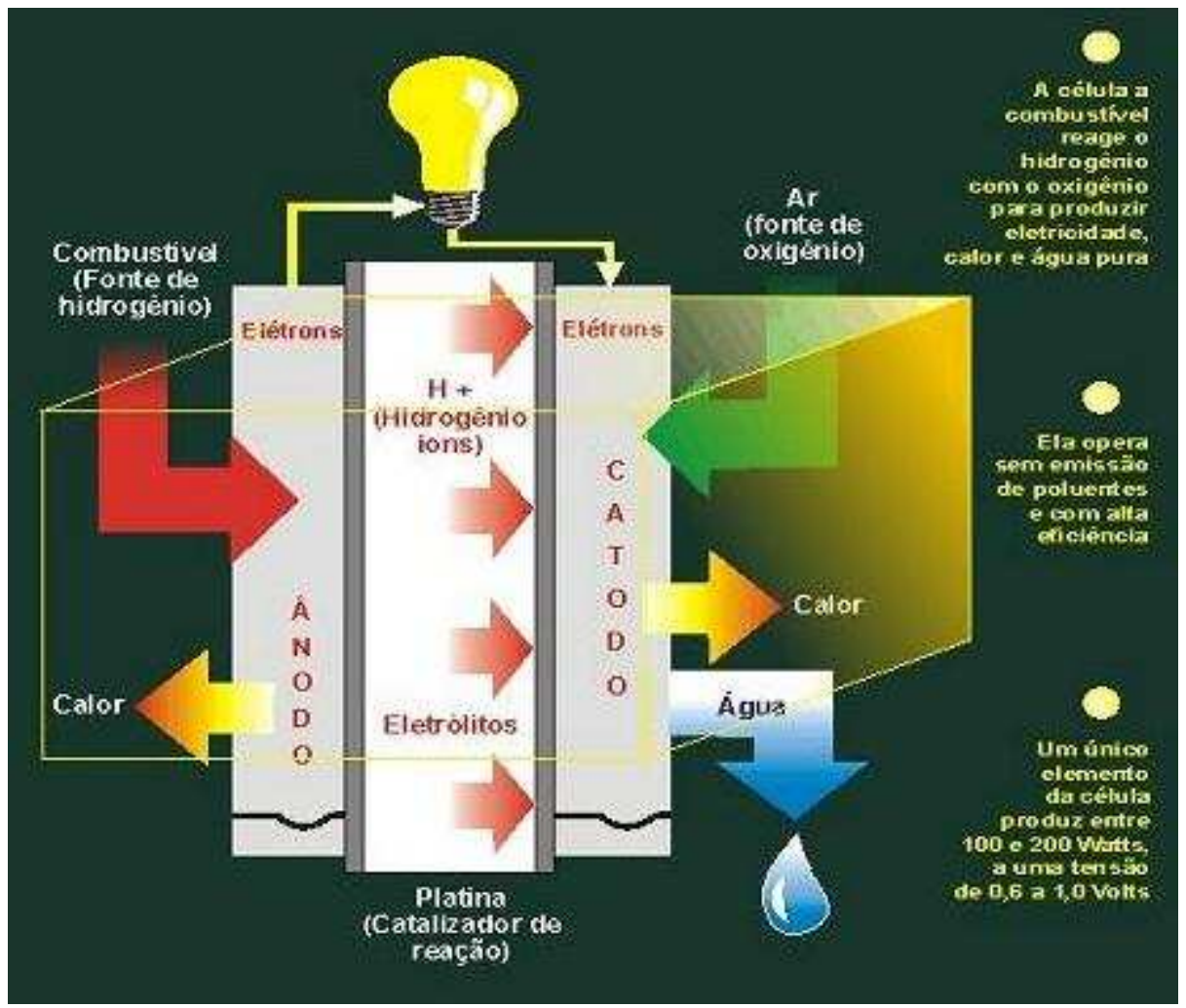

Figura 5.1 - Funcionamento da Célula a Combustível

(Fonte: http://www.copel.com.br)

\subsection{Eficiência}

A eficiência termodinâmica das células a combustível é dada pelo quociente entre a energia livre de reação e entalpia da reação, usualmente supera os $90 \%$. Entretanto, a eficiência elétrica prática é menor, pelo fato de o potencial da célula ser menor que o teórico.

A eficiência tem uma fraca dependência da temperatura, quando comparada à eficiência dada pelo ciclo de Carnot. Sendo assim, as células a combustível possibilitam a obtenção de altas eficiências, ou seja, um melhor aproveitamento do combustível, mesmo em baixas temperaturas. Na prática, obtêm-se eficiências elétricas de $45 \%$ a $60 \%$. Quando a temperatura de operação da célula não for muito baixa, o calor produzido pode ser aproveitado e a eficiência total pode ser de $80 \%$. 


\subsection{Vantagens e limitações das células combustível}

A eficiência, isoladamente, não é a principal vantagem de sistemas de geração de energia com células a combustível, e sim, o seu inerente fator ecológico, com baixíssima geração de poluentes, além de serem silenciosas, compactas e de fácil manutenção. Dentre as inúmeras vantagens que tais dispositivos apresentam destacam-se:

- Elevada eficiência: A conversão de energia química em energia elétrica na célula é direta resultando em elevada eficiência global.

- Modularidade: Sendo modulares, as células podem ser construídas em várias dimensões e configurações (de $100 \mathrm{~W}$ a vários MW).

- Operação limpa e silenciosa: Os subprodutos da conversão de energia estão muito abaixo dos padrões internacionais.

- Resposta rápida de carga: A capacidade de resposta a uma mudança de carga de vazio a potência total é de 1 segundo, o que pode ser comparado a outros sistemas eletroquímicos (pilhas, baterias) ou capacitores.

- Flexibilidade no uso de combustíveis: Uma variedade de combustíveis pode ser utilizada nas células, conforme descrições acima.

- Grande capacidade energética: Ao contrário dos outros sistemas eletroquímicos de conversão de energia combustível, fornecem energia elétrica enquanto a elas são fornecidos reagentes.

Por estas razões, vislumbra-se um mercado para sistemas de célula a combustível para geração de energia, com aplicações localizadas de até alguns MW de potência como em hospitais, condomínios residenciais, etc. As vantagens aumentam quando se tem por finalidade a geração de energia móvel, caso das células de baixa temperatura, onde sua eficiência fica bem acima dos motores convencionais. 
Pequeno Porte

Apesar das inúmeras vantagens que as células apresentam, são encontradas algumas limitações para a aplicação destes sistemas: uma dessas limitações é o armazenamento do combustível (o hidrogênio).

\subsection{Aplicações}

A primeira célula a combustível adquirida no hemisfério sul opera em Curitiba, desde 2001, trazida para um projeto conjunto de pesquisa entre a COPEL e o Lactec (Instituto de Tecnologia para o Desenvolvimento).

Por meio de contrato de pesquisa firmado com a COPEL, que vai usar os equipamentos, o Lactec (parceria COPEL, UFPR, FIESP, Associação Comercial e Instituto de Engenharia do Paraná) adquiriu 3 células a combustível com o objetivo de conhecer seu funcionamento e familiarizar-se com a tecnologia utilizada. Existem cerca de 200 equipamentos do gênero em operação nos Estados Unidos, no Canadá e em alguns países da Europa.

Os equipamentos adquiridos têm capacidade de produzir $200 \mathrm{kWh}$ de energia elétrica e o equivalente a $200 \mathrm{kWh}$ de energia térmica; o calor gerado pela reação química seria suficiente para elevar em $50^{\circ} \mathrm{C}$ a temperatura de 3.500 litros de água por hora. A primeira célula se encontra instalada no Pólo Operacional da COPEL, no bairro de Mossunguê e sua eletricidade alimenta o Centro de Processamento de Dados da Concessionária, cujo consumo médio é de $120 \mathrm{kWh}$. A empresa estuda a viabilidade de aproveitar a geração excedente na própria rede elétrica do Pólo. A energia térmica é aproveitada para aquecer os seis mil litros de água consumidos diariamente no refeitório do Pólo. As demais células deverão ser instaladas no Campus do Centro Politécnico da UFPR e em um dos hospitais públicos da região Metropolitana de Curitiba.

Por ser uma fonte dedicada e localizada próxima do ponto de consumo, a eletricidade provida pela célula a combustível pode ser chamada tecnicamente de "energia pura". Ela é de altíssima qualidade porque esta livre de interferências do meio ambiente (descargas atmosféricas ou perdas decorrentes da distância) e tem baixo risco de interrupção. Entre os usuários potenciais desse tipo de energia estão os centros de processamento de dados, indústrias automatizadas e hospitais. 
Pequeno Porte

O custo unitário dos equipamentos ainda é bastante elevado, porém, por se tratar de uma tecnologia relativamente recente, ambientalmente correta existem expectativas de que seu custo possa ser bastante reduzido futuramente, ao ponto de fazer da célula a combustível uma alternativa viável à extensão das redes de energia elétrica convencionais. 


\section{DIMENSIONAMENTO DE UM SISTEMA}

\section{FOTOVOLTAICO DE PEQUENO PORTE}

O dimensionamento de sistemas fotovoltaicos baseia-se, em alguns casos, em características médias dos componentes e valores típicos de radiação solar. Devem ser consideradas, também, as perdas relativas aos componentes, ou seja, o Balanço do Sistema (BOS) que envolve os condutores, os diodos de bloqueio, as proteções, etc.

Existem alguns métodos simplificados de dimensionamento que se aplicam a sistemas de pequeno porte - sistemas para iluminação residencial, por exemplo que são caracterizados por planilhas baseadas na operação do sistema em um dia típico. Usualmente, os sistemas de pequeno porte são constituídos dos componentes mostrados na figura 6.1 .

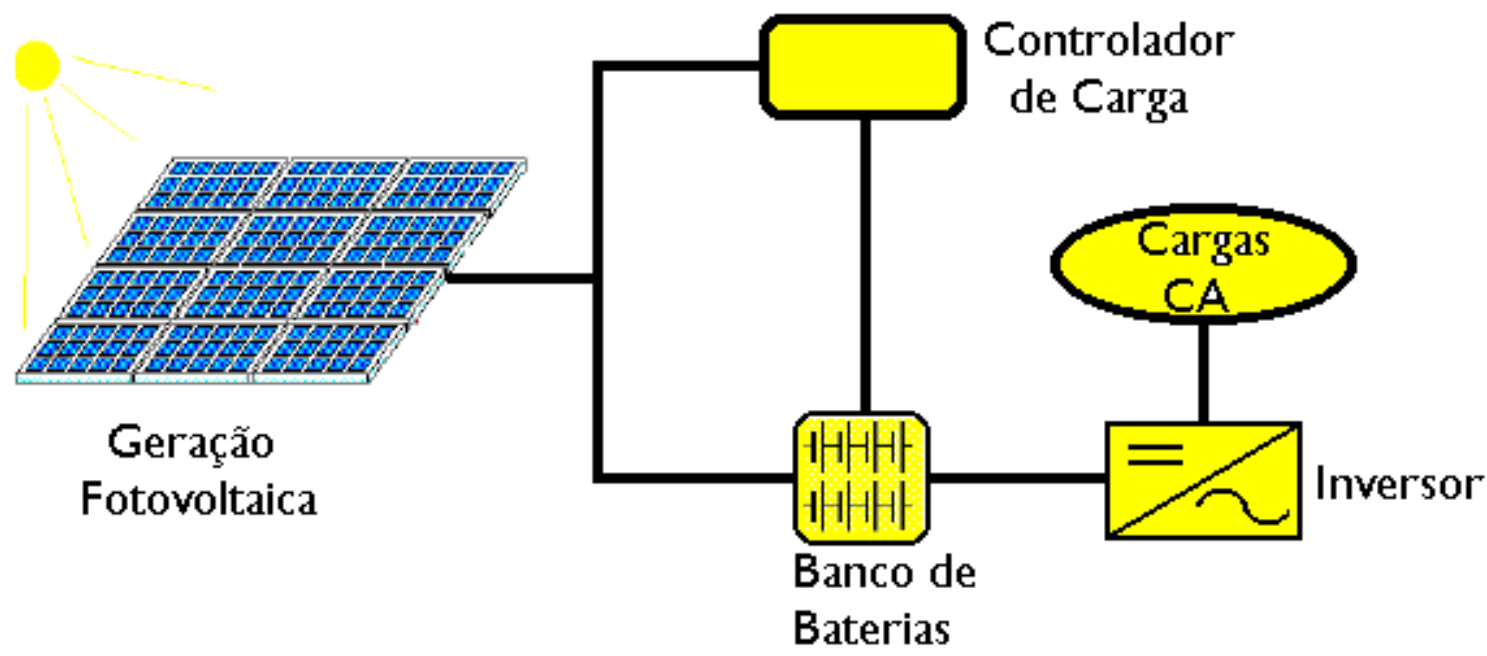

Figura 6.1 - Exemplo de configuração de um sistema fotovoltaico de pequeno porte

Um sistema constituídos pelos componentes da figura 6.1, doado pelo Ministério de Minas e Energia, através do PRODEEM, em parceria com o CEPEL, foi instalado no prédio dos laboratórios do departamento de Engenharia Elétrica - o SG 11. Foram, então, desenvolvidas as etapas de dimensionamento de um sistema utilizado para iluminação. 
O método utilizado para o dimensionamento do sistema de iluminação do corredor superior do SG 11, e que pode ser utilizado para qualquer sistema de pequeno porte, baseia-se nas planilhas do Manual "Stand Alone Photovoltaic Systems - A Handbook of Recommended Design Practices", produzido pelo Laboratório Nacional Sandia, com algumas adaptações em função das características locais. No decorrer deste capítulo, todas as etapas envolvidas em um projeto de sistemas fotovoltaicos serão descritas exemplificando o sistema em questão.

\subsection{Avaliação do recurso solar}

Para o cálculo da energia gerada por um painel é necessário quantificar a radiação global incidente sobre o mesmo. No Brasil, as grandezas comumente medidas são o número de horas de insolação e a radiação global no plano horizontal, que costuma ser especificada em termos de energia por unidade de área $\left(\mathrm{Wh} / \mathrm{m}^{2}\right)$. A forma mais comum de apresentação dos dados de radiação é através de valores médios mensais para a energia acumulada ao longo do dia.

Uma forma conveniente de se expressar o valor acumulado de energia solar ao longo de um dia é através do número de horas de Sol Pleno $\left[\left(\mathrm{kWh} / \mathrm{m}^{2}\right) /\left(1 \mathrm{~kW} / \mathrm{m}^{2}\right)\right]$. Esta grandeza reflete o número de horas em que a radiação solar deve permanecer constante e igual a $1 \mathrm{~kW} / \mathrm{m}^{2}$ de forma que a energia resultante seja equivalente à energia acumulada para o dia e local em questão. O número de horas de Sol Pleno é um parâmetro utilizado no método de dimensionamento do projeto de iluminação descrito neste capítulo. Este não é o único método existente para dimensionamento de sistemas fotovoltaicos, existem outros métodos mais simples e que não utilizam o Sol Pleno como parâmetro.

Para o projeto em questão, foram utilizados os dados de radiação solar calculados pelo programa SUNDATA, disponível na página do CRESESB na internet (http://www.cresesb.cepel.br/sundatn.htm). Além destes, foram também utilizados os dados de radiação obtidos do Atlas Solarimétrico do Brasil elaborado pelo Grupo de Pesquisas em Fontes Alternativas de Energia (Grupo FAE) da Universidade Federal de Pernambuco (UFPE) - tabela 6.1. 
Tabela 6.1 - Insolação Diária/Radiação Solar Global Diária no Plano Horizontal Médias Mensais - Brasília - Distrito Federal

(Fonte - Atlas Solarimétrico do Brasil, Editora Universitária da UFPE)

\begin{tabular}{|c|c|c|c|c|}
\hline MÊS & $\begin{array}{c}\text { Insolação } \\
\text { Diária } \\
(\text { horas) }\end{array}$ & $\begin{array}{c}\text { Radiação Solar Global } \\
\text { Diária } \\
\left(\mathrm{kWh} / \mathrm{m}^{2}\right)^{(2)}\end{array}$ & $\begin{array}{c}\text { Radiação Solar Global } \\
\text { Diária } \\
\left(\mathrm{kWh} / \mathrm{m}^{2}\right)^{(3)}\end{array}$ & $\begin{array}{c}\text { Radiação Solar Global } \\
\text { Diária } \\
\left(\mathrm{kWh} / \mathrm{m}^{2}\right)^{(4)}\end{array}$ \\
\hline JAN & 5,08 & 4,44 & 5,07 & 4,44 \\
\hline FEV & 5,58 & 4,22 & 5,12 & 4,22 \\
\hline$M A R$ & 5,84 & 4,45 & 5,02 & 3,29 \\
\hline$A B R$ & 6,70 & 4,22 & 4,94 & 4,22 \\
\hline$M A I$ & 7,56 & 4,16 & 4,67 & 4,16 \\
\hline$J U N$ & 8,45 & 3,66 & 4,58 & 3,66 \\
\hline$J U L$ & 8,56 & 4,46 & 4,85 & 4,46 \\
\hline$A G O$ & 8,48 & 4,69 & 5,22 & 4,69 \\
\hline SET & 6,77 & 4,32 & 5,14 & 4,32 \\
\hline OUT & 5,43 & 3,88 & 5,17 & 3,88 \\
\hline NOV & 4,75 & 4,16 & 4,85 & 4,16 \\
\hline$D E Z$ & 4,45 & 4,54 & 4,77 & 4,54 \\
\hline
\end{tabular}

FONTES

(1) Normas Climatológicas (1961-1990), Departamento Nacional de Meteorologia, Ministério da Agricultura e Reforma Agrária, Brasília, DF, 1992.

(2) FUNARI, F.L, Insolação, Radiação Solar Global e Radiação Líquida no Brasil, Dissertação de Mestrado do Departamento de Geografia da Universidade de São Paulo, 1983.

(3) Boletim de Radiação Solar Trimestral, Ministério da Agricultura, Instituto Nacional de Meteorologia, 1978 a 1990.

(4) VILLA NOVA, N. A. e SALLATI, E., Radiação Solar no Brasil, Anais do I Simpósio Anual da Academia de Ciências do Estado de São Paulo, pp. 27-61, 1977.

(5) Valores medios de irradiación solar sobre suelo horizontal, Centro de Estudios de la Energia Solar, PROGENSA, Argentina, 1993.

\subsubsection{Potencial solar - SUNDATA}

O SUNDATA destina-se ao cálculo da radiação solar diária média mensal em qualquer ponto do território nacional, baseando-se nos bancos de dados do Centro de Estudos de Energia Solar (CENSOLAR). O SUNDATA também é uma importante ferramenta utilizada na identificação da inclinação mais adequada para o painel fotovoltaico.

Os valores de radiação solar fornecidos pelo programa são em $\mathrm{kWh} / \mathrm{m}^{2}$.dia no plano horizontal e correspondem às médias mensais para os doze meses do ano. São fornecidos, também, valores de radiação solar convertidos do plano horizontal para o plano inclinado com diferentes ângulos em relação ao plano horizontal: o ângulo igual ao valor da latitude da localidade; o ângulo que fornece a maior média 
Pequeno Porte

diária anual de radiação e o ângulo que fornece o maior valor mínimo mensal de radiação; que são geralmente as inclinações mais favoráveis para a instalação dos painéis fotovoltaicos - tabela 6.2.

O valor de10ำ para a inclinação é considerado ótimo por fornecer o maior mínimo para a radiação mensal. A única restrição imposta pelo SUNDATA é que ele assume um consumo mensal constante ao longo do ano.

Tabela 6.2 - Radiação Solar Diária Média Mensal

$$
\text { Brasília - Distrito Federal }
$$

(Fonte - http://www.cresesb.cepel.br/sundatan.htm)

\begin{tabular}{|c|c|c|c|c|}
\hline MÊS & $\begin{array}{c}\text { Radiação Solar } \\
\text { Diária } \\
\text { (kWh/m².dia) } \\
\text { Plano Horizontal }\end{array}$ & $\begin{array}{c}\text { Radiação Solar } \\
\text { Diária } \\
\left(\mathrm{kWh} / \mathrm{m}^{2} . d i a\right) \\
\left(\text { Latitude }-16^{\circ}\right)\end{array}$ & $\begin{array}{c}\text { Radiação Solar } \\
\text { Diária } \\
\left(\mathrm{kWh} / \mathrm{m}^{2} . \text { dia }\right) \\
\left(\text { Maior Média }-20^{\circ}\right)\end{array}$ & $\begin{array}{c}\text { Radiação Solar } \\
\text { Diária } \\
\text { (kWh/m².dia) } \\
\text { (Maior Mínimo - } \\
10^{\circ} \text { ) }\end{array}$ \\
\hline JAN & 4,67 & 4,38 & 4,27 & 4,51 \\
\hline$F E V$ & 5,58 & 5,36 & 5,26 & 5,48 \\
\hline$\overline{M A R}$ & 4,53 & 4,55 & 4,52 & 4,57 \\
\hline$A B R$ & 5,00 & 5,35 & 5,4 & 5,26 \\
\hline$M A I$ & 4,72 & 5,39 & 5,5 & 5,18 \\
\hline JUN & 4,75 & 5,65 & 5,82 & 5,36 \\
\hline JUL & 4,97 & 5,84 & 5,99 & 5,56 \\
\hline$A G O$ & 5,5 & 6,11 & 6,2 & 5,92 \\
\hline SET & 5,25 & 4,58 & 5,41 & 5,39 \\
\hline OUT & 4,69 & 4,48 & 4,52 & 4,65 \\
\hline $\mathrm{NOV}$ & 4,75 & 4,48 & 4,38 & 4,61 \\
\hline$\overline{D E Z}$ & 4,72 & 4,39 & 4,27 & 4,54 \\
\hline
\end{tabular}

Comparando-se os valores de radiação solar diária para o plano horizontal das tabelas 6.1 e 6.2, através do gráfico da figura 6.2, observa-se que não existem grandes diferenças. Como as fontes de dados são diferentes, é possível que elas possuam critérios diversos para a obtenção destes dados. 


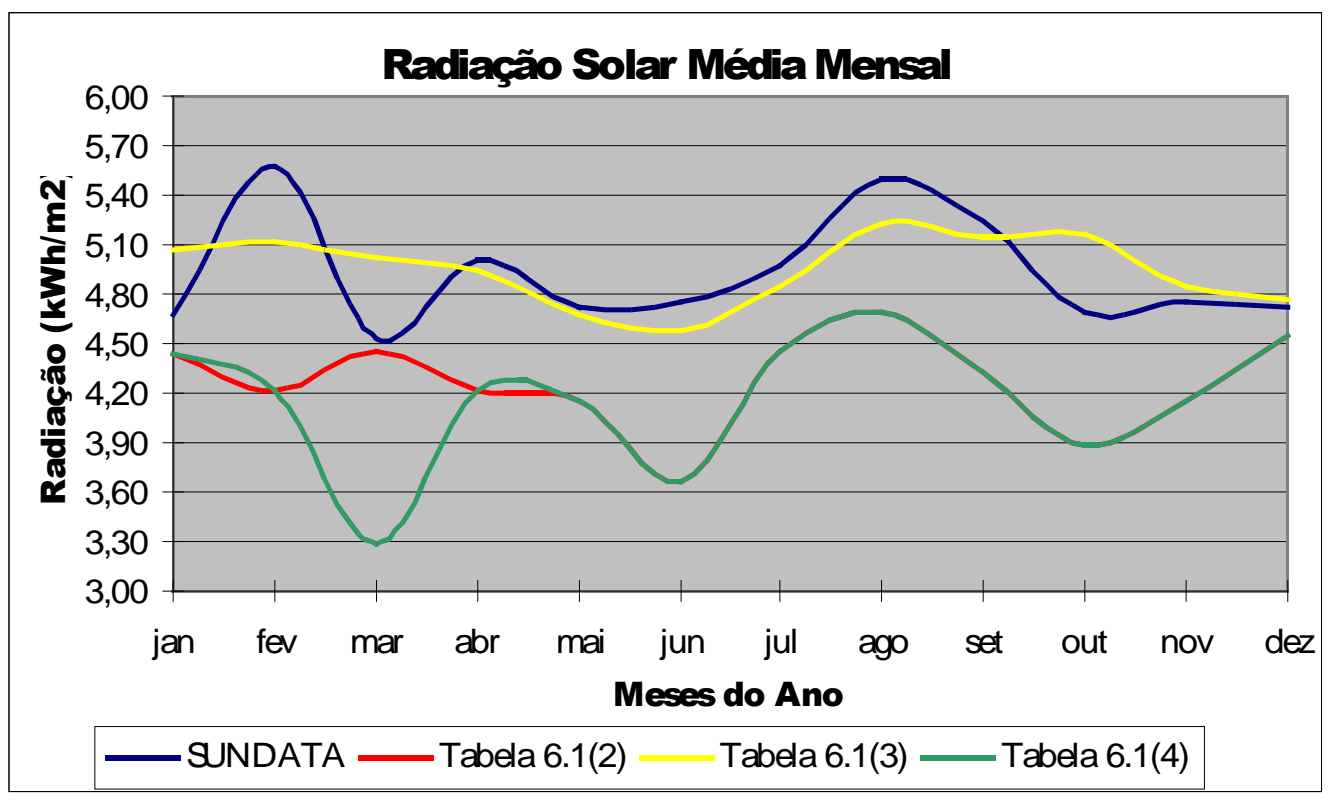

Figura 6.2 - Gráfico de Radiação Solar Diária

\subsubsection{Radiação solar em superfícies inclinadas}

O cálculo da intensidade de radiação solar em superfícies inclinadas é um procedimento trabalhoso, pois requer um elevado número de operações aritméticas envolvidas, além de serem necessários modelos de distribuição temporal e espacial da radiação solar. A Universidade Federal do Rio Grande do Sul (UFRGS) possui um programa elaborado no Laboratório de Energia Solar do Grupo de Estudos Térmicos e Energéticos (GESTE) capaz de calcular a radiação solar incidente em superfícies de diferentes orientações - o RADIASOL. Este programa pode ser obtido no própria página do GESTE na internet (http://www.geste.mecanica.ufrgs.br) e foi utilizado para a obtenção de dados para o projeto em questão.

No RADIASOL, os cálculos são realizados através de rotinas que determinam o efeito da inclinação da superfície receptora e da anisotropia da radiação solar em suas componentes direta e difusa. $O$ ponto de partida para quase todos os cálculos é a informação da radiação solar global diária sobre a superfície horizontal $(\mathrm{H})$ acompanhada da correspondente latitude. $\mathrm{O}$ valor de $\mathrm{H}$ pode ser extraído do banco de dados que o acompanha, sendo a radiação solar global diária estimada em valores médios mensais. Este banco de dados contém informações de 
Pequeno Porte

cerca de 200 estações meteorológicas no Brasil, sendo que os dados da América Latina são originados de estimativas da Organização Latino-americana de Energia (OLADE) a partir de medidas de insolação (número de horas de sol brilhante).

Normalmente, para obter o melhor ângulo de inclinação dos painéis fotovoltaicos, utiliza-se a seguinte regra prática, obtida através de cálculos computacionais detalhados que pressupõem uma razoável uniformidade dos valores de energia solar ao longo do ano:

$$
\text { Inclinação = latitude loca! 15ำ }
$$

Em Brasília, o ângulo correspondente à latitude é de 16ํ․ Então, os valores de inclinação analisados são $1^{\circ}$ e $31^{\circ}$, além do próprio ângulo correspondente á latitude $\left(16^{\circ}\right)$. Os dados de radiação $\left(\mathrm{em} \mathrm{Wh} / \mathrm{m}^{2}\right)$ para cada um destes valores de inclinação correspondentes a todos os meses do ano, fornecidos pelo RADIASOL, estão na tabela 6.3.

Tabela 6.3 - Dados de Radiação Solar - Brasília - DF

\begin{tabular}{|c|c|c|c|}
\hline MÊS & $\begin{array}{c}\text { Radiação Solar } \\
\left(W h / m^{2}\right) \\
1 \underline{o}\end{array}$ & $\begin{array}{c}\text { Radiação Solar } \\
\left(W h / m^{2}\right) \\
16^{\circ}\end{array}$ & $\begin{array}{c}\text { Radiação Solar } \\
\left(W h / m^{2}\right) \\
31^{\circ}\end{array}$ \\
\hline JAN & 4748 & 4600 & 4276 \\
\hline FEV & 5736 & 5582 & 5174 \\
\hline MAR & 4654 & 4626 & 4406 \\
\hline ABR & 5244 & 5468 & 5398 \\
\hline$M A I$ & 4978 & 5484 & 5666 \\
\hline JUN & 4978 & 5704 & 6080 \\
\hline JUL & 5196 & 5910 & 6266 \\
\hline AGO & 5742 & 6270 & 6420 \\
\hline SET & 5466 & 5574 & 5390 \\
\hline OUT & 4804 & 4728 & 4450 \\
\hline NOV & 4840 & 4696 & 4368 \\
\hline$D E Z$ & 4802 & 4632 & 4292 \\
\hline
\end{tabular}

Uma outra forma de se obter o melhor ângulo para a inclinação de painéis fotovoltaicos é a análise das curvas de radiação ao longo de um ano. Com os dados da tabela 6.3, obtém-se o gráfico da figura 6.3 que representa o comportamento da radiação solar ao longo de um ano. 


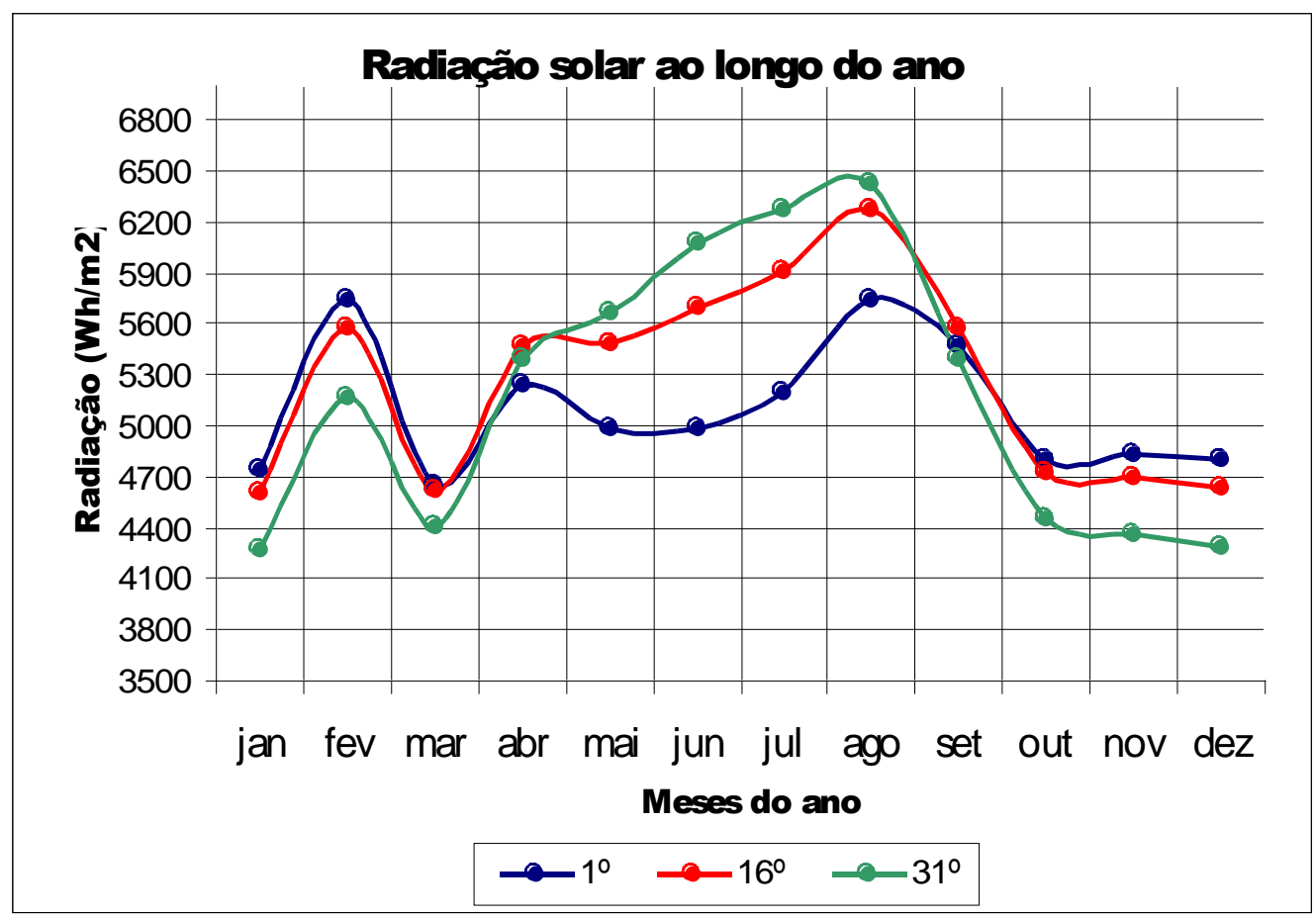

Figura 6.3 - Gráfico de radiação solar ao longo de um ano para diferentes valores de inclinação

Analisando o gráfico da figura 6.3, o ângulo referente à latitude do local é o mais indicado para a localização do arranjo fotovoltaico, pois os valores de radiação referentes a este ângulo apresentam uma melhor média mensal ao longo do ano. A energia anual produzida é máxima para este valor de inclinação.

Em alguns casos, sugere-se que a inclinação do painel seja igual ao ângulo da latitude acrescido de 15 (31을 para o caso em questão), para que haja compensação nos meses de inverno, quando o sol se situa a uma latitude mais baixa. Conforme o gráfico, nos meses de inverno os valores de radiação são realmente mais elevados para uma inclinação de $31^{\circ}$.

Existem, então, pelo menos três formas de se determinar o melhor ângulo de inclinação de um painel fotovoltaico, cada uma delas indicando valores diferentes. O valor escolhido para a inclinação do painel montado no SG11 foi de $31^{\circ}$. 


\subsection{Avaliação do comportamento das cargas}

Os sistemas fotovoltaicos geram eletricidade em corrente contínua, que se diferencia da eletricidade fornecida pela rede elétrica convencional pelo fato desta ser distribuída em corrente alternada.

Embora existam equipamentos disponíveis que operam diretamente em corrente contínua, normalmente os que se encontram no mercado são projetados para funcionar em corrente alternada, nas tensões de $110 \mathrm{~V}$ e $220 \mathrm{~V}$.

A principal aplicação da energia gerada por pequenos sistemas fotovoltaicos é, em geral, a iluminação. No momento de se escolher as lâmpadas mais adequadas para uma determinada aplicação, devem ser consideradas a eficiência, os requisitos de potência além dos custos.

Para o dimensionamento do sistema de geração deve-se analisar a demanda de energia pela carga, para que se possa identificar possíveis sazonalidades, reduzir os custos do sistema e prevenir contra efeitos de possíveis variações no comportamento da carga.

A forma mais comum de se especificar uma carga é através do seu consumo diário de energia. No dimensionamento das cargas, estas são avaliadas através do produto do consumo nominal dos equipamentos (em ampères) pelo tempo de utilização diária (em horas). Pode-se, também, expressar o consumo em Wh, porém como a tensão do sistema tende a variar durante o processo (diferença na tensão das baterias para os períodos de carga e descarga, por exemplo), recomenda-se expressá-lo em Ah.

Outro fator importante na avaliação da carga é a determinação dos valores extremos de consumo (máximo e mínimo), para que os componentes possam ser dimensionados segundo as condições críticas de operação. 


\subsection{Dimensionamento do sistema de}

\section{armazenamento}

As baterias são os equipamentos de armazenamento de energia elétrica de melhor relação custo versus benefício, embora existam outras alternativas. Elas são conhecidas por serem uma conveniente e eficiente forma de armazenamento de energia.

Os parâmetros mais importantes para o dimensionamento de um banco de baterias são a eficiência, a máxima profundidade de descarga (para ciclos diários e esporádicos) e a autonomia do sistema.

\subsubsection{Eficiência}

Eficiência é a relação entre a saída útil e a entrada. Existem duas formas de se expressar a eficiência de uma bateria:

- Eficiência de Ampère-hora (Ah) ou Coulômbica: É a relação entre a quantidade de Ah retirada de uma célula - unidade eletroquímica básica de uma bateria - durante a descarga e a quantidade necessária para restaurar o estado de carga inicial. Aproxima-se dos 100\%.

- Eficiência de Watt-hora (Wh) ou de Energia: É a relação entre a energia retirada da bateria durante o processo de descarga e a energia necessária para restaurar o estado de carga inicial. Situa-se em torno de $85 \%$.

A eficiência sofre redução quando a bateria está com seu estado de carga próximo à carga plena (100\%). Além de que, baixas temperaturas também reduzem a eficiência das baterias.

\subsubsection{Máxima profundidade de descarga}

A profundidade de descarga indica, em termos percentuais, quanto da capacidade nominal da bateria foi retirado a partir do estado de plena carga. Este é 
Pequeno Porte

um dos parâmetros utilizados pelos fabricantes de baterias para estimar a capacidade de vida cíclica da bateria.

A operação de uma bateria, usada em sistemas fotovoltaicos, deve atender a dois tipos de ciclos: os ciclos rasos diários e os ciclos profundos, que correspondem aos períodos críticos de geração solar (tempo nublado e períodos de inverno). Os ciclos profundos ocorrem quando o carregamento não é suficiente para repor a quantidade de carga usada pelos aparelhos durante todo o dia. Quanto mais profundo o ciclo, mais curta é a vida útil da bateria.

\subsubsection{Autonomia do sistema}

O número de dias sem Sol é uma previsão do maior período possível de consumo de energia com geração solar insuficiente para repor o estado de carga inicial das baterias. Para o dimensionamento do banco de baterias, deve-se considerar a quantidade de dias consecutivos que as baterias terão de atender a carga nos períodos em que o arranjo fotovoltaico não estiver gerando energia.

\subsection{Dimensionamento da geração fotovoltaica}

Tendo obtido os dados de radiação solar e sabendo qual é a expectativa de demanda de energia para o sistema, pode-se dimensionar a quantidade de painéis fotovoltaicos. É importante analisar os dados técnicos de diversos tipos de painéis disponíveis, para efetuar tal dimensionamento, além de considerar aspectos como vida útil, confiabilidade e custo. A figura 6.4 ilustra alguns dos tipos de painéis fotovoltaicos fabricados pela Kyocera e pela Siemens comercialmente disponíveis. 


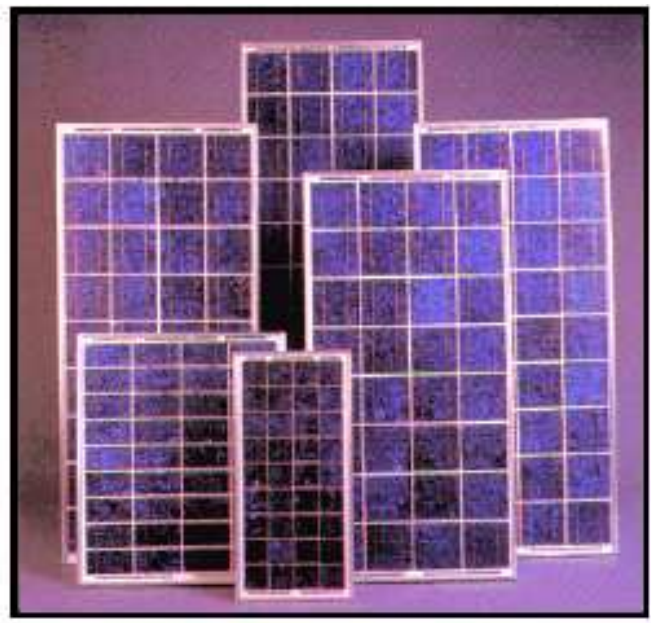

Painéis Kyocera

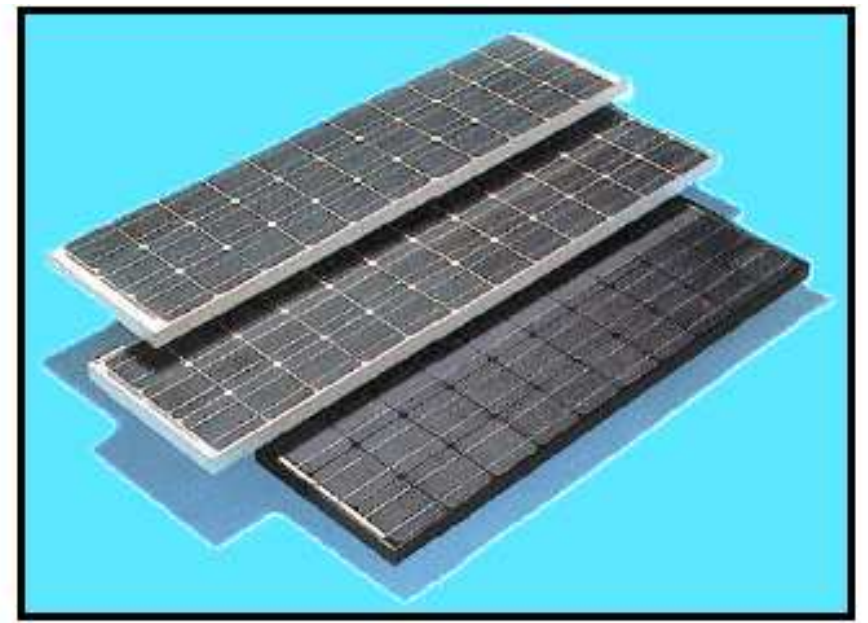

Painéis Siemens

Figura 6.4 - Alguns painéis Kyocera e Siemens disponíveis comercialmente

(Fonte: "Energia Solar - Princípios e Aplicações")

Alguns dos fatores que influenciam na escolha do tipo e da quantidade de painéis a serem utilizados são a tensão nominal do sistema, a curva característica $I x V$ do sistema e o custo e a expectativa de vida para o painel.

O processo para o dimensionamento dos painéis consiste em determinar a inclinação do arranjo e o mês crítico para o dimensionamento, além de determinar o número total de painéis. Os seguintes parâmetros também devem ser levados em consideração para o dimensionamento:

- O consumo calculado para a carga;

- A radiação solar global no plano do painel;

- A eficiência do banco de baterias;

- As perdas causadas por componentes adicionais;

- O valor típico de corrente correspondente ao ponto de potência máxima;

- A tensão de operação, que para sistemas com armazenamento é imposta pela bateria e depende da corrente, do estado de carga e da temperatura. 


\subsection{Especificação dos controladores de}

\section{carga}

Os controladores de carga são incluídos nos sistemas fotovoltaicos com os objetivos de facilitar a máxima transferência de energia do arranjo fotovoltaico para as baterias e de protegê-las contra cargas e descargas excessivas.

Os controladores devem desconectar o arranjo fotovoltaico quando a bateria atingir carga plena e interromper o fornecimento de energia quando o estado de carga da bateria atingir um nível mínimo de segurança. Alguns controladores também monitoram o desempenho do sistema fotovoltaico, tal como a corrente e a tensão de carregamento da bateria ou da carga.

Os tipos mais comuns de controladores estimam e controlam o estado de carga das baterias medindo a tensão instantânea nos seus terminais e comparandoos a dois limites. Para as baterias de chumbo-ácido, por exemplo, a $25^{\circ} \mathrm{C}$, o limite superior se situa entre 2,3V e 2,5V por célula e o limite inferior está entre $1,9 \mathrm{~V}$ e 2,1V por célula.

Para se especificar um controlador de carga é importante saber o tipo de bateria a ser utilizada e o regime de operação do sistema. Determina-se, também, a tensão e a corrente de operação - nominais - do sistema.

Outras características também são desejáveis para a especificação de um controlador, porém nem sempre são disponíveis nos modelos mais comuns. São elas:

- Proteção contra corrente reversa: A maioria dos controladores incluem um mecanismo que impede o fluxo de corrente da bateria para o arranjo fotovoltaico durante a noite, quando a tensão de circuito aberto do arranjo é inferior à tensão da bateria.

- Desconexão da carga (LVD): Alguns controladores de carga evitam que as baterias tenham um descarregamento excessivo, desconectando as cargas alimentadas pelo sistema fotovoltaico. 
Pequeno Porte

O ponto de desconexão da carga é chamado de LVD, abreviatura da expressão Low Voltage Disconnect. Valores típicos de profundidade de descarga utilizados para LVD são, para as baterias de ciclo raso, de $20 \%$ a $40 \%$ e, para as baterias de ciclo profundo, em torno de $80 \%$.

- Indicações visuais: Muitos controladores de carga têm um diodo emissor de luz (LED) que é aceso quando as baterias estão completamente carregas, outro para mostra quando o arranjo fotovoltaico está carregando as baterias e outro para mostrar quando o estado de carga das baterias está muito baixo.

\subsection{Especificação dos inversores}

Os inversores são componentes responsáveis pela conversão de corrente contínua em corrente alternada. Estes equipamentos devem dissipar o mínimo de potência, reduzindo perdas, e devem produzir uma tensão com baixa quantidade de harmônicos. Usualmente, os inversores operam com tensões de entrada de $12 \mathrm{~V}, 24$ $\mathrm{V}, 48 \mathrm{~V}$ ou $120 \mathrm{~V}$ em corrente contínua que, geralmente, são convertidas em $120 \mathrm{~V}$ ou $240 \mathrm{~V}$, na freqüência de $60 \mathrm{~Hz}$ ou $50 \mathrm{~Hz}$.

Para especificar um inversor, é necessário considerar, além das tensões de entrada (CC) e de saída (CA), a potência exigida pelas cargas em operação normal e a potência de pico necessária para o acionamento das cargas, que deve ser pelo menos duas vezes maior que a potência nominal. Além disso, algumas características devem ser consideradas na especificação de um inversor:

- Forma de onda: A forma de onda de saída é uma indicação da qualidade do inversor e depende dos métodos de conversão e filtragem utilizados para suavizá-la e eliminar os harmônicos indesejáveis resultantes do processo de conversão.

- Eficiência da conversão de potência: É a relação entre as potências de saída e de entrada, para uma carga resistiva e normalmente, varia entre 50\% e 90\%. Deve-se projetar um inversor visando alcançar eficiência superior a 90\%.

- Potência nominal de saída: Potência que o inversor pode fornecer continuamente à carga. Um inversor deve ser especificado para fornecer uma 
potência superior às necessidades máximas das cargas conectadas, de forma a considerar algum aumento da demanda.

- Tensão de entrada: Em geral, a tensão de entrada é função da potência total fornecida pelo inversor às cargas CA. Normalmente, a tensão nominal de entrada do inversor aumenta com o aumento da demanda de carga, mantendo a corrente em níveis adequados.

A tensão de entrada CC pode ser fornecida pelas baterias. Se as baterias descarregam e a tensão diminui abaixo da tensão mínima especificada, a maioria dos inversores desliga-se automaticamente.

- Fator de potência: Os melhores inversores são projetados para compensarem as cargas indutivas - que possuem fator de potência que pode chegar a 0,5 - e manterem o fator de potência próximo da unidade, que maximiza a transferência de potência para a carga.

É desejável que as cargas tenham um fator de potência elevado, para que haja uma redução na corrente necessária para qualquer nível de potência. Os inversores devem ter uma fator de potência nominal compatível com o fator de potência desejado para as cargas.

O uso de inversores em sistemas fotovoltaicos ocasiona um aumento no dimensionamento do módulo fotovoltaico para compensar as perdas decorrentes da transformação de corrente contínua em corrente alternada (eficiência do inversor).

\subsection{Projeto elétrico}

O projeto elétrico inclui desde a escolha dos condutores até a especificação de dispositivos de proteção. Durante o dimensionamento de um sistema fotovoltaico deve-se considerar, também, a interconexão dos diversos componentes do sistema de forma eficiente, para evitar perdas de energia. 


\subsubsection{Diodos de proteção}

Os sistemas fotovoltaicos devem ser protegidos, sob o ponto de vista elétrico. Usualmente, são adotados dois tipos de diodo - o diodo de passo e o diodo de bloqueio.

Os diodos de passo têm como finalidade otimizar a captação de energia do arranjo e evitar danos aos módulos em períodos em que há sombreamento parcial do sistema. Estes diodos de passo (bypass) evitam que a corrente de um módulo seja limitada pelo elemento de pior desempenho.

Os diodos de passo são um caminho alternativo para a corrente e limitam a dissipação de potência no elemento sombreado. Isso ocorre porque a queda de tensão reversa no módulo ou na célula fica limitada pela tensão direta do diodo. $A$ maioria dos módulos inclui diodos de passo.

Já os diodos de bloqueio evitam fuga de corrente da bateria para o módulo fotovoltaico, em sistemas com armazenamento, durante o período noturno ou quando os níveis de radiação são muito baixos. Os diodos de bloqueio são instalados em série com a saída do módulo.

A especificação dos diodos é feita através da determinação da corrente direta de operação (função do número de módulos em paralelo) e da tensão reversa máxima (função do número de módulos em série).

Normalmente, os diodos de proteção são instalados em caixas de junção onde são feitas as interconexões entre os arranjos. A figura 6.5 ilustra com são feitas as conexões dos diodos de passo nas caixas de junção dos painéis da Kyocera. 

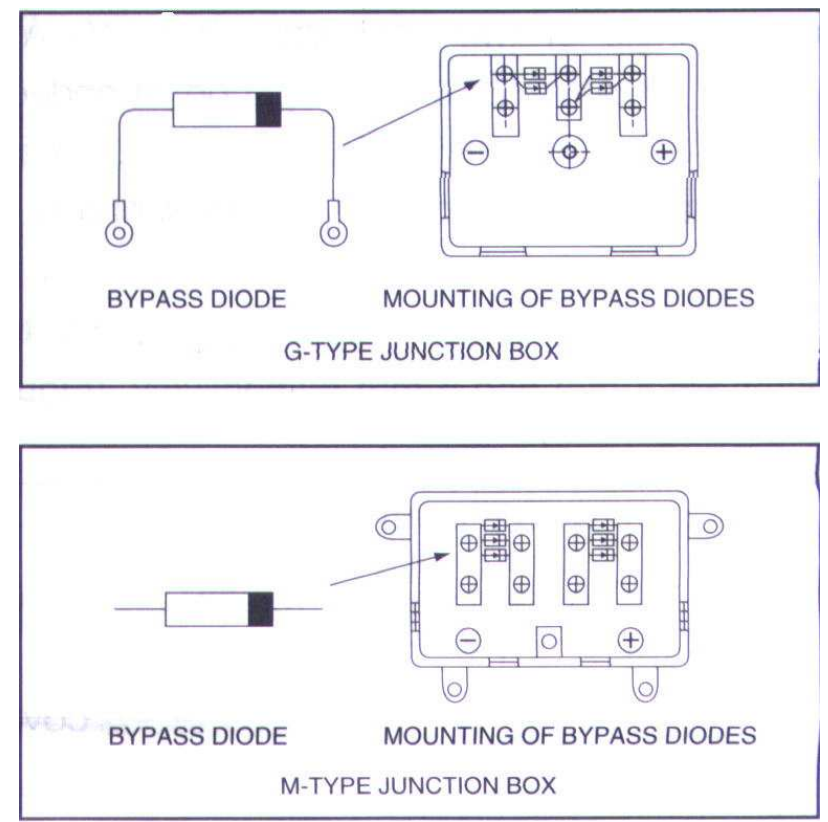

Figura 6.5 - Conexão de diodos de passo

\subsubsection{Fiação}

Todos os componentes de um sistema fotovoltaico devem ser interconectados por meio de condutores elétricos de bitola e tipo adequados. A bitola dos condutores depende, principalmente, do circuito onde eles estão instalados. Seu comprimento depende do posicionamento dos vários elementos do sistema, respeitando-se os limites permitidos para queda de tensão. Devem ser utilizados cabos elétricos de bitola e qualidade recomendadas pelos projetistas ou indicadas nos catálogos técnicos dos equipamentos fornecidos pelos fabricantes.

Os limites de perdas de tensão razoáveis para a condição crítica de operação são: 1\% entre controlador e baterias; 3\% para outros trechos individuais, por exemplo, entre módulo e controlador; e 5\% de perda total (entre o módulo até o usuário final). Estes percentuais são relativos à tensão nominal do sistema. Para a conexão do módulo ao controlador de carga deve-se utilizar condutores com capacidade para suportar pelo menos $125 \%$ da corrente nominal de curto-circuito do sistema fotovoltaico. [3] 
Estudo de Sistemas Fotovoltaicos de

Pequeno Porte

\subsubsection{Proteções}

A especificação dos dispositivos de proteção segue os mesmos procedimentos já normatizados e utilizados para sistemas elétricos em geral. Devese lembrar que muitos dos elementos dos sistemas fotovoltaicos, ou quase todos, operam em corrente contínua.

As chaves e os fusíveis são utilizados, em sistemas fotovoltaicos, para proteger as pessoas e os equipamentos de surtos de corrente e de tensão. Em alguns casos, as chaves e os fusíveis podem ser substituídos por disjuntores, por eles possuírem uma elevada confiabilidade.

As chaves oferecem a possibilidade de interromper o fluxo de corrente, em casos de emergência ou para manutenção. Os fusíveis e disjuntores permitem proteger os condutores, equipamentos e componentes nos casos de correntes elevadas causadas por curto-circuito no sistema, consumo elevado ou falha no aterramento. Estes elementos são utilizados entre o arranjo e o controlador de carga, entre a bateria e o controlador e nos circuitos de carga.

As chaves, os disjuntores e os fusíveis utilizados para proteger os componentes de um sistema fotovoltaico devem ser selecionados para operarem no lado CC, além de que devem ser selecionados em função da tensão e da corrente máximas admitidas. A corrente do arranjo fotovoltaico é limitada pela corrente de curto-circuito na condição de maior radiação, porém, para a especificação dos componentes que devem ser instalados entre o arranjo e o controlador de carga, recomenda-se utilizar um fator multiplicativo de segurança de 1,25.

Em sistemas fotovoltaicos é necessário fazer 0 aterramento dos equipamentos (moldura metálica dos módulos e caixas de equipamentos) e do sistema (circuito elétrico, geralmente através da linha de polaridade negativa) para impedir riscos de choque elétrico, estabilizar a tensão do sistema e proteger os equipamentos de correntes excessivas, decorrentes de uma falha.

Um sistema de aterramento elétrico fornece um caminho de baixa resistência de um ponto aterrado no sistema para a terra, onde a carga elétrica pode ser dissipada com segurança. 


\subsection{Planilhas de dimensionamento de um sistema de iluminação fotovoltaico}

Anteriormente, foram descritos quais são os parâmetros necessários para 0 dimensionamento dos diversos componentes que formam um sistema fotovoltaico para geração de energia elétrica. Nesta seção serão descritas as planilhas utilizadas para o dimensionamento do sistema em questão - sistema fotovoltaico de iluminação para atender parte do corredor superior do prédio do SG 11. Estas planilhas foram adaptadas a partir dos modelos presentes no Manual de Engenharia para Sistemas Fotovoltaicos e estão no Anexo $\boldsymbol{C}$. É importante ressaltar que as planilhas aqui descritas podem ser utilizadas para quaisquer sistemas de pequeno porte, não apenas o sistema em questão.

Inicialmente, as planilhas aqui descritas sugerem alguns valores típicos para a maioria dos parâmetros necessários para o dimensionamento dos componentes de um sistema fotovoltaico. Porém, existe a idéia de criação de um banco de dados contendo as informações relevantes de diversos fabricantes dos componentes, principalmente àquelas aplicáveis ao dimensionamento.

Deve-se observar que o dimensionamento em questão teve que se adaptar ao sistema fotovoltaico já existente. Normalmente, deve-se realizar primeiramente o dimensionamento das cargas que se deseja alimentar e, posteriormente, escolher quais os tipos de equipamentos (baterias, painéis, controladores e inversores) que podem ser utilizados para o suprimento desta carga.

\subsubsection{Cálculo do consumo de cargas}

A planilha $1 C$ é utilizada para o cálculo do consumo de cargas, com base diária suportando sazonalidade semanal para cargas em corrente alternada, exclusivamente. Tal planilha também pode ser utilizada para o cálculo de cargas em corrente contínua, bastando apenas incluir os campos referentes a este tipo de carga. Porém, em virtude deste projeto só considerar cargas em corrente alternada, foram ocultados os campos referentes às cargas em corrente contínua. 
Recomenda-se preencher uma planilha para cada mês ou estação que possua uma demanda significativamente diferente, o que não é o caso em questão, pois assume-se que o comportamento das cargas é constante, pelo menos ao longo do período letivo. Sem contar que os meses analisados foram fevereiro e março de 2002.

Os parâmetros essenciais que devem ser observados na planilha $1 C$ são:

- A potência exigida pela carga;

- Os ciclos de serviço diário (tempo médio diário que a carga será utilizada) e semanal (número médio de dias que a carga será utilizada por semana);

- A tensão nominal do sistema: tensão típica em que operam as cargas que serão conectadas, normalmente em corrente contínua.

- Eficiência na conversão de potência: fator relacionado com a perda de energia que ocorre nos sistemas que utilizam inversores. Se um aparelho necessita de potência em uma tensão diferente da tensão fornecida pelo sistema, deve-se utilizar a eficiência de conversão do dispositivo. $O$ valor padrão de eficiência é de 0,80 quando se deseja converter CC para CA.

- Fator de eficiência da fiação: fator que se relaciona com a perda de energia causada pela fiação. O valor padrão para a eficiência da fiação é de 0,98.

- Fator de eficiência da bateria: é dado pela razão $A h_{\text {saida/ }} / A h_{\text {entrada. }}$ O valor padrão é de 0,95 .

O consumo médio da carga em Ah/dia é obtido a partir destes valores descritos anteriormente. Deve-se multiplicar a potência exigida pela carga pelos ciclos de serviço diário e semanal, e então dividir pela eficiência de conversão de potência e pela tensão nominal do sistema para obter o consumo.

Estimado o consumo total, deve-se dividi-lo pelas eficiências de fiação e da bateria para enfim obter a correção do consumo. 


\subsubsection{Determinação da corrente e do ângulo de inclinação do arranjo}

Para a determinação do ângulo de inclinação do arranjo fotovoltaico, utilizase a planilha $2 \boldsymbol{C}$ presente no Anexo $\boldsymbol{C}$. Adota-se o conceito de Sol Pleno descrito anteriormente para a obtenção da corrente de projeto.

Esta planilha é utilizada para avaliar três possibilidades de inclinação para o arranjo fotovoltaico: inclinação referente ao ângulo da latitude do local onde será instalado o sistema fotovoltaico e inclinações deste mesmo ângulo acrescido e subtraído de 15․ A aplicação desta planilha é útil para os casos em que a demanda de carga varia muito ao longo do ano.

Os principais parâmetros utilizados na planilha $2 C$ são:

- A carga corrigida (Ah/dia): este valor foi calculado na planilha 1C, e normalmente pode variar ao longo dos meses. Porém, a variação mensal só é considerada se a demanda não for a mesma de um mês para outro ao longo do ano. Quando se tem a mesma demanda ao longo do ano, a carga não apresenta variação.

- Corrente de projeto (A): Para selecionar qual o melhor ângulo de inclinação para o arranjo fotovoltaico, determina-se a maior corrente de projeto mensal para cada um dos ângulos e, em seguida, seleciona-se a menor corrente de projeto entre estas três possibilidades.

A corrente de projeto, para cada mês, é obtida pela razão entre o valor da carga corrigida (Ah/dia) e o valor de Sol pleno (h/dia).

\subsubsection{Dimensionamento do banco de baterias}

A planilha 3C, em anexo, indica quais são os parâmetros e procedimentos necessários para o dimensionamento de um banco de baterias. Os parâmetros que devem ser destacados são: 
- Os dias de armazenamento: deve-se escolher a quantidade de dias consecutivos que o sistema de armazenamento terá de atender à carga nos períodos em que o arranjo fotovoltaico não estiver gerando energia.

- Profundidade de descarga máxima: máxima descarga permitida para a bateria. 0 valor padrão para baterias de chumbo-ácido, que são as mais utilizadas, é de 0,8.

- Desconto por temperatura: fator que corrige a capacidade da bateria para baixas temperaturas, cujo valor padrão usado para o Brasil (país tropical) é 1 .

- Capacidade útil da bateria (Ah): valor que pode seguramente ser fornecido pelas baterias instaladas.

Multiplicando o valor do consumo das cargas, obtido da planilha $1 C$, pelos dias de armazenamento e, em seguida, dividindo pelo valor de profundidade de descarga máxima e pelo desconto por temperatura, obtém-se a capacidade necessária para a bateria. Dividindo o valor da capacidade necessária pela capacidade da bateria selecionada, obtida nas especificações do fabricante, tem-se a quantidade de baterias que devem ser conectadas em paralelo.

Quando se divide a tensão nominal do sistema pela tensão nominal da bateria, obtém-se o número de baterias que devem ser conectadas em série.

\subsubsection{Dimensionamento do arranjo fotovoltaico}

Todos os procedimentos para o dimensionamento do arranjo fotovoltaico se encontram na planilha $4 \boldsymbol{C}$ do Anexo $\boldsymbol{C}$. É importante ressaltar que as especificações dos módulos utilizadas são de painéis da Kyocera, mas podem ser utilizadas especificações de diversos outros tipos de painéis.

Os principais parâmetros utilizados em tal dimensionamento são:

- Corrente de projeto: o valor deste parâmetro é obtido na planilha $2 C$, quando feito o cálculo do melhor ângulo de inclinação.

- Fator de correção do módulo: fator de ajuste da corrente do módulo nas Condições Padrão de Teste (STC) para as condições de campo - acúmulo de poeira, perdas entre módulos mal conectados, degradação ao longo do tempo. 
O valor padrão para módulos do tipo cristalino é de 0,9 para as seguintes condições padrão de teste: Radiação de $1000 \mathrm{~W} / \mathrm{m}^{2}$, temperatura da célula de $25^{\circ} \mathrm{C}$ e massa de ar igual a 1,5.

- Corrente nominal (A) e tensão nominal $(V)$ do módulo: corrente e tensão obtidos junto às especificações do fabricante, para as condições padrão de teste (STC).

- Tensão do módulo para temperatura mais elevada (V): valor fornecido nas especificações do fabricante para a tensão do módulo, correspondente ao valor mais alto esperado para a temperatura de operação.

- Corrente de curto circuito do módulo $\left(\mathrm{I}_{\mathrm{sc}}\right)$ e tensão de circuito aberto $\left(\mathrm{V}_{\mathrm{OC}}\right)$ : valores obtidos nas especificações do fabricante para as condições padrão de teste.

O produto da corrente de projeto pelo fator de correção do módulo resulta na corrente de projeto corrigida, que dividida pela corrente nominal do módulo determina o número de painéis que devem ser conectados em paralelo.

Multiplicando a tensão nominal da bateria por uma fator de 1,2 e pela quantidade de baterias em série, obtém-se a tensão necessária para carregar as baterias que, dividida pela tensão do módulo para a temperatura mais elevada, resulta na quantidade de módulos que devem ser conectados em série.

Além do banco de baterias e dos módulos fotovoltaicos, os demais equipamentos que compõem o sistema também devem ser especificados, além da fiação (bitola dos condutores). As principais informações referentes a todos os elementos que compõem o sistema em questão, além das tabelas de dimensionamento dos cabos, se encontram no Anexo $D$. Os equipamentos do sistema instalado no SG 11 são os seguintes:

- Módulos Fotovoltaicos de silício cristalino Kyocera, modelo KC 45;

- Baterias seladas de níquel-cádmio Concorde Sun Xtender, modelo PVX 12105T;

- Controlador de carga ProStar-30;

- Inversor PowerStarUPG 400. 


\section{RESULTADOS}

Realizado o dimensionamento de um sistema fotovoltaico, procede-se para a instalação do sistema e análise do comportamento do mesmo. Neste capítulo, serão mostrados como estão instalados os equipamentos e como foi o desempenho do sistema, para verificação do dimensionamento.

\subsection{Instalação do sistema fotovoltaico}

Esta seção apresenta os procedimentos básicos que devem ser obedecidos para a instalação de um sistema fotovoltaico, além de descrever como foram realizadas as instalações do sistema em estudo. É importante ressaltar que devem ser utilizados os mesmos procedimentos de segurança pessoal e de equipamentos aplicados nas instalações elétricas convencionais.

\subsubsection{Painéis fotovoltaicos}

Um dos aspectos que deve ser observado antes da instalação dos painéis fotovoltaicos refere-se à localização dos mesmos. Certos critérios devem ser considerados para a obtenção da melhor localização:

- Identificação de objetos capazes de encobrir a luz do Sol (árvores, prédios, antenas). Este procedimento deve ser realizado para evitar a ocorrência de sombras nas horas de melhor insolação, usualmente entre 9 e 15 horas, principalmente nos dias mais curtos do ano, que são aqueles com sombras maiores.

- Análise da localização que possibilite melhor proteção contra atos de vandalismo e eventuais acidentes.

- Análise da relação custo-benefício entre a localização descrita anteriormente e a localização o mais próximo possível das cargas e baterias, que permite minimizar a queda de tensão nos fios.

O sistema instalado no SG 11 está localizado no telhado do mesmo, considerando os critérios descritos anteriormente. Buscou-se evitar quaisquer tipos 
Pequeno Porte

de acidentes e atos de vandalismo, além de que, atendeu-se a condição de manter o sistema próximo das baterias e das cargas. A fiação utiliza-se do menor percurso entre o sistema e as cargas (as lâmpadas se encontram no teto do andar superior do prédio).

Em relação à orientação dos módulos fotovoltaicos, deve-se observar a máxima captação de energia ao longo do ano. Duas devem ser as condições observadas:

- Primeiramente, em instalações localizadas no território brasileiro, os módulos devem estar orientados em direção ao Norte Verdadeiro, que nem sempre coincide com o Norte Magnético (indicado pela bússola). A diferença entre ambos denominase declinação magnética e deve ser aplicada à leitura da bússola.

A declinação magnética, para Brasília é de $18^{\circ}$ para o leste. Este ângulo deve ser adicionado à direção apontada pela bússola no sentido horário.

- A segunda condição refere-se ao ângulo de inclinação dos painéis fotovoltaicos.

Conforme descrito no capítulo anterior, existem diversas interpretações sobre qual deve ser este ângulo de inclinação. Em geral, a inclinação deve ser igual a latitude do local, mas nunca inferior a 15ำ, para favorecer a auto-limpeza dos painéis. Em alguns casos, afirma-se que a inclinação deve ser do valor da latitude acrescido de $15^{\circ}$, para otimizar o sistema obtendo maior uniformidade de energia solar ao longo do ano. O que se pode afirmar é que o ângulo de inclinação que maximiza a geração de energia varia com a época do ano e com a latitude do local onde o sistema será instalado. Então, para maximizar a energia gerada ao longo do ano, a inclinação deve se de 10 acima ou abaixo do valor da latitude do local.

Segundo a análise realizada anteriormente, o ângulo de inclinação do arranjo fotovoltaico instalado no SG 11 é de $31^{\circ}$. A figura 7.1ilustra a posição dos painéis instalados no telhado do SG 11. 


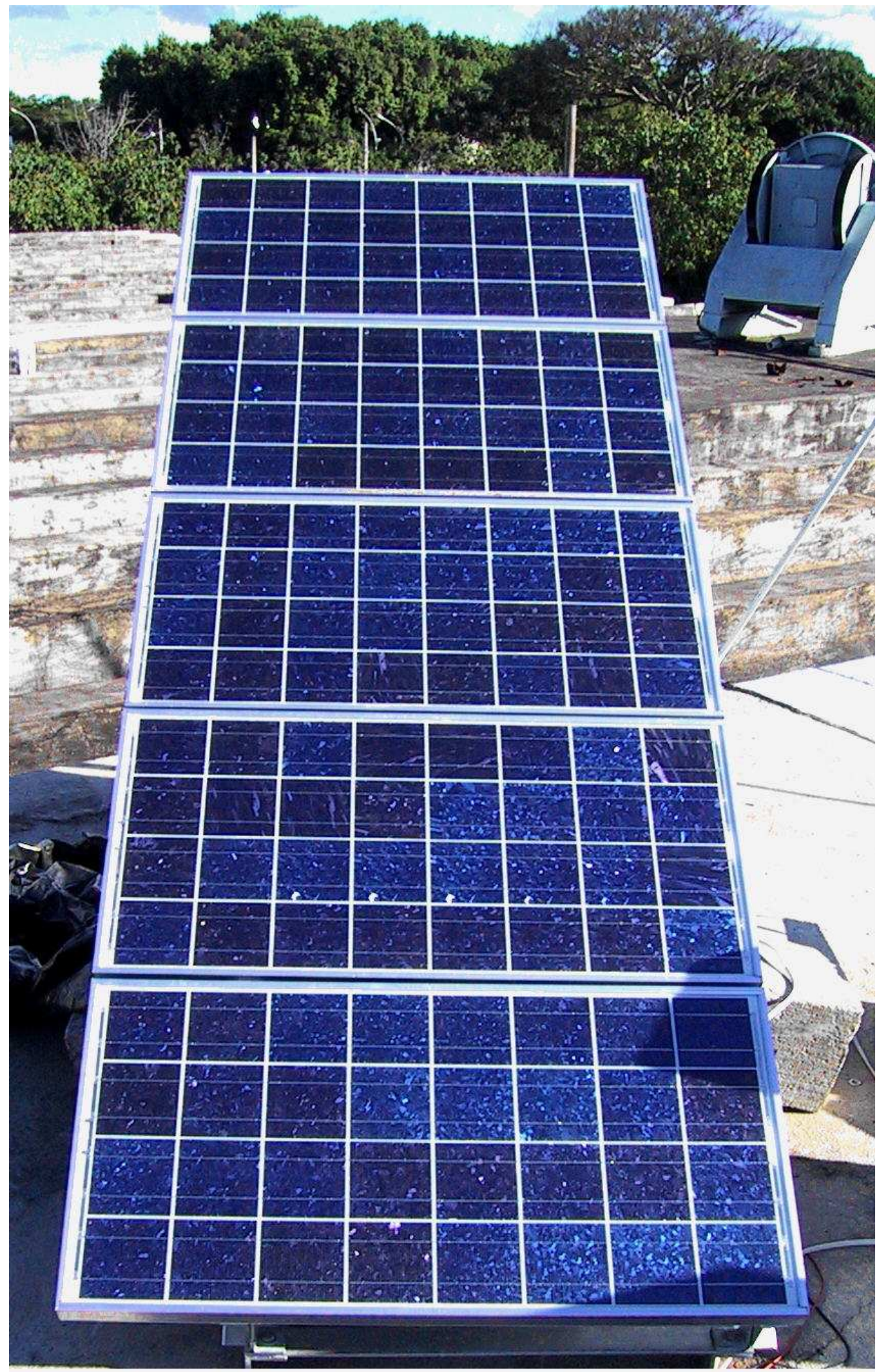

Figura 7.1 - Painéis solares fotovoltaicos instalados no telhado do SG 11 
Estudo de Sistemas Fotovoltaicos de

Pequeno Porte

\subsubsection{Baterias}

A instalação das baterias não apresenta dificuldades ou cuidados especiais, mas requer que alguns critérios técnicos e de segurança sejam respeitados:

- As baterias devem estar localizadas o mais próximo possível dos painéis para evitar perdas por queda de tensão. Além disso, não devem ser montadas diretamente sobre o piso de concreto para evitar o aumento da auto-descarga, elas devem estar isoladas do solo por um suporte de madeira ou outros materiais isolantes eletricamente e resistentes ao ácido.

- Como durante a recarga das baterias são produzidos gases hidrogênio e oxigênio, para evitar o risco de explosão, as baterias devem estar em locais ventilados e cuja temperatura varie entre $20^{\circ}$ e $25^{\circ}$. Se a temperatura diminuir muito, a capacidade da bateria diminui, e se a temperatura aumentar além dos 25ํㅡ a bateria pode envelhecer precocemente.

- Devem-se colocar as baterias em caixas de madeira ou polipropileno para garantir a segurança do usuário (restrição ao acesso), pois elas são compostos elétricos que podem produzir correntes e tensões elevadas, além de serem fabricados com produtos químicos perigosos, como o ácido sulfúrico.

O dimensionamento realizado anteriormente (planilha $3 C$ ) indicou a necessidade de duas baterias, conectadas em paralelo para atender o sistema de iluminação do SG 11, apesar de termos quatro baterias. Realizou-se, então a montagem das quatro baterias para que as duas restantes não ficassem inutilizadas.

A montagem de um banco de baterias com associação em paralelo deve ser efetuada com uma fiação cruzada, conforme a figura 7.2, de forma a equilibrar os níveis de tensão e corrente a que são submetidas as baterias. O número máximo de baterias em paralelo deve ser limitado entre 4 e 6 , sendo todas elas rigorosamente iguais. 
Estudo de Sistemas Fotovoltaicos de

Pequeno Porte

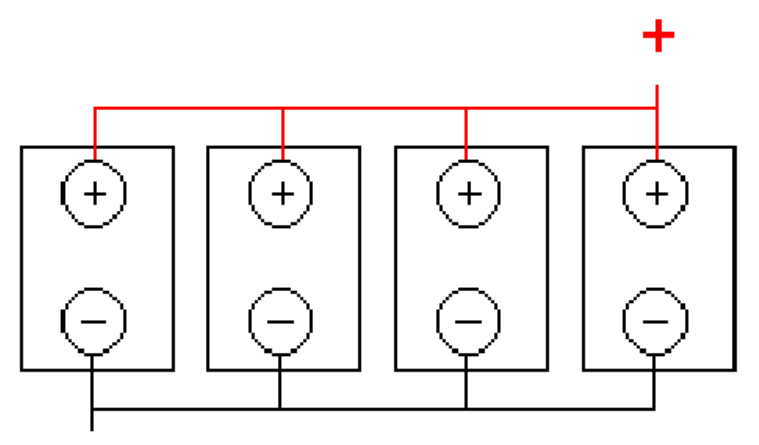

Figura 7.2 - Conexão de baterias em paralelo

A figura 7.3 mostra como estão conectadas duas das baterias que compõem o sistema instalado no SG 11.

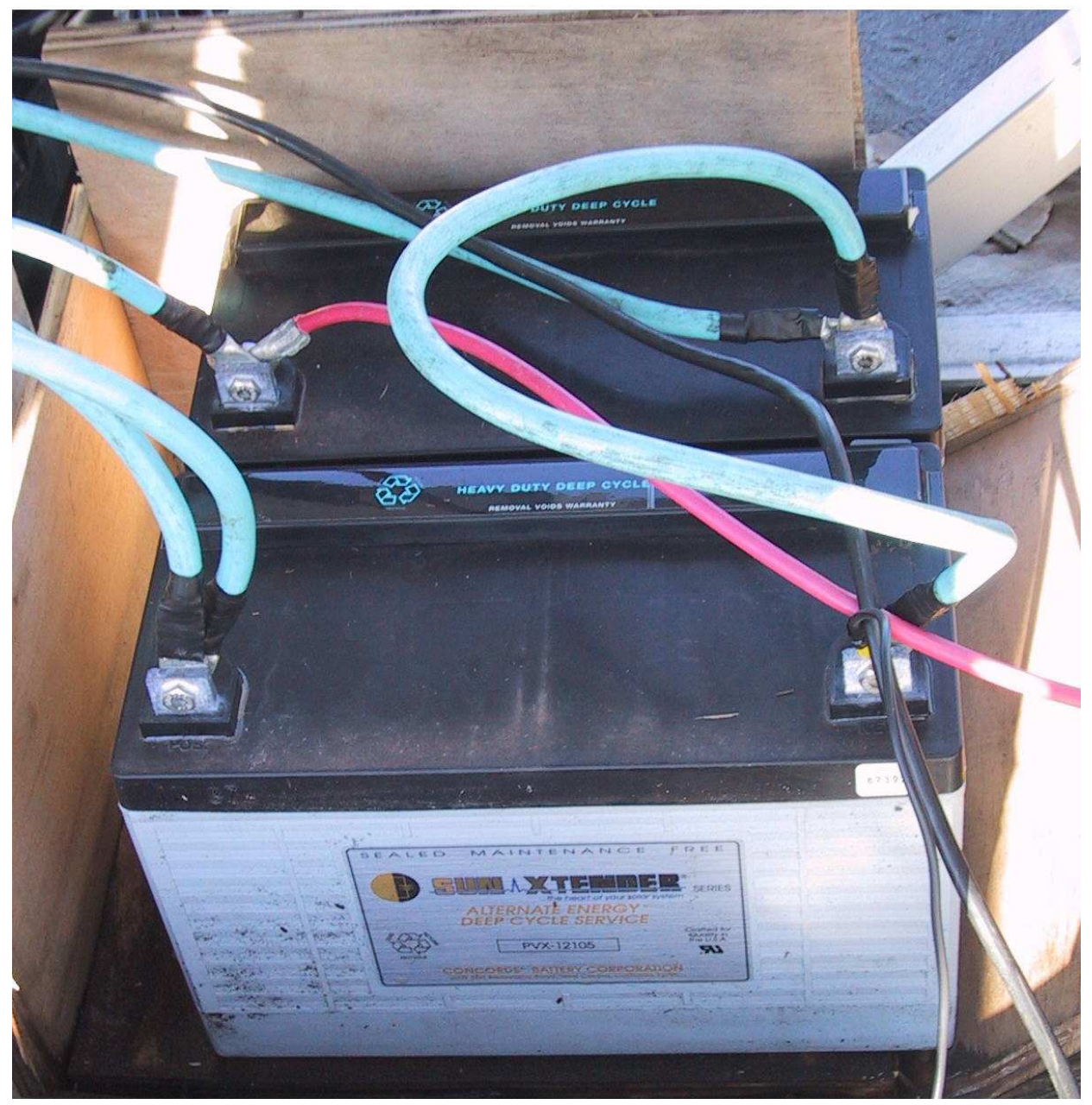

Figura 7.3 - Baterias que compõem o sistema fotovoltaico instalado no SG 11 


\subsubsection{Controles e Proteções}

Os controladores de carga e os inversores geralmente são instalados em uma caixa de controle, junto com chaves e fusíveis para o balanço do sistema (BOS).

Em virtude de os dispositivos eletrônicos serem muito sensíveis a temperatura e umidade elevadas, recomenda-se que a caixa de controle seja instalada em local seco e ventilado, o mais próximo possível dos módulos fotovoltaicos e isolado de fontes de ruídos eletrônicos. Tais equipamentos de controle não devem ser instalados no mesmo compartimento das baterias, pois elas podem produzir um ambiente corrosivo.

A figura 7.4 mostra como estão conectados o controlador de carga e o inversor do sistema do SG 11 dentro da caixa de controle.

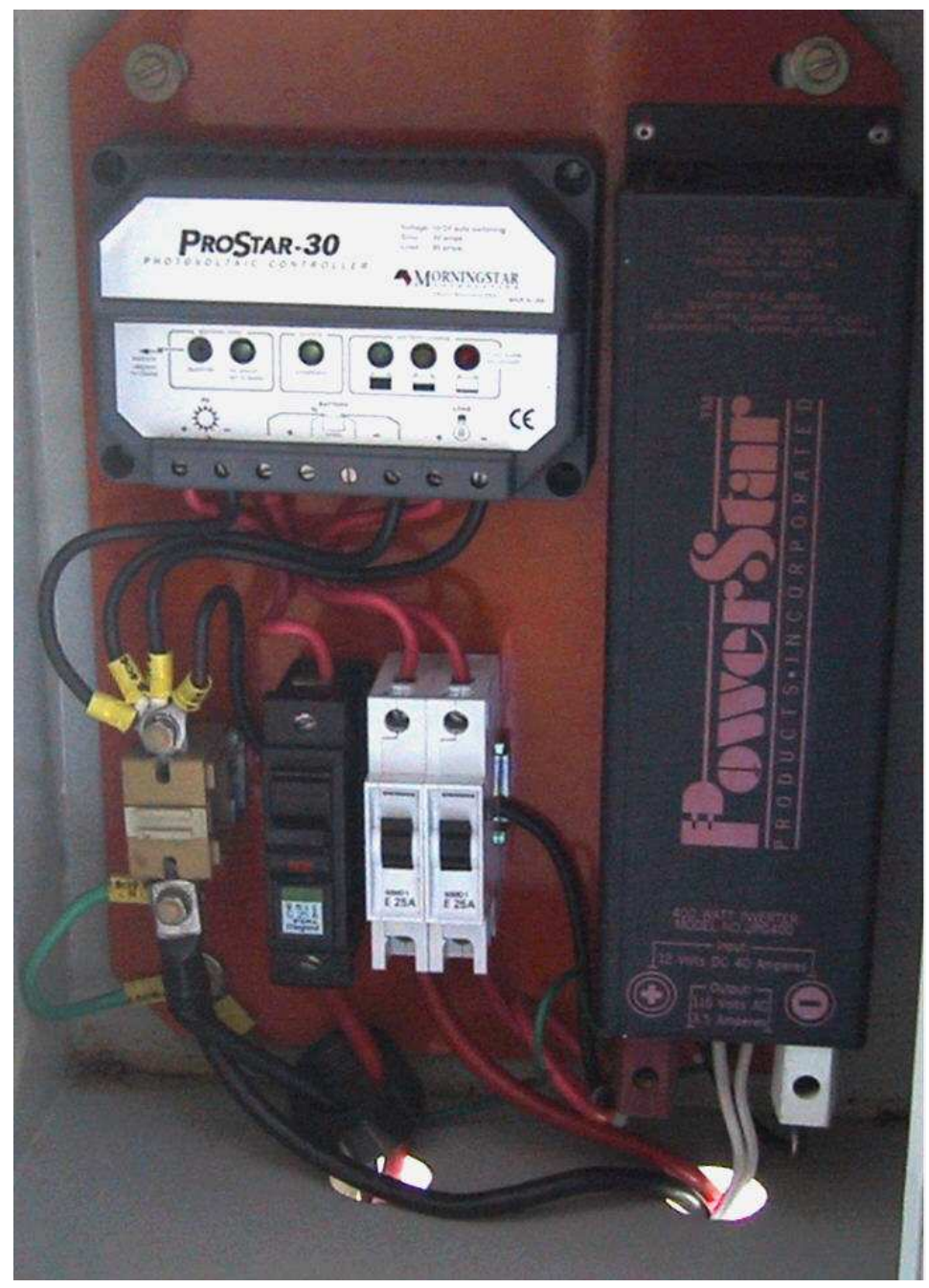


Figura 7.4 - Controlador de carga e inversor do sistema fotovoltaico do SG 11

\subsection{Análise do sistema fotovoltaico instalado no} SG 11

Após dimensionar e instalar o sistema fotovoltaico para iluminação do corredor superior do SG 11, foram necessárias algumas adaptações para que as cargas pudessem funcionar corretamente.

Em virtude de a geração ocorrer em corrente contínua, a uma tensão de 12 $\mathrm{V}$, e de existir um inversor para comutar esta tensão para $110 \mathrm{~V}$ em corrente alternada, seria necessário utilizar um transformador para atender cargas em $220 \mathrm{~V}$. Com a finalidade de observar se o sistema estava funcionando adequadamente, utilizou-se três lâmpadas incandescentes conectadas ao sistema.

Foram realizados testes com dois tipos de transformadores de aplicação geral (disponíveis comercialmente) - um de 700VA e outro de 1000VA - conectados na saída do inversor. Porém o sistema não comportou o uso destes transformadores, já que as lâmpadas se apagaram segundos depois de o sistema entrar em funcionamento. Observou-se que o inversor desarmou logo depois de o sistema ser posto em funcionamento.

A solução encontrada foi utilizar relés e reatores bivolt, que pudessem acender as lâmpadas, tanto em 110 V, como em 220 V. É importante ressaltar que, a utilização de reatores bivolt é necessária para que a carga possa estar conectada à rede elétrica convencional e permanecer funcionando quando o banco de baterias não estiver suficientemente carregado para alimentar tais cargas. A figura 7.5 ilustra o diagrama das conexões realizadas para o funcionamento das lâmpadas. 


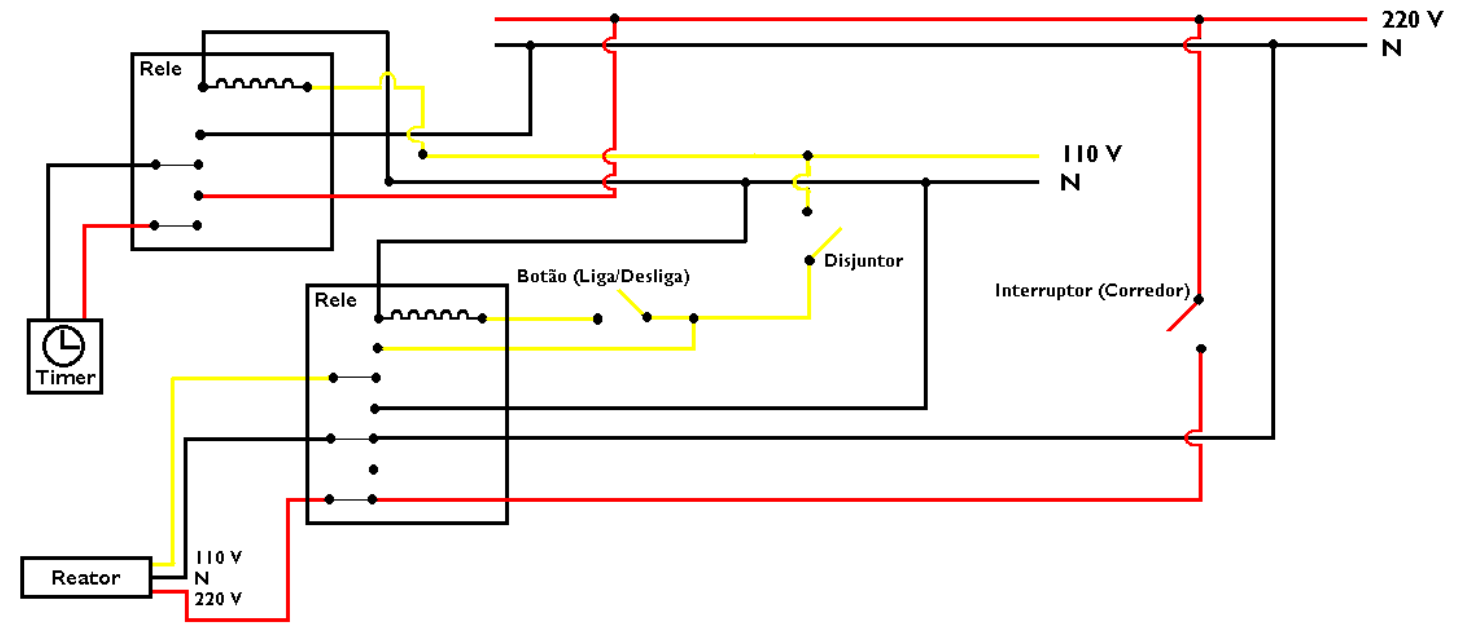

Figura 7.5 - Diagrama das ligações dos relés, reatores e do timer

Observando o diagrama, tem-se que os reatores (responsáveis pelo acionamento das lâmpadas) estão conectados a relés, que comutam os valores de tensão em $110 \mathrm{~V}$ ou $220 \mathrm{~V}$, para que haja o funcionamento das lâmpadas em ambos os níveis de tensão. Enquanto os bancos de bateria estiverem suficiente carregados, o inversor estará fornecendo $110 \mathrm{~V}$ para o sistema e as luminárias estarão funcionando, podendo ser desligadas apenas pelos botões de liga/desliga presentes em cada uma delas. Para tal configuração o interruptor presente no corredor não possui qualquer tipo de controle sobre as lâmpadas. Assim que as baterias são desconectadas do sistema por apresentarem baixos níveis de carga, o relé automaticamente comuta para o sistema convencional (220 V).

O timer foi utilizado para que se pudesse medir o tempo de funcionamento do sistema fotovoltaico, ou seja, enquanto as cargas estiverem sendo alimentadas em $110 \mathrm{~V}$, o timer está contando o tempo. Existe a necessidade de conectá-lo também à rede convencional $(220 \mathrm{~V})$, em virtude de se manter a freqüência em 60 $\mathrm{Hz}$.

Realizadas tais configurações, as cargas puderam ser alimentadas pelo sistema fotovoltaico, a assim pode-se observar o comportamento do mesmo. 


\subsubsection{Eficiência dos sistemas fotovoltaicos}

A eficiência dos sistemas fotovoltaicos depende da eficiência dos vários componentes do sistema, da forma como estão interligados e do tipo de carga que o sistema pretende alimentar.

Caso não seja fornecido pelo fabricante, o rendimento de um painel fotovoltaico pode ser obtido a partir da potência máxima $(\mathrm{Pp})$ - máxima potência entregue pelo painel em condições padrão de teste (radiação de $1 \mathrm{~kW} / \mathrm{m}^{2}$, temperatura de $25^{\circ} \mathrm{C}$ e massa de ar de 1,5$)$ - e da área útil do painel. Para o painel que está sendo utilizado no sistema instalado no SG 11, tem-se então:

$$
\mathrm{h}_{\mathrm{p}}=\frac{100^{*} \mathrm{Pp}}{\mathrm{A}}=\frac{100^{*} 45^{*} 10^{-3}}{573^{*} 10^{-3 *} 652^{*} 10^{-3}}=12 \%
$$

$\mathrm{h}_{\mathrm{p}}$ : rendimento do painel (\%)

Pp: potência de pico do painel $(\mathrm{kWp})$

A: área útil do painel $\left(\mathrm{m}^{2}\right)$

O valor acima não é o mesmo determinado pelo fabricante para o painel em questão. Segundo especificações do fabricante, a eficiência de conversão das células é acima de $14 \%$.

Para verificar o desempenho do arranjo fotovoltaico, recomenda-se medir a tensão de circuito-aberto e a corrente de curto-circuito. De posse de tais valores, pode-se calcular o real valor de potência de pico e de rendimento do painel. Ressalta-se que, pelo fato de a corrente de curto-circuito ser proporcional à intensidade solar, no momento do teste deve-se medir o nível de radiação solar, para que os valores obtidos possam ser comparados com os valores especificados pelo fabricante para a quantidade de radiação solar incidente. Além disso, deve-se levar em consideração que a temperatura real de operação normalmente é maior que $25^{\circ} \mathrm{C}$, o que resulta em uma tensão de circuito aberto menor que a especificada para as condições padrão de teste.

Para o sistema do SG 11, foram medidos apenas os valores de tensão e corrente entregues pelo arranjo fotovoltaico às baterias (e não diretamente às cargas), quando as cargas estavam conectadas ao sistema, e não os valores de 
tensão de circuito-aberto e corrente de curto-circuito. Mesmo porque, não é possível obter medidas de radiação solar, já que não se possui um instrumento capaz de realizar estas medidas, e as condições no momento das medições não estavam de acordo com as condições padrão de teste.

Os valores obtidos foram $14,5 \vee$ de tensão e 4,6 A de corrente do arranjo. Não foram medidos os valores fornecidos por cada painel, e sim pelo arranjo todo. Como os painéis estão conectados em paralelo, a tensão deve ser a mesma (14,5 V) para cada um deles. Já o valor de corrente pode ser dividido pela número de painéis (5), para que se possa obter o valor de corrente de cada um deles, que é de $0,92 \mathrm{~A}$.

Os valores fornecidos pelo fabricante são $15 \mathrm{~V}$ de tensão de máxima potência e 3 A de corrente de máxima potência. Comparando-se estes valores, observa-se que o valor da tensão está próximo do valor fornecido pelo fabricante, porém a corrente está muito abaixo do esperado. Um fator que pode justificar um valor tão baixo de corrente se relaciona com a limpeza dos painéis, pois painéis sujos fornecem menos corrente.

Além dos dados obtidos dos painéis, foram também realizadas algumas medidas referentes ao inversor, para assegurar a alimentação adequadas das cargas. Com o auxílio de um instrumento capaz de realizar medidas de potência em corrente alternada, considerando o fator de potência, foram obtidos os seguintes valores:

$$
\begin{aligned}
& \text { Tensão }=118 \mathrm{~V}_{\mathrm{CA}} \\
& \text { Corrente }=2,75 \mathrm{~A} \\
& \text { Potência }=109 \mathrm{~W}
\end{aligned}
$$

Fator de potência $(F P)=0,34$.

Observa-se que o fator de potência (FP) é muito baixo, o que diminui a potência fornecida para as cargas. Os parâmetros de entrada do inversor obtidos foram $13,5 V_{c c}$ e $4 A$, de tensão e corrente respectivamente, fornecidos pelo banco de baterias.

Mediu-se, também, os mesmos parâmetros das cargas que estavam sendo utilizadas e obteve-se, para uma lâmpada: 


$$
\begin{aligned}
& \text { Tensão }=119 \mathrm{~V}_{\mathrm{CA}} \\
& \text { Corrente }=766 \mathrm{~mA} \\
& \text { Potência }=29,5 \mathrm{~W}
\end{aligned}
$$

Fator de potência $(F P)=0,32$.

Os dados fornecidos pelo fabricante do reator são tensão de $127 \mathrm{~V}$, corrente de 0,47 A, potência de $36 \mathrm{~W}$ e fator de potência de 0,62. Comparando-se os valores obtidos com os valores fornecidos pelo fabricante, observa-se que o fator de potência medido também foi menor.

\subsubsection{Desempenho do sistema fotovoltaico}

A forma utilizada para analisar o desempenho do sistema fotovoltaico foi observar o comportamento das tensões no banco de baterias. Durante o tempo de análise - fevereiro e março de 2002 - foram realizadas medidas diárias de tensão nos terminais do banco de baterias para que se pudesse observar o comportamento do sistema. Foram obtidos os valores de tensão tanto de carga, quanto de descarga das baterias, e como resultado, foram plotados os gráficos das figuras 7.6 a 7.9. Esta avaliação de desempenho das baterias com seqüências de carga e descarga é um dos mais precisos testes que podem ser realizados.

Nos gráficos das figuras 7.6 e 7.7 estão os dados de carga das baterias, já nos gráficos das figuras 7.8 e 7.9 estão os valores de descarga das baterias. Entre 20 de fevereiro e 07 de março, observou-se o carregamento do banco de baterias e entre 11 e 28 de março, foram obtidos dados de descarga do banco de baterias.

\section{Figura 7.6 - Gráfico de carga das baterias}

\section{Figura 7.7 - Gráfico de carga das baterias}

Os gráficos mostrados nas figuras 7.6 e 7.7 indicam o comportamento das baterias durante alguns dias da semana, em determinado período do dia - na parte da manhã - em que as baterias estão se carregando. Estes gráficos indicam, também, que a partir de um certo valor de tensão, normalmente próximo de $12,5 \mathrm{~V}$, as cargas são ativadas. 
Pequeno Porte

Segundo os dados obtidos no manual de operação do controlador de carga, para o tipo de bateria que está sendo utilizado, a conexão das cargas é feita quando os níveis de tensão das baterias atingem 12,6 V. Comparando este valor com os valores obtidos nos gráficos, percebe-se a diferença (de 0,1 V) é aceitável.

Uma consideração importante deve ser feita em relação ao dia 26 de fevereiro, que foi um dia de chuva. Ao observar o gráfico da figura 7.7, percebe-se que o tempo de carregamento da baterias foi maior neste dia, comparado aos outros dias que foram dias ensolarados. Como as observações eram feitas em períodos de quatro a cinco horas por dia, no dia 26 de fevereiro, ao final de quatro horas, a tensão das baterias estava apenas em 12,2 V.

\section{Figura 7.8 - Gráfico de descarga das baterias}

\section{Figura 7.9 - Gráfico de descarga das baterias}

Segundo informações especificadas pelo fabricante do controlador de carga, as cargas devem ser desconectadas do sistema quando a tensão do banco de baterias for de 11,4 V. Analisando os gráficos das figuras 7.8 e 7.9, observa-se que, na maioria dos casos em que se pôde acompanhar a desconexão das baterias, os valores de tensão de desconexão das cargas estão entre 11,8 V e 11,9 V, valores acima dos especificados pelo fabricante do controlador. Este fato implica em diminuição considerável do tempo de funcionamento do sistema fotovoltaico, o que pode influenciar na validação dos procedimentos de dimensionamento.

Além da análise de carga e descarga das baterias, foi feito também um levantamento do tempo de funcionamento das cargas, para saber se o mesmo estava de acordo com o especificado no dimensionamento - 6 horas. A figura 7.10 mostra o gráfico plotado com os dados de tempo obtidos pelo timer. 


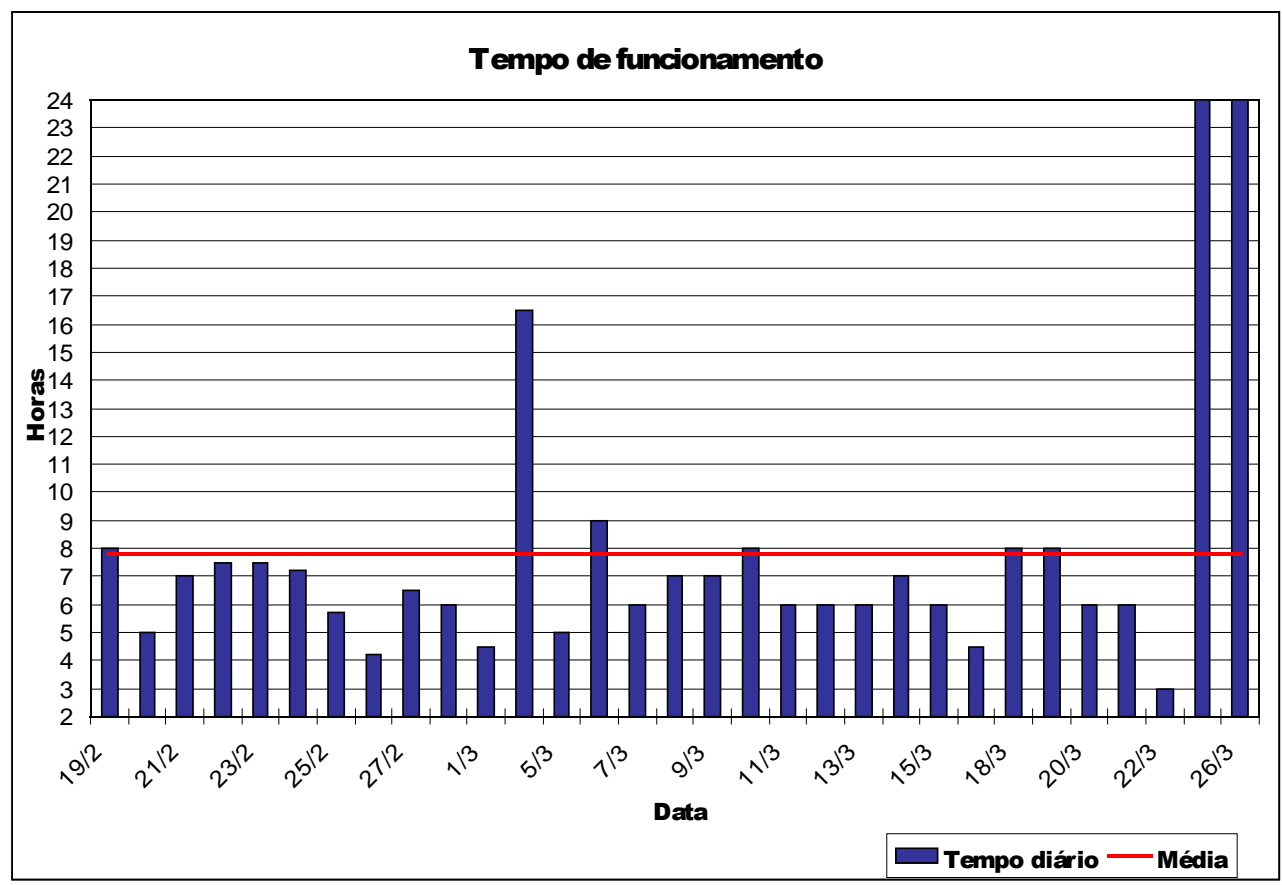

Figura 7.10 - Gráfico correspondente ao tempo de funcionamento do sistema fotovoltaico instalado no SG 11

Analisando os dados obtidos, calculou-se que o tempo médio de funcionamento do sistema fotovoltaico foi de 7,8 horas/dia. Nem todos os dias da semana foram utilizados para a contagem de tempo de funcionamento do sistema, em alguns finais de semana o sistema se manteve desligado (02 e 03, 16 e 17, 23 e 24 de março). Observa-se que no dia seguinte a estes finais de semana, o tempo de funcionamento do sistema foi superior ao normal, atingindo mais de 16 horas no dia 04 de março.

Os dias 25 e 26 de março apresentam um dado difícil de ser analisado, pois foram atípicos. Para ambos os dias, o sistema se manteve funcionando durante 24 horas, o que pode ser explicado pelo fato de que as lâmpadas foram desligadas ao final de um dia (após oito horas da noite) sem que as baterias fossem desconectadas do sistema. Ainda existia carga nas baterias, porém não haviam lâmpadas ligadas para consumir esta carga.

Ao multiplicar a hora média (7,8 horas) de funcionamento pela potência das lâmpadas (32 W), obtém-se a energia média diária, que é igual a 249,6 Wh.

Observa-se que, o sistema não atendeu as expectativas propostas pelo dimensionamento. O dimensionamento propõe que o sistema funcione por 6 horas 
Pequeno Porte

diárias, além de que as baterias devem atender as cargas por três dias consecutivos caso o arranjo não gere energia. Os dias analisados foram dias típicos de sol, consequentemente o arranjo fotovoltaico esteve em condições de gerar energia e suprir as cargas. Existem alguns dos componentes que podem ter comprometido 0 funcionamento adequado do sistema: as cargas - lâmpadas fluorescentes - e as baterias.

As lâmpadas utilizadas foram lâmpadas fluorescentes, que possuem um fator de potência que não foi considerado neste método de dimensionamento. As planilhas propostas não consideram este fator para o dimensionamento, o que pode influenciar no comportamento dos sistemas. Um dos motivos de não se considerar o fator de potência é o fato de tais planilhas serem basicamente utilizadas para dimensionar sistemas isolados e que, na maioria das vezes utilizam cargas simples e em corrente contínua. Uma análise apurada deve ser realizada para adaptar tal dimensionamento para os sistemas que funcionam nas localidades atendidas pela rede convencional e que podem ser utilizados juntamente com o sistema convencional, não só para sistemas isolados.

Um outro equipamento que influencia muito o comportamento deste sistema são as baterias, que devem armazenar a energia produzida pelo arranjo. Ao observar que o tempo de funcionamento não foi condizente com o tempo previsto, pode-se considerar que as baterias não estejam em seu funcionamento adequado. Como o sistema em questão já vinha sendo utilizado para testes e demonstrações, antes de ser instalado no SG 11, as baterias provavelmente já apresentam falhas capazes de influenciar na eficiência do sistema, não podendo satisfazer ás especificações necessárias. O ciclo de vida útil destas baterias pode estar no fim quando as células são capazes de fornecer apenas $80 \%$ de sua capacidade nominal.

Existem ainda importantes testes que devem ser realizados para aperfeiçoar o método de dimensionamento de sistemas de pequeno porte, a fim de que se possa atender quaisquer tipos de cargas possíveis. É interessante que tais métodos se apliquem também às cargas convencionais, considerando o comportamento diferenciado de todas elas. 


\section{CONClusões}

O desenvolvimento das fontes alternativas de energia tem sido considerável no Brasil, principalmente pela existência de localidades não atendidas pela rede elétrica convencional. Economicamente, utilizar energia eólica e energia fotovoltaica nestas localidades é mais vantajoso do que estender a rede elétrica, por isso a utilização em larga escala deste tipo fonte de energia. Além disso, o esgotamento de novos potenciais a partir das fontes já existentes no Brasil (energia hidroelétrica, por exemplo) contribuiu para que, tanto a energia eólica quanto a energia fotovoltaica, apresentassem avanços consideráveis na fabricação dos equipamentos utilizados. As células a combustível ainda não possuem aplicações em larga escala, porém resultados satisfatórios estão sendo obtidos a partir de testes realizados em alguns estados brasileiros.

A energia solar fotovoltaica, que antes era considerada experimental, cara e complicada, atualmente já se tornou eficiente, confiável e acessível, pois o dimensionamento dos sistemas fotovoltaicos tem sido realizado adequadamente. Certamente, para localidades próximas da rede elétrica, é mais vantajoso, em função da relação custo/benefício, estender a rede elétrica até o local. E por enquanto, esta fonte de energia não é competitiva economicamente para sua aplicação nas localidades atendidas pela rede elétrica convencional. Entretanto, a mesma já pode ser vista como complemento do suprimento de energia.

O dimensionamento de um sistema fotovoltaico deve ser realizado de forma eficaz, pois esta é a etapa principal no desenvolvimento de um projeto envolvendo energia solar fotovoltaica. As planilhas de dimensionamento aqui desenvolvidas podem ser consideradas uma excelente ferramenta para dimensionamento de sistemas de pequeno porte, seja para o suprimento de cargas em corrente contínua ou em corrente alternada. Apesar de que, algumas condições ainda devem ser analisadas para aperfeiçoar este método de dimensionamento, pois sua utilização ainda é bastante limitada para sistemas com cargas em corrente alternada, já que a 
Pequeno Porte

maioria dos sistemas de pequeno porte caracteriza-se pela utilização de cargas em corrente contínua.

Analisando o desempenho do sistema que foi instalado no SG 11, comprova-se que este método de dimensionamento pode ser aplicado. Para complementar este método de dimensionamento, é importante analisar detalhadamente os tipos de lâmpadas que se pretende utilizar e o comportamento dos inversores e das baterias, pois ainda existem perdas consideráveis que podem comprometer a eficiência do sistema. Deve-se, também, criar um banco de dados que contenha as informações importantes dos diferentes fabricantes dos equipamentos que devem compor um sistema fotovoltaico. Este banco de dados pode ser útil na escolha dos equipamentos que melhora atendam aos diversos tipos de sistemas que podem ser dimensionados.

Com relação ao sistema utilizado, é importante ressaltar que existem diversas formas de otimizá-lo, no sentido de melhorar a aplicação a que ele foi destinado, para que se possa analisar a viabilidade de investimento neste tipo de sistema. Se forem utilizadas lâmpadas compactas e sensores de presença, as perdas podem ser minimizadas e este sistema poderá ser capaz de suprir a iluminação de todo o prédio do SG 11. 


\section{REFERÊNCIAS BIBLIOGRÁFICAS}

[1] Colle, S. \& Pereira, E. B., "Atlas de Irradiação Solar do Brasil”, Laboratório de Energia Solar - LABSOLAR/EMC/UFSC, Instituto Nacional de Pesquisas Espaciais - INPE e Instituto Nacional de Meteorologia - INMET, Brasília - DF, Outubro de 1998.

[2] Centro de Referência para Energia Solar e Eólica Sergio de Salvo Brito CRESESB, "Energia Solar - Princípios e Aplicações".

[3] Grupo de Trabalho de Energia Solar - GTES, "Manual de Engenharia para Sistemas Fotovoltaicos" - CEPEL - CRESESB.

[4] Montenegro, A. A., "Fontes Não-Convencionais de Energia - As Tecnologias

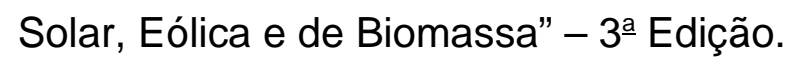

[5] Tiba, C., Fraidenraich, N. \& Barbosa, E. M. de S., "Instalação de Sistemas Fotovoltaicos para Residências Rurais e Bombeamento de Água", Versão 2.0, Novembro de 1998.

[6] Centro de Referência para Energia Solar e Eólica Sergio de Salvo Brito CRESESB, "Energia Solar e Eólica no Brasil - Projetos Implementados".

[7] Centro de Referência para Energia Solar e Eólica Sergio de Salvo Brito CRESESB, "Energia Eólica - Princípios e Aplicações”.

[8] http://www.aondevamos.eng.br

[9] http://www.eolica.com.br

[10] http://www.cresesb.cepel.br

[11] http://www.eletrocell.com.br

[12] http://www.copel.com.br

[13] http://www.geste.mecanica.ufrgs.br 


\section{ANEXOS}

ANEXO A - Mapas de Irradiação Mensal e Variabilidade Diária

ANEXO B - Legislação

ANEXO C - Planilha de Dimensionamento

ANEXO D - Especificações de

Componentes 